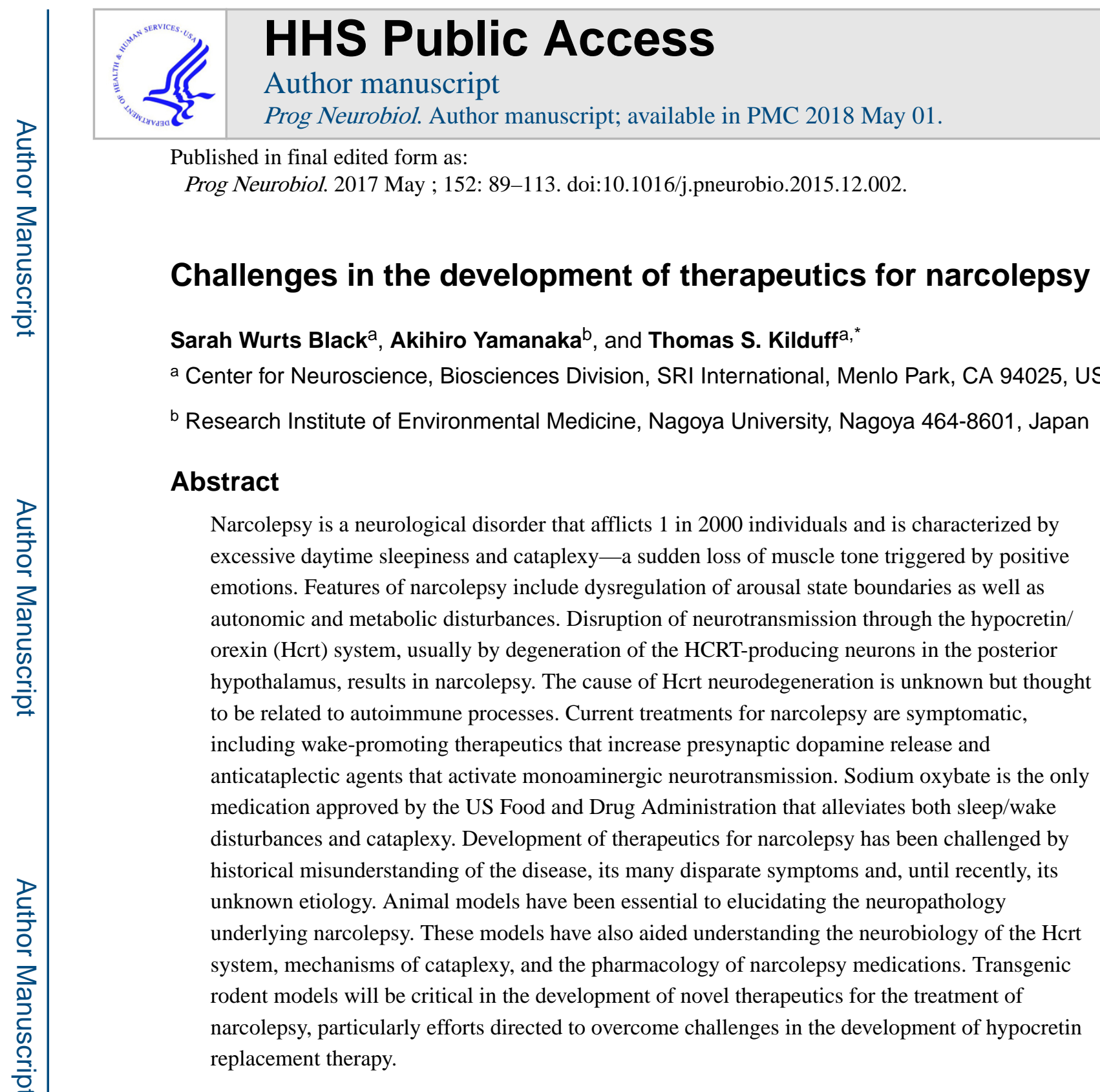

\title{
Keywords
}

Narcolepsy; Cataplexy; Orexin; Hypocretin; Neurodegeneration; Animal models

\section{Overview of narcolepsy}

\subsection{History}

The neurological disorder narcolepsy began with descriptions of patients who experienced attacks of muscle weakness with retained consciousness after excitation (Westphal, 1877)

\footnotetext{
* Corresponding author at: Center for Neuroscience, Biosciences Division, SRI International, 333 Ravenswood Avenue, Menlo Park, CA 94025, USA. Tel.: +1 650859 5509. thomas.kilduff@ sri.com (T.S. Kilduff).

Disclosure statement

Within the last 12 months, Dr. Kilduff and Dr. Black have received research support from Hoffmann La-Roche and Dr. Kilduff has received honoraria from Merck Pharmaceuticals and Pfizer.
} 
and the frequent, urgent need to sleep (Gélineau, 1880; Schenck et al., 2007). The term "narcolepsy" (literally "seized by somnolence") was coined by Gelineau and was described over one hundred years ago as a syndrome with many disparate features that seemed to defy reconciliation with a unified mechanism of etiology. Overwhelming sleepiness, emotionallytriggered muscle paralysis, onset of sleep attacks possibly associated with head trauma, sleep attacks during physical activity, nighttime sleeplessness, hallucinations, mental sluggishness and obesity were all described in these early reports. The attacks of paralysis were considered distinct from epilepsy because they were not accompanied by loss of consciousness, sensation was maintained, and neither tonic convulsions nor clonic movement were observed. These episodes were first characterized by Löwenfeld (Löwenfeld, 1902) but eventually termed "cataplexy" (literally "struck down as if stupefied") by Henneberg and Adie in the early 20th century (Guilleminault et al., 2007) to refer to sudden, emotionally-triggered bilateral loss of muscle tone.

\subsection{Clinical features}

1.2.1. The narcolepsy tetrad-The symptoms of narcolepsy were first organized into the classic tetrad to aid diagnosis (Yoss and Daly, 1957) and include:

- $\quad$ Excessive daytime sleepiness (EDS): sudden or persistent need to sleep during the day, independent of the amount or quality of previous nighttime sleep;

- $\quad$ cataplexy: sudden loss of muscle tone, usually triggered by positive, rather than negative, emotional stimuli (Anic-Labat et al., 1999);

- $\quad$ hypnogogic hallucinations: unreal, vivid auditory or visual perceptions at sleep onset;

- $\quad$ sleep paralysis: temporary inability to move while falling asleep or awakening.

Of these symptoms, only cataplexy is unique to narcolepsy-the others can occur in people without narcolepsy, for example, in instances of severe sleep deprivation (Guilleminault and Cao, 2011). In addition, not all of these symptoms are present in all narcoleptic individuals. Cataplexy, while pathognomonic of narcolepsy, only occurs in 60-70\% of narcoleptic patients (Bassetti and Aldrich, 1996) and, consequently, a distinction is made between diagnosis of narcoleptic patients with and without cataplexy (see Section 1.2.2). Beyond the classic tetrad, other features are now well acknowledged to contribute to the symptomatology of narcolepsy. Many of these features have been discovered through advances in basic sleep research over the last 50 years.

1.2.2. Non-tetrad symptoms: arousal state instability-The discovery of rapid eye movement (REM) sleep as a distinct sleep state characterized by activated EEG, muscle atonia, bursts of eye movements, and vivid dreaming (Aserinsky and Kleitman, 1953; Dement and Kleitman, 1957; Jouvet et al., 1959) heralded a new understanding of the narcolepsy syndrome. Subsequent research revealed that patients with narcolepsy entered REM sleep sooner than the typical 90 min interval after sleep onset that is observed in nonnarcoleptic controls (Rechtschaffen et al., 1963). Because these sleep-onset REM periods (SOREMPs) persisted during daytime naps (Dement et al., 1966), narcolepsy came to be viewed as a disorder of REM sleep timing. Intrusions of inappropriately timed dream 
imagery and muscle atonia of REM sleep were also thought to underlie the hypnogogic hallucinations and sleep paralysis experienced by patients with narcolepsy. Cataplexy came to be viewed as an initiation of REM sleep atonia during wakefulness-a hypothesis corroborated by the finding that only patients who experienced cataplexy also exhibited SOREMPs (Dement et al., 1966). These observations led to the implementation of the Multiple Sleep Latency Test (MSLT) to detect SOREMPs, and to objectively measure daytime sleepiness as an aid in the diagnosis of narcolepsy (Mitler et al., 1979; Richardson et al., 1978). In the MSLT, patients are provided a series of 4-6 nap opportunities at $2 \mathrm{~h}$ intervals that begin $2 \mathrm{~h}$ after the onset of wakefulness following a night of standard polysomnography. During the nap opportunities, mean sleep latency within 8 min and REM onset within 15 min (a SOREMP) in at least 2 naps was considered pathologic (Mathis and Hess, 2007). Recently, the diagnostic criteria for narcolepsy have changed such that a SOREMP during polysomnographic monitoring on the night prior to the MSLT can count as one of the two or more SOREMPS required for diagnosis (Eichler, 2014). Thus, three of the tetrad symptoms (cataplexy, hypnogogic hallucinations and sleep paralysis) appeared to be linked to a REM sleep abnormality in narcolepsy, but EDS did not fit this paradigm.

As the timing of sleep and wakefulness across the $24 \mathrm{~h}$ day/night cycle became recognized as due to interaction between the circadian timekeeping system and a sleep homeostatic mechanism (Borbely et al., 1984; Daan et al., 1984; Edgar et al., 1993), the pathological sleepiness in narcolepsy was also examined in these terms. Patients with narcolepsy not only have difficulty staying awake during the day, they also sleep poorly at night (Roth et al., 2013). Could the EDS of narcolepsy be a compensatory response to lost night time sleep? Slow wave activity during NREM sleep (EEG spectral power in the $0.75-4.5 \mathrm{~Hz}$ frequency band), an index of homeostatic sleep drive, was shown in narcoleptics to increase after experimentally-induced sleep deprivation and to decrease during recovery sleep, which revealed that homeostatic regulation was operative (Tafti et al., 1992). Despite shorter latencies from bedtime to sleep onset, patients with narcolepsy indicate that they experience insomnia more frequently than controls (Parkes et al., 1998). These self-reports have been supported by objective polysomnography in which frequent nocturnal awakenings and reduced REM sleep latency are thought to contribute to fragmented nighttime sleep in narcolepsy (Harsh et al., 2000). Despite the large sample size in this study, however, the relationship between disrupted nighttime sleep and sleepiness the following day was found to be weak and thus does not explain the EDS of narcolepsy (Harsh et al., 2000). In addition, the defined, but attenuated, distribution of sleep, wake, and sleepiness across the $24 \mathrm{~h}$ day/ night cycle in patients with narcolepsy has been interpreted to indicate an intact circadian timekeeping system (Broughton et al., 1988; Dantz et al., 1994). Thus, neither dysfunctional sleep homeostatic mechanisms nor abnormal circa-dian processes fully explain the pattern of fragmented arousal states.

The observations that SOREMPs, the extent of nocturnal awakening, and EDS strongly correlate with cataplexy (Harsh et al., 2000) foreshadowed the current view that narcolepsy is best described as a disorder of arousal state instability. It has now been firmly established that the loss of arousal state boundary control, first described by Broughton et al. (1986), arises from the loss of the hypothalamic neuropeptide hypocretin-1 (HCRT1), also known as orexin (see Section 2.2 and Section 2.4). The 3rd Edition of the International Classification 
of Sleep Disorders, (Eichler, 2014) formalized the distinction of narcolepsy with loss of HCRT1 (which usually presents with cataplexy) as "narcolepsy type 1", and without HCRT1 loss or cataplexy as "narcolepsy type 2." Narcolepsy type 1 was intended to capture patients who clearly have insufficient HCRT1 levels but may not yet manifest cataplexy, since a third of patients with low HCRT1 do not develop cataplexy until 15 years after the onset of EDS (Andlauer et al., 2012). Classification of narcolepsy type 1 requires EDS, a positive score on the MSLT, and either cataplexy or, if cataplexy is absent, a low concentration of cerebrospinal fluid (CSF) HCRT1 $(<110 \mathrm{pg} / \mathrm{ml}$, if using a standard reference) that is $1 / 3$ of normal levels (Baumann et al., 2014). Narcolepsy type 2 also requires EDS and a positive score on the MSLT, and is diagnosed based on exclusion of narcolepsy type 1 and differentiation from hypersomnia by the presence of sleep paralysis and hallucinations. A SOREMP on polysomnography the night preceding the MSLT may substitute for one of the $\geq 2$ SOREMPs on the MSLT that is typically required for the diagnosis of narcolepsy type 1 and type 2 . These new diagnostic criteria and the classification of narcolepsy types underscore the move away from classic tetrad symptomatology to a more refined understanding based on the etiology of the disease.

1.2.3. Metabolic and autonomic abnormalities-A renewed interest in the metabolic abnormalities noted anecdotally in narcoleptic patients resulted from the discovery of the role of HCRT loss in narcolepsy (see Section 2.2 and Section 2.4) and identification of the concomitant role of HCRT in energy homeostasis (Funato et al., 2009; Hara et al., 2001; Yamanaka et al., 2003). Narcolepsy has consistently found to be associated with obesity or increased body mass index (BMI) that does not appear to be secondary to daytime inactivity from EDS or medication (Chabas et al., 2007; Dahmen et al., 2001; Heier et al., 2011; Kok et al., 2003; Nishino et al., 2001; Poli et al., 2009; Schuld et al., 2002). Although the obesity has been clearly linked to low cerebrospinal fluid (CSF) HCRT1 levels (Heier et al., 2011; Nishino et al., 2001; Poli et al., 2009) and abdominal fat deposits (Kok et al., 2003; Poli et al., 2009), the cause of the BMI increase in narcolepsy has been challenging to parse. Binge eating, irresistible food cravings, and sleep-related eating disorder have been reported in approximately a quarter of narcoleptic patients (Fortuyn et al., 2008; Palaia et al., 2011), but this population also has reduced daily caloric intake compared to healthy controls (Chabas et al., 2007; Lammers et al., 1996). Like other overweight people, patients with narcolepsy who are obese tend to have lower resting metabolic rates (Chabas et al., 2007). The higher prevalence of eating disorders and the specificity of reduced basal metabolism to narcolepsy has been challenged in studies that employed BMI-matched controls, and have led to the hypotheses that obesity in narcolepsy could be due to changes in BMI set point or to reduced sympathetic tone (Dahmen et al., 2008, 2009; Fronczek et al., 2008a). Early reports of reduced leptin, a hormone that signals energy deficiency (Kok et al., 2002; Nishino et al., 2001; Schuld et al., 2000) or impaired glucose metabolism as in type 2 diabetes mellitus (Honda et al., 1986) have not been corroborated by studies of narcolepsy patients that have employed more rigorous methodology (Beitinger et al., 2012; Donjacour et al., 2014, 2013; Ohayon, 2013). However, a recent study of narcolepsy type 1 patients sampled close to disease onset found a positive correlation between CSF leptin levels and BMI; subjects with long disease duration and low CSF HCRT1 levels had higher leptin levels and BMI (Kornum 
et al., 2015). Surprisingly, patients with narcolepsy have been shown to be more sensitive to insulin in peripheral tissues (Donjacour et al., 2014).

Autonomic disturbances in narcolepsy have been reported, but still remain poorly understood. Whether the autonomic changes are directly due to the loss of HCRTs or are secondary to the ensuing sleep/wake fragmentation has been difficult to ascertain, particularly because Hcrt neurons influence both sympathetic and parasympathetic outflows (Plazzi et al., 2011; van den Pol, 1999). Some studies have indicated reduced sympathetic tone in narcolepsy, as revealed by attenuated cardiovascular reflexes (Sachs and Kaijser, 1982) or increased variability in heart rate and blood pressure (Fronczek et al., 2008a). Other studies in which heart rate variability was measured in patients with narcolepsy have demonstrated normal reduction in sympathetic outflow during sleep, but reduced parasympathetic tone during wakefulness (Ferini-Strambi et al., 1997) or enhanced sympathetic activity during orthostatic stress (Grimaldi et al., 2010b). Baseline heart rate has also been reported to be elevated in narcolepsy (Grimaldi et al., 2012; Sorensen et al., 2013). The normal responses of increased heart rate in relation to arousals from sleep and decreased blood pressure during sleep have been shown to be blunted in narcolepsy with cataplexy (Dauvilliers et al., 2012; Grimaldi et al., 2012), particularly in those patients with low or absent HCRT1, even compared to narcolepsy patients with normal HCRT1 levels (Sorensen et al., 2013). Together, these results support the hypothesis that HCRT insufficiency, concomitant with altered sleep architecture, leads to increased sympathetic activation. However, this hypothesis appears to be refuted by a recent study in which a correlation was found between HCRT1 level, heart rate and resting muscle sympathetic nerve activity as measured by direct microneurographic monitoring (Donadio et al., 2014). Perhaps these opposing results could be explained by the possibility that autonomic changes near disease onset differ from autonomic responses that develop over time to compensate for the initial changes, as has been hypothesized for thermoregulatory changes in narcolepsy (Black et al., 2013).

There is also evidence for altered temperature regulation in both human narcoleptics and animal models. Although a circadian rhythm of core body temperature $\left(T_{\mathrm{b}}\right)$ was clearly evident in human narcoleptics (Grimaldi et al., 2010a), nighttime $T_{\mathrm{b}}$ levels were elevated relative to controls (Mosko et al., 1983; Pollak and Wagner, 1994). Whether this is a cause or a consequence of disrupted nocturnal sleep in narcoleptics was unclear. Human narcoleptics also have a larger distal-to-proximal skin temperature gradient during wakefulness and, when asleep, maintain elevated distal skin temperature whereas proximal skin temperature increases to normal levels (Fronczek et al., 2006). Proximal skin warming in narcoleptic patients significantly suppressed nocturnal wakefulness and enhanced slow wave sleep whereas distal skin warming disrupted nocturnal sleep (Fronczek et al., 2008b). These observations are consistent with the concept that the Hcrt system is a key determinant of overall energy expenditure and, thus, body weight regulation.

The normal decline in $T_{\mathrm{b}}$ at sleep onset is also blunted in Hcrt-deficient mice; these mice also have normal $T_{\mathrm{b}}$ levels during wakefulness despite exhibiting less locomotor activity (Mochizuki et al., 2006). Similar results were also observed in orexin/ataxin-3 mice in which Hcrt neurons are chronically lost after birth (Black et al., 2013). In this study, the number of 
remaining Hcrt neurons in the transgenic mice positively correlated with the $T_{\mathrm{b}}$ change from wakefulness to NREM and REM sleep. Together, these results imply a role for the Hcrt system in either activation of heat loss mechanisms or, alternatively, loss of the HCRTs may result in compensatory elevated activity in other thermogenic systems. In contrast to chronic HCRT deficiency, acute disruption of Hcrt signaling with the dual HCRT receptor antagonist almorexant decreased $T_{\mathrm{b}}$ in wild type mice. These observations led to the hypothesis that at the onset of narcolepsy, early disruption of Hcrt signaling may reduce thermogenesis; then as more Hcrt neurons are lost, the ensuing hypothermia may activate compensatory heat conservation mechanisms (Black et al., 2013). Hypocretin neurons directly innervate the rostral raphe pallidus, site of sympathetic premotor neurons that innervate brown adipose tissue (BAT), thereby providing a neural pathway for elevating thermogenesis (Tupone et al., 2011). Hypocretin-deficient mice also exhibit impaired BAT differentiation (Sellayah et al., 2011). Hypocretin deficiency in narcolepsy could thus both increase the risk of obesity and the metabolic syndrome (Poli et al., 2009), while augmented activity in this system could contribute to a lean phenotype (Funato et al., 2009).

\subsection{Prevalence and risk factors}

Narcolepsy occurs in North America and Europe with a prevalence of $0.03-0.05 \%$ (Ohayon et al., 2002; Silber et al., 2002). Geographic differences clearly occur; in Japan, the prevalence may be as high as $0.18 \%$ (Honda, 1979; Tashiro et al., 1992) whereas cases are rarely reported in Israel (Lavie and Peled, 1987). As of 2002, the incidence rate was determined to be 1.37/100,000 new cases per year (Silber et al., 2002) with a bimodal distribution of age of onset with peaks at about 15 and 35 years of age (Dauvilliers et al., 2001). The proportion of narcolepsy cases in epidemiology studies that could be classified as narcolepsy type 1 or type 2 is currently unknown (Baumann et al., 2014). The average time to diagnosis from symptom onset (usually EDS appears first) has usually been reported to take longer than 10 years, but the time lag may diminish with improved awareness of the disorder (Thorpy and Krieger, 2014). Diagnostic delay is longer in women than men and is associated with higher body mass index (Luca et al., 2013). A retrospective study indicated that about half of narcoleptic patients report symptom onset prior to 15 years of age and, in China, 70\% had onset before age 10 (Han et al., 2011). The delay in diagnosis is greatly reduced when disease onset is in childhood (Nevsimalova, 2009) or when cataplexy presents as the first symptom or with high frequency (Luca et al., 2013). Only 1-2\% of first degree relatives share narcolepsy diagnoses, which represents a 10-40× increased risk factor compared to the general population (Mignot, 1998). Monozygotic twins that have narcolepsy with cataplexy are only 25-30\% concordant for the disorder (Mignot, 1997). While this evidence supports a role for environmental factors to contribute to narcolepsy onset, genetic predisposition is clearly important.

Risk factors for narcolepsy can be found in genes that encode the major histocompatibility complex proteins, also known as human leukocyte antigen (HLA) genes. Narcolepsy is highly associated with HLA class II polymorphisms in the closely linked loci DQB1*06:02 and DQA1*01:02 that together form the DQ0602 heterodimer (Juji et al., 1984; Matsuki et al., 1992; Mignot et al., 1994a). Almost all narcolepsy with cataplexy patients (82-99\%) are carriers of DQB $1 * 06: 02$ while only $12-38 \%$ of non-narcoleptic individuals carry this allele 
(Mignot et al., 1997, 2001). Full length exome sequencing (Tafti et al., 2014) has indicated the DQB $1 * 0602$ allele is not mutated in narcolepsy and, thus, is only a susceptibility factor in the disorder. The susceptibility risk for narcolepsy is two-fold in individuals that are homozygous for DQB1*06:02 compared to heterozygous carriers (Pelin et al., 1998). The largest genome-wide association study to date estimated a 251-fold increased risk for narcolepsy in DQB1*0602 carriers and identified 4 protective DQB1 alleles (Tafti et al., 2014). A much smaller, but significant, predisposing effect of HLA-DPB1*05:01 in narcolepsy has recently been found in Asians (Ollila et al., 2015). The HLA genes encode molecules that present antigen fragments to the T-cell receptor in order to direct an immune response to a specific antigen. Other predisposing factors for narcolepsy are associations with a polymorphism in the T-cell receptor alpha and beta genes, whose products recognize antigens presented by HLA molecules, and Cathepsin $H$, which processes antigens for presentation (Faraco et al., 2013; Hallmayer et al., 2009; Han et al., 2013a). The purinergic receptor subtype P2Y11, which is expressed in cytotoxic lymphocytes and in the brain, has also been shown to be associated with narcolepsy (Kornum et al., 2011b). The tight linkage between narcolepsy and HLA subtypes and other genes involved in autoimmunity such as TNFSF4, IL1ORB-INFAR1, and P2YR11/DNMT1 (Faraco et al., 2013; Han et al., 2013a) strongly suggests an autoimmune basis for narcolepsy (Arango et al., 2015; Kornum et al., 2011a) (see Section 2.6).

\subsection{Comorbidities}

The range of symptoms in narcolepsy, including arousal state instability and cataplexy, along with other metabolic and autonomic features of the disease that are not yet fully understood, can make it difficult to understand where the entity of narcolepsy ends and where comorbidities begin. For example, night time sleep disturbance in narcolepsy, while a consequence of arousal state instability due to HCRT deficiency (see Section 2.4), can also be caused by comorbidities thought to reflect motor instability such as restless legs syndrome, REM sleep without atonia, or REM sleep behavior disorder (Frauscher et al., 2013; Plazzi et al., 2010).

Comorbidities were recognized by Legrand in one of the earliest descriptions of narcolepsy: "Encephalic congestion cardiac deficiency, gastric troubles or hepatic derangements, and such diseases as gout, diabetes, and rheumatism are some of its associations" (Legrand, 1888). Investigation into the comorbidities of narcolepsy began primarily with concerns for differential diagnosis or genetic associations, particularly with diabetes, depression, sleep apnea or parasomnias (Baker et al., 1986; Broughton et al., 1983; Honda et al., 1986; Mayer and Meier-Ewert, 1993). As the metabolic and autonomic abnormalities in narcolepsy began to be uncovered, concern was raised that patients with narcolepsy might be at a greater risk for serious, chronic conditions such as diabetes or cardiovascular disease. Recently, a wellcontrolled, prospective epidemiological study was undertaken to determine the odds ratios of medical and psychiatric disorders associated with narcolepsy in the United States (Ohayon, 2013). According to this study, digestive diseases, upper respiratory tract diseases, heart disease, hypercholesterolemia, and hypertension represented an increased risk in narcolepsy. Neither diabetes nor the metabolic syndrome was more prevalent in narcoleptic participants compared to age-, gender- and BMI-matched controls from the general population. Among 
the psychiatric conditions that present with a greater risk in narcolepsy, mood disorders were present in $19.2 \%$ of people with narcolepsy and primarily began after narcolepsy onset.

Panic disorder, simple phobia, agoraphobia, generalized anxiety disorder, and posttraumatic stress disorder also were found to occur at an increased frequency in narcolepsy. These phobias and anxiety disorders began after narcolepsy onset in most cases. Participants with narcolepsy were not at greater risk than the general population for alcohol dependency. Psychotic disorders were not assessed in this study because there was no case in the matched general population sample. However, schizophrenia and other psychotic disorders have been noted to begin in children after the onset of narcolepsy (Canellas et al., 2014). The consequences of these medical and psychiatric comorbidities in narcolepsy may, at least in part, underlie the 1.5-fold increase in mortality observed in narcolepsy (Jennum et al., 2013; Ohayon et al., 2014).

\section{Hypocretin/Orexin and disease mechanism}

\subsection{Narcoleptic dogs}

Narcolepsy has been described in other mammals including several breeds of dogs (dachshunds, poodles, Labrador retrievers and Doberman pinschers) (Mitler et al., 1976), horses (Dreifuss and Flynn, 1984; Lunn et al., 1993; Sweeney et al., 1983) and Brahman bulls (Strain et al., 1984). Although the mode of inheritance in small breed dogs is complex as it is in humans, large breed dogs such as Doberman pinschers and Labrador retrievers provide a simplified genetic system in which the mutation in the canine narcolepsy (canarc-1) gene is transmitted as an autosomal recessive trait with full penetrance (Foutz et al., 1979). Narcolepsy is also genetically transmitted in at least one breed of horse (Ludvikova et al., 2012). The existence of a genetic animal model of narcolepsy in dogs greatly facilitated research as it enabled the creation of a breeding colony to allow experimental pharmacological (Babcock et al., 1976; Delashaw et al., 1979; Mignot et al., 1988a,b; Mitler et al., 1976; Nishino and Mignot, 1997; Nishino et al., 1989), neurochemical (Faull et al., 1982, 1986; Mefford et al., 1983; Miller et al., 1990) and neurotransmitter receptor (Boehme et al., 1984; Bowersox et al., 1987, 1986; Kilduff et al., 1986; Mignot et al., 1988a,b) studies of narcolepsy to be conducted for the first time. The Food-elicited Cataplexy Test (FECT) was devised to enable quantitative assessment of cataplexy for pharmacological studies (Babcock et al., 1976; Mitler et al., 1976) and proved to be a useful tool for the assessment of drugs that ameliorated or exacerbated cataplexy (Nishino and Mignot, 1997). The general conclusion from these studies was that narcolepsy-cataplexy was likely a result of an imbalance between the monoaminergic and cholinergic systems resulting from monoaminergic hypoactivity and cholinergic hypersensitivity in the pons (Baker and Dement, 1985; Boehme et al., 1984; Mefford et al., 1983). Subsequent studies demonstrated that: (1) the activation of presynaptic adrenergic transmission likely underlies the anticaplectic activity of antidepressants (Mignot et al., 1993; Nishino et al., 1993), (2) the wake-promoting effects of the stimulants amphetamine and modafinil are mediated by presynaptic activation of dopamine (DA) neurotransmission (Mignot et al., 1994b) and (3) mesolimbic dopaminergic hypoactivity (Reid et al., 1996) and basal forebrain cholinergic hypersensitivity (Nishino et al., 1995) occur in narcolepsy. 
Although cataplexy, the pathognomonic symptom of narcolepsy, was unequivocally present in dogs, documentation of the occurrence of excessive sleepiness in these mutant animals was controversial and difficult to establish a species that can apparently sleep ad libitum in most domestic and laboratory situations (Kaitin et al., 1986a,b; Kushida et al., 1985; Lucas et al., 1979; Mitler and Dement, 1977). In contrast to the ease of evaluating cataplexy using the FECT, the labor-intensive nature of scoring of sleep/wake states based on EEG and EMG recordings limited the number of sleep pharmacology studies that were undertaken in narcoleptic dogs (Shelton et al., 1995).

In contrast to human narcolepsy, early studies established that the canarc-1 mutation was not associated with the dog equivalent of the HLA system (Dean et al., 1989; Motoyama et al., 1989). Identification of the genetic basis of autosomal recessive mutation in dogs in an era before genome sequencing existed was a challenging task, necessitating the creation of a canine genomic bacterial artificial chromosome (BAC) library (Li et al., 1999). Using this BAC library, canarc-1 was ultimately identified as a deletion mutation in the gene encoding Hcrt receptor 2 (Hcrtr2) (Lin et al., 1999) as described below.

\subsection{Dual discovery of hypocretins and orexins}

HCRT1 and HCRT2 are hypothalamic neuropeptides derived from a single precursor molecule (prepro-HCRT) by proteolytic processing (de Lecea et al., 1998; Sakurai et al., 1998). Although the HCRTs were formally described early in 1998 (de Lecea et al., 1998), subtraction cloning of the Hcrt gene from mouse and rat hypothalamus, localization of the cell bodies expressing the HCRT peptides, and description of their efferent projections was first reported at the 1997 Society for Neuroscience meeting (Peyron et al., 1997; Sutcliffe et al., 1997). Because the cell bodies expressing this gene were restricted to an area of the hypothalamus centered around the perifornical nucleus (PFH) and because of a weak homology to the gut peptide secretin, these molecules were called "hypocretins."

Just 6 weeks after the description of the HCRTs, these neuropeptides were independently reported by another group of investigators as ligands binding to cell lines expressing orphan G protein-coupled receptors (Sakurai et al., 1998). The chemical isolation procedure used allowed these investigators to determine that the longer of these two peptides was 33 amino acids in length and to define the N-terminal pyroglutamyl residue, the intrachain disulfide links, and the expected C-terminal amidation of both peptides. Since intracerebroventricular injections of these peptides increased food intake in rats, these investigators called the peptides orexin-A and orexin-B from the Greek root "orexis" meaning appetite. Importantly, this paper also reported functional information on the receptors for the two peptides: the orexin-1 receptor $\left(\mathrm{OX}_{1} \mathrm{R}\right)$ was shown to preferentially bind orexin-A over orexin-B, whereas the orexin-2 receptor $\left(\mathrm{OX}_{2} \mathrm{R}\right)$ bound both peptides with similar affinity (Sakurai et al., 1998). In the subsequent issue of Cell, the HCRTs and the orexins were confirmed to be the same peptides (Sakurai et al., 1998).

The nomenclature describing this neuropeptidergic system can be confusing. As indicated above, the term "hypocretin" appeared first in the literature referring to the two neuropeptides encoded by the preprohormone (de Lecea et al., 1998). However, the cognate receptors for these peptides were first called the "orexin receptors" (Sakurai et al., 1998).

Prog Neurobiol. Author manuscript; available in PMC 2018 May 01. 
The Human Genome Organization (HUGO) Gene Nomenclature Committee (Gray et al., 2015) and Genbank use the term "hypocretin (orexin)" to refer to both the peptides and the receptors and employ the abbreviations HCRT, HCRTR 1 and HCRTR 2 to refer to the genes encoding the preprohormone and the two receptors, respectively. In contrast, "The Concise Guide to PHARMACOLOGY 2013/2014" published by Committee on Receptor Nomenclature and Drug Classification of the International Union of Basic and Clinical Pharmacology (NCIUPHAR) refers to the receptors as "OX ${ }_{1}$ receptor" and "OX $\mathrm{X}_{2}$ receptor" (Alexander et al., 2013). Thus, both terminologies are used in the literature: the prepro-Hcrt gene is identical to preproorexin; HCRT1 is equivalent to orexin-A; and HCRT2 is identical to orexin-B. Here, we will use the terms "HCRT1" and "HCRT2" to denote the two peptides, "Hcrt" to refer to the HCRT/orexin-containing cells or to the Hcrt or orexin gene, and "HCRTR1" and "HCRTR2" to refer to the receptors for these peptides.

\subsection{Link to animal models of narcolepsy}

The Hcrt system was first linked to narcolepsy in 1999 when canarc-1 was identified as a deletion mutation in the Hcrtr2 gene (Lin et al., 1999). As described above, canarc-1 is transmitted as an autosomal recessive trait with full penetrance in Doberman pinschers and Labrador retrievers. Importantly, the mutation in these two breeds is in a different region of the Hcrtr2 gene, both of which result in a truncated, non-functional receptor protein.

Shortly thereafter, the prepro-orexin ligand knockout mouse was found to exhibit periods of behavioral arrest that strongly resembled cataplexy in dogs and humans (Chemelli et al., 1999). These mice also have a disrupted sleep architecture, particularly during the dark period, as evidenced by increased levels of both REM and NREM sleep, short latency REM periods, and decreased sleep bout durations. The identification of the canarc- 1 mutation as a deletion mutation in the Hcrtr2 gene through positional cloning and the creation of the orexin null mutant mouse were major advances in this field that not only drew a link between narcolepsy and the Hcrt system, but also suggested that this neuropeptidergic system, which had only been described 18 months earlier, might also be involved more generally in sleep/wake control.

Subsequently, HCRT1 levels were found to be normal in the CSF of Hcrtr2-mutated narcoleptic Doberman pinschers and Labrador retrievers but were reduced or undetectable in either CSF or the brain of poodles and mixed breed dogs that exhibited sporadic (i.e., nonfamilial) narcolepsy (Ripley et al., 2001). A mutation in Hcrtr2 in a family of dachshunds was identified in which the protein was appropriately localized to the cell membrane, but failed to bind ligand and, consequently, $\mathrm{Ca}^{2+}$ mobilization upon receptor stimulation was greatly compromised (Hungs et al., 2001). Collectively, these observations further solidified the link between the Hcrt system and narcolepsy and demonstrated that dysfunction in Hcrt neurotransmission - whether occurring presynaptically, as in the orexin ligand null mutant mouse, or postsynaptically, as in the Hcrtr2-mutated Doberman pinschers and Labrador retrievers - could result in the similar phenotype of narcolepsy with cataplexy. 


\subsection{CSF peptide levels and neurodegeneration in human narcoleptics}

Although these studies in narcoleptic dog and mouse models strongly implicated the Hcrt system, the first direct indication of an abnormality in Hcrt neurotransmission in narcoleptic humans was suggested by undetectable levels of HCRT1 in CSF from 7 of 9 narcoleptic patients (Nishino et al., 2000). At that point, it was uncertain whether the reduced CSF HCRT1 reflected a problem in release or in synthesis of the peptide. However, 9 months later, postmortem analyses demonstrated that HCRT mRNA was undetectable in two human narcoleptic brains, although melanin-concentrating hormone $(M C H)$ mRNA, a phenotypic marker of cells in the posterolateral hypothalamus that are distinct from Hcrt neurons, was readily detectable in both controls and narcoleptics (Peyron et al., 2000). Furthermore, an independently-conducted immunohistochemical study showed an 85-95\% reduction in the number of HCRT-containing cells in human narcoleptic brains with no evident change in the number of MCH cells (Thannickal et al., 2000). Increased staining for glial fibrillary acid protein in the PFH of the human narcoleptic brains suggested that neurodegeneration likely had occurred whereas the preservation of $\mathrm{MCH}$ cells suggested that the Hcrt neurons selectively degenerate, possibly through an autoimmune mechanism (see Section 2.5) (Thannickal et al., 2000). Along with the animal studies described above, these studies strongly suggested that degeneration of the Hcrt cells is the likely cause of human narcolepsy. Subsequent studies documented loss of substances that are colocalized with HCRT, the neuropeptides dynorphin (Crocker et al., 2005) and neuronal-activity-regulated pentraxin (Blouin et al., 2005), thereby confirming neuronal cell loss in the narcoleptic brain, at least for narcolepsy type 1, rather than an absence of HCRT expression.

The etiology of narcolepsy type 2 is less understood than the pathology underlying narcolepsy type 1. Most patients without cataplexy have HCRT1 levels above the criteria for narcolepsy type 1 diagnosis (Mignot et al., 2002), suggesting some degree of Hcrt neurotransmission may still occur in narcolepsy type 2 . An immunohistochemical study of a single postmortem human brain from a narcoleptic patient without cataplexy found only a $33 \%$ loss of Hcrt cells, suggesting that narcolepsy without cataplexy can result from a partial loss of the Hcrt neuron population (Thannickal et al., 2009). An MRI study found microstructural changes in the inferior frontal gyrus, postcentral gyrus, and amygdala in narcoleptic patients with cataplexy vs. normal controls, but no differences were detected between normal controls and narcoleptic patients without cataplexy (Nakamura et al., 2013). How these morphological changes might relate to Hcrt neurodegeneration is unclear. However, two independent groups have suggested that remodelling of wake-promoting systems occurs subsequent to loss of Hcrt neurons, as they reported an increase in the number of histaminergic (HA) cells in the tuberomammillary nuclei (TM) in post mortem tissue from narcoleptic patients with cataplexy (John et al., 2013; Valko et al., 2013), and the increase in HA cells correlates with the extent of Hcrt cell loss (Valko et al., 2013).

\subsection{Hypothesized autoimmunity}

While it is now well established that narcolepsy type 1 is caused by neurodegeneration of Hcrt cells and that a strong genetic component in immune function confers susceptibility to the disease, it is less clear how these two pieces fit together to fully understand the etiology of narcolepsy. The hypothesis that narcolepsy is an autoimmune disease that targets Hcrt 
neurons seems plausible but the mechanism has remained elusive for decades (Carlander et al., 1993; Mignot, 2014). Autoantibodies against HCRT peptides, HCRT receptors, or antigens co-localized on Hcrt neurons have evaded detection in numerous studies (Black et al., 2005; Overeem et al., 2006; Tanaka et al., 2006). The absence of identified autoantibodies in narcolepsy contrasts with other CNS autoimmune diseases (Graus et al., 2010), although some evidence for autoantibodies exists. Sera from a small group of patients with narcolepsy has been shown to bind tribbles homolog 2 (TRIB2) (Cvetkovic-Lopes et al., 2010) but, because this protein is expressed in many tissues both in CNS and in the periphery and not just in Hcrt neurons, TRIB2 autoantibodies are unlikely to be causative of Hcrt neurodegeneration (Kornum et al., 2011a) and instead may be secondary to the destruction of Hcrt cells (Liblau et al., 2015). When sera from narcoleptics and patients with other sleep disorders were screened on rat brain tissue, three distinct patterns of immunoreactivity were observed, one of which was identified to correspond to the Cterminal epitope of neuropeptide glutamic acid-isoleucine/alpha-melanocyte-stimulating hormone peptides (Bergman et al., 2014). A recent study, in which CSF samples from narcolepsy type 1 patients with early onset (within 1-12 months) were examined for changes in 51 cytokines and chemokines, did not find a difference in the levels of these immune markers compared to healthy controls (Kornum et al., 2015) and did not replicate a previously observed elevation of the cytokine interleukin 4 in this population (Dauvilliers et al., 2014a).

Infections can induce autoimmunity through a wide variety of mechanisms, including molecular mimicry, epitope spreading, bystander activation and superantigens, and a growing body of evidence suggests pathogens can trigger narcolepsy (Arango et al., 2015; Kornum et al., 2011a). Onset of narcolepsy is more frequent in spring and early summer than in winter, consistent with triggering by winter time upper airway infections (Han et al., 2011). Streptococcal throat infection has been associated with a 5.4-fold increased risk of narcolepsy (Koepsell et al., 2010), and anti-streptococcal antibodies have been detected in $65 \%$ of narcoleptic patients with recent onset compared to age-matched controls (Aran et al., 2009). Serum from children with Syndenham's Chorea or pediatric autoimmune neuropsychiatric disorders associated with streptococcal infections (PANDAS) has been shown to contain cross-reactive antineuronal antibodies that can alter dopaminergic signaling pathways (Chang et al., 2015), but whether a similar cross-reactivity can affect the Hcrt system remains to be determined. Homology between an epitope specific to the 2009 H1N1 strain and HCRT peptides was initially claimed (De la Herran-Arita et al., 2013) but subsequently retracted (De la Herran-Arita et al., 2014), so how an immune response to the virus may ultimately cause Hcrt cell death remains to be demonstrated.

Perhaps the most promising connection between narcolepsy and an infectious agent occurred following the $2009 \mathrm{H} 1 \mathrm{~N} 1$ influenza pandemic. In China, the incidence of narcolepsy increased three-fold in the 6 months after the peak of the outbreak, then decreased to the normal rate of onset by 2011 after the pandemic had been contained (Han et al., 2013b, 2011). As initially reported in Finland and Sweden (Bardage et al., 2011; Nohynek et al., 2012; Partinen et al., 2012) and later in other European countries (Dauvilliers et al., 2013a; O'Flanagan et al., 2014; Winstone et al., 2014), a 6-9-fold increase in new narcolepsy cases in children was observed a few months following vaccination against H1N1 with 
Pandemrix ${ }^{\circledR}$ — a formulation that contained the AS03 adjuvant. In contrast, no elevations in the rate of narcolepsy were reported in the U.S. where only non-adjuvanted vaccines were used (Duffy et al., 2014) or elsewhere in Europe where a closely related adjuvant, MF59, was used in the vaccine Focetria ${ }^{\circledR}$ (Ahmed et al., 2014; Calabro et al., 2013). Although these results suggest that the adjuvant AS03 could be problematic, no elevation in narcolepsy rates were observed in Canada where AS03 was also used as a component of the vaccine Arepanrix ${ }^{\circledR}$ (Montplaisir et al., 2014). However, although Pandemrix ${ }^{\circledR}$ and Arepanrix ${ }^{\circledR}$ were produced by the same manufacturer and administered with AS03, slightly different protocols for antigen isolation were utilized which resulted in more nucleoprotein and neuraminidase in Pandemrix ${ }^{\circledR}$ and a larger diversity of viral and chicken proteins in Arepanrix ${ }^{\circledR}$ (Jacob et al., 2015). This has led to the hypothesis that differential composition of the vaccines may be the key to understanding the increased incidence in narcolepsy in the affected populations (Ahmed et al., 2014; Jacob et al., 2015). A recent study (Ahmed et al., 2015) has shown that Pandemrix ${ }^{\circledR}$ contained $72.7 \%$ more influenza nucleoprotein than Focetria ${ }^{\circledR}$, and sera from HLA-DQB $1 * 0602$-positive patients with Pandemrix ${ }^{\circledR}$-associated narcolepsy contained antibodies that cross-reacted with the influenza nucleoprotein and HCRTR2. These antibodies were found in a significantly greater proportion of sera from patients with Pandemrix ${ }^{\circledR}$-associated narcolepsy compared to non-narcoleptic individuals with either a history of H1NI infection or Focetria ${ }^{\circledR}$ vaccination. Whether a similar mechanism of molecular mimicry against HCRT-related targets occurs in sporadic narcolepsy remains to be determined.

\subsection{Rodent models of narcolepsy}

Since the recognition that the prepro-orexin ligand knockout mouse has a behavioral phenotype that strongly resembles cataplexy (Chemelli et al., 1999), a number of rodent models have been produced to further understanding of the link between the Hcrt system and narcolepsy and as tools to probe the Hcrt system (Ch'ng and Lawrence, 2015; Darwinkel et al., 2014; De La Herran-Arita et al., 2011; Makela et al., 2010; Muraki et al., 2004; Tanaka et al., 2012; Tsunematsu et al., 2011, 2013) (Table 1). In mice, knockout of the HCRT precursor protein (Chemelli et al., 1999) or HCRT receptors (Kalogiannis et al., 2011; Kisanuki et al., 2001; Mieda et al., 2011; Willie et al., 2003), or genetic ablation of Hcrt neurons (Beuckmann et al., 2004; Black et al., 2013; Hara et al., 2001; Tabuchi et al., 2014) result in a narcoleptic phenotype including cataplexy, sleep/wake fragmentation and increased REM sleep propensity. The Hcrtr2 knockout mouse exhibits behavioral arrests resembling cataplexy but the phenotype is less severe than the Hcrt ligand knockout or the Hcrtr2-mutated narcoleptic dog (Willie et al., 2003). Although description of the Hcrtr1 knockout mouse has only appeared in abstract form (Kisanuki et al., 2001), cataplexy is thought to be mild (if it occurs at all) in these animals. Like their human counterparts (Besset et al., 1994; Dantz et al., 1994), narcoleptic mice exhibit normal homeostatic responses to sleep loss (Mochizuki et al., 2004). A rat model has been produced in which the Hcrt neurons are targeted with a HCRT2-saporin conjugate (Gerashchenko et al., 2003, 2001). Although these animals exhibit sleepiness and sleep attacks, neurons other than the Hcrt cells are likely also destroyed. 
In the orexin/ataxin-3 transgenic mouse model, the HCRT promoter drives expression of the polyglutamine neurodegenerative ataxin-3 protein, resulting in a postnatal loss of Hcrt neurons (Hara et al., 2001). Degeneration of the Hcrt neurons occurs postnatally with cataplexy occurring by 6 weeks of age. Orexin/ataxin-3 mice exhibit a phenotype strikingly similar to the Hcrtr2 mutant canine model (Lin et al., 1999) and the prepro-orexin knockout mouse (Chemelli et al., 1999) with deficits that include cataplexy (Black et al., 2013), premature entries into rapid eye movement (REM) sleep, and poorly consolidated sleep patterns. These animals also become obese relative to wild type mice, emulating the increased BMI characteristic of human narcoleptics (Dahmen et al., 2001; Kok et al., 2003; Schuld et al., 2002). A similar model has been produced in the rat, which exhibits episodes resembling cataplexy as well as fragmented vigilance states, decreased latency to REM sleep, and increased REM sleep time and decreased wakefulness during the dark (active) phase (Beuckmann et al., 2004). Despite profound cell loss, HCRT1 can be detected in CSF from these rats and prolonged wakefulness can further increase CSF HCRT1, indicating that the remaining Hcrt neurons can be activated (Zhang et al., 2007).

A conditional model of Hcrt neuron ablation has been introduced that in many ways is superior to the orexin/ataxin-3 transgenic mouse model (Tabuchi et al., 2014). In the orexin/ tTA; TetO diphtheria toxin model (the DTA mouse), degeneration of Hcrt neurons is controlled through the tetracycline transactivator (tTA) Tet-off (TetO) system. Dietary doxycycline (DOX) binds to the tetracycline transactivator (tTA) and prevents the synthesis of diphtheria toxin A fragment (DTA) through the TetO regulatory sequence. Because the tTA is attached to the HCRT promoter, removal of DOX from the diet (DOX(-) condition) initiates the synthesis of DTA for neurotoxic degeneration exclusively in Hcrt neurons. Thus, unlike orexin/ataxin-3 mice, DTA mice can be used in pre-post study designs to serve as their own Hcrt-intact controls. Hcrt neurodegeneration can be induced postpuberty to create a model with greater fidelity to most cases of human narcolepsy. The narcoleptic phenotype of these mice appears to parallel the symptomatic progression of human narcolepsy. As described in our original report (Tabuchi et al., 2014), DTA mice lost $\sim 86 \%$ of their Hcrt neurons and exhibited fragmented sleep/wake states by 1 week of DOX(-) that continued to worsen over subsequent weeks (Fig. 1). By 2 weeks of DOX(-), DTA mice lost $~ 95 \%$ of their Hcrt neurons; cataplexy first appeared and progressively increased in frequency until at least 11 weeks DOX(-). Compared to other mouse models of narcolepsy, cataplexy levels are high in these mice after 4 weeks of DOX(-) (>97\% Hcrt cell loss), as they exhibit approximately 20 to 60 cataplexy episodes on average during the dark period. The behavioral and electrophysiological aspects of cataplexy in DTA mice (Fig. 2) are similar to those observed in orexin/ataxin-3 and prepro-orexin knockout mice, including hypersynchronous theta activity in the EEG and abrupt behavioral immobilization (Bastianini et al., 2012; Vassalli et al., 2013). Partial Hcrt neuron ablation can also be induced by reinstatement of DOX after variable durations of DOX(-) to permit examination of the physiological consequences of reduced Hcrt cell numbers, and to perhaps model narcolepsy type 2. The DTA mouse will certainly expand the tool box for addressing a number of questions in narcolepsy, including developmental aspects and network reorganization in terminal fields as Hcrt input degenerates. 


\subsection{Hypocretin and the neural circuitry of arousal states}

Because narcolepsy is characterized by EDS as well as cataplexy and since the Hcrt cells are known to innervate the monoaminergic and cholinergic cell groups involved in the promotion of wakefulness (Date et al., 1999; Peyron et al., 1998), the Hcrt system was proposed soon after its discovery to be a wake-promoting system that provides excitatory input to the monoaminergic and cholinergic systems. In this model, the absence of excitatory input from the HCRT peptides in narcolepsy results in an imbalance between the monoaminergic and cholinergic systems and the consequent behavioral state instability (Kilduff and Peyron, 2000). This concept has been elaborated further in the "flip flop" switch model of arousal state control in which the Hcrt system is proposed to pivot the arousal systems from sleep to wake (Saper et al., 2001, 2010). A "flip flop" switch for REM sleep control has also been posited in which GABAergic populations that are active during REM sleep ("REM on") or that are silent during REM sleep and active during wakefulness ("REM off") mutually inhibit each other (Lu et al., 2006). In both of these models, the absence of stabilizing input from the HCRTs in narcolepsy causes rapid switching between wakefulness and sleep, especially REM sleep. Models of arousal state circuitry now incorporate excitatory input from Hcrt neurons to populations that are active during wakefulness (Fig. 3), including the noradrenergic locus coeruleus (LC; which receives the densest innervation), serotonergic dorsal raphe (DR), histaminergic TM nucleus, cholinergic basal forebrain (BF) and pontine reticular formation, and GABAergic ventrolateral periaqueductal gray (vlPAG) (Brown et al., 2012; Burgess and Scammell, 2012; Sakurai, 2014).

HCRT facilitates motor tone during wakefulness through direct excitation of motor neurons (Peever et al., 2003; Yamuy et al., 2004) and by suppression of the circuitry necessary for REM sleep atonia (Brown et al., 2012; Burgess and Scammell, 2012; Dauvilliers et al., 2014b; Luppi et al., 2011) (Fig. 3). During REM sleep, motor neurons are inhibited by glycine (Chase et al., 1989) and GABA (Brooks and Peever, 2008, 2012) from neurons in the medial medulla (MM) and by spinal interneurons (Krenzer et al., 2011). These medial medullary and spinal interneurons are stimulated by glutamatergic input from the sublaterodorsal nucleus (SLD, functionally equivalent to the subcoeruleus in cats) to induce atonia during REM sleep (Krenzer et al., 2011). Neurons in the SLD receive strong GABAergic inhibition during wakefulness that must be disinhibited for atonia to occur (Boissard et al., 2003, 2002; Pollock and Mistlberger, 2003). REM sleep atonia can also be induced via cholinergic excitation of the SLD (Brown et al., 2006; Heister et al., 2009). These GABAergic and cholinergic inputs to the SLD are controlled by monoaminergic (Aston-Jones and Bloom, 1981; Crochet et al., 2006; Hobson et al., 1975; McGinty and Harper, 1976) and hypocretinergic (Burlet et al., 2002; Mileykovskiy et al., 2005; Peyron et al., 1998) neurons that are active during wakefulness. In the absence of HCRT in narcolepsy, cataplexy results from disinhibition of the REM sleep atonia circuitry (Luppi et al., 2011) and disfacilitation of noradrenergic activation of motor neurons (Burgess and Scammell, 2012; Dauvilliers et al., 2014b) (Fig. 4).

Genetic knockout and transgenic mouse models of narcolepsy have enabled some of the neural circuitry underlying cataplexy mechanisms to be discerned. Building upon 
electrophysiological studies in narcoleptic dogs which showed that a population of cells in the central nucleus of the amygdala (CeA) was active during cataplexy (Gulyani et al., 2002), lesions of the CeA in prepro-orexin knockout mice markedly reduced cataplexy, especially in the context of strong emotional cues (Burgess et al., 2013). Neuronal activity, as indicated by Fos immunostaining in the dorsal portion of the medial prefrontal cortex (mPFC), positively correlated with the number of chocolate-elicited cataplexy bouts in prepro-orexin knockout mice (Oishi et al., 2013). Reversible suppression of mPFC activity with a conditional glutamate-gated chloride channel decreased this chocolate-elicited cataplexy (Oishi et al., 2013). Both the CeA and the mPFC (via the basolateral amygdala$\mathrm{CeA}$ circuit) send inhibitory GABAergic projections to brainstem regions that gate cataplexy, such as the vlPAG and the lateral pontine tegmentum (Burgess et al., 2013; Oishi et al., 2013). Focal restoration of HCRT by adeno-associated virus (AAV) gene transfer into the dorsolateral pons reduced cataplexy (Blanco-Centurion et al., 2013). Together, these studies provide evidence that activation of forebrain limbic circuitry by emotional stimulation underlies cataplexy triggering and support the hypothesis that Hcrt excitation may balance this limbic inhibition to maintain muscle tone.

Brainstem mechanisms underlie the direct inhibition and reduced excitation of motor neurons that defines cataplexy (Luppi et al., 2011; Peever, 2011). In narcoleptic dogs during cataplexy, neurons in the atonia circuitry of the MM become active (Siegel et al., 1991) and noradrenergic neurons of the LC become quiescent (Wu et al., 1999), but a causal role for noradrenergic neurons in cataplexy induction was uncertain. A recent study in prepro-orexin knockout mice has provided direct evidence that manipulation of adrenergic tone controls atonia during cataplexy (Burgess and Peever, 2013). In this study, antagonism of $a_{1}$ receptors on trigeminal motor neurons via microdialysis induced atonia of their masseter muscle targets during wakefulness. During cataplexy, the effects of this antagonism were absent, indicating lost adrenergic tone and cataplectic attacks were halted by application of an $\mathrm{a}_{1}$ agonist (Burgess and Peever, 2013). However, focal restoration of Hcrtr 1 in the LC of narcoleptic mice that lack both HCRT receptors failed to inhibit cataplexy, whereas cataplexy was blocked by targeted expression of Hcrtr 2 in the dorsal raphe (Hasegawa et al., 2014). These studies highlight the complexity of the circuitry that governs motor control during arousal states and exemplify new experimental approaches to discern these mechanisms.

\section{Therapeutics}

\subsection{Historical approaches}

Many health professionals in the late 1800 s viewed the narcolepsy syndrome as a form of epilepsy, despite Gelineau's and Westphal's arguments to the contrary (see "history" above). Others misinterpreted narcolepsy in Freudian terms as a hysterical defense mechanism, perhaps because Westphal's index case was a rapist who suffered from pathological sleepiness (Mignot, 2001). It is not surprising then that attempted treatments for the narcolepsy syndrome, as historically misunderstood at the turn of the 20th century, were ineffective and included the anti-epileptic potassium bromide, vasodilators picrotoxin and amyl nitrate vapors, agents aimed to improve motor abnormalities such apomorphine and 
strychnine, and, lastly, hydrotherapy, electricity and cauterization of the nape of the neck (Dement, 2007; Schenck et al., 2007). Even caffeine granules administered by Gelineau were found to be insufficient to counter narcoleptic sleepiness (Schenck et al., 2007). In the 1930s, mild success was found with the CNS stimulant ephedrine (Doyle and Daniels, 1932). Amphetamine was introduced to treat narcolepsy in 1935 and found to be more effective at controlling sleepiness (Prinzmetal and Bloomberg, 1935); it is still prescribed for this purpose (Hishikawa and Shimizu, 2007).

Pharmacological alleviation of cataplexy was first documented in 1960 with the unexpected discovery that the tricyclic antidepressant imipramine significantly decreased the occurrence of cataplexy (Akimoto et al., 1960). Neuropsychiatrists at the time hypothesized that the effectiveness of antidepressants to improve the mood and increase the activity levels of depressed and psychotic patients might also confer therapeutic potential of antidepressants to ameliorate the EDS of narcolepsy (Hishikawa and Shimizu, 2007). Although imipramine had no effect on EDS and irresistible sleep attacks, it did improve cataplexy (Akimoto et al., 1960) through its active metabolite desipramine (Hishikawa et al., 1966). These and other tricyclic antidepressants, such as protripty-line and clomipramine, were found to inhibit REM sleep and thereby control sleep paralysis and hypnogogic hallucinations in addition to cataplexy (Hishikawa and Shimizu, 2007). While tricyclic antidepressants non-selectively block serotonergic and noradrenergic reuptake as the therapeutic mechanism of action, they also antagonize histamine and muscarinic acetylcholine receptors, leading to frequently intolerable side effects such as sedation, dry mouth, sweating, constipation, blurred vision, sexual dysfunction, tachycardia, orthostatic hypotension and are contra-indicated in cardiovascular disease (Guilleminault and Cao, 2011; Mignot, 2012). Withdrawal from tricyclic antidepressants can also induce rebound cataplexy for several weeks after discontinuation of the medication (Ristanovic et al., 2009). The monoamine oxidase inhibitor selegiline, which increases synaptic DA in addition to serotonin and norepinephrine, has been noted to also strongly suppress REM sleep and improve EDS but has sympathomimetic side effects that limit its utility (Hublin et al., 1994).

\subsection{Current treatments}

Current treatments for narcolepsy are based on symptomatic management of sleepiness and cataplexy. At least half of all narcolepsy patients take medication to manage their condition (Ohayon, 2013) and may need to do so for the rest of their lives as there is no cure yet. Medication in combination with lifestyle adaptations helps return an estimated $80 \%$ of patients with narcolepsy back to near normal functioning (Mignot, 2012). Behavioral modifications such as scheduled bedtimes, wake-up times, and napping, either as long naps in the afternoon or several brief naps distributed throughout the day, can benefit daytime performance and sometimes reduce the doses of stimulants needed (Thorpy and Dauvilliers, 2015). Behavioral management of cataplexy has not been well developed, but patients themselves may choose to avoid or control known emotional triggers (CDER, 2013; Dauvilliers et al., 2014b). The US Food and Drug Administration (FDA) has approved five pharmacotherapeutics for the treatment of narcolepsy: sodium oxybate $\left(\mathrm{Xyrem}^{\circledR}\right)$, modafinil (Provigil ${ }^{\circledR}$ ), armodafinil (Nuvigil ${ }^{\circledR}$ ), methylphenidate, and amphetamine (CDER, 2013). 
3.2.1. Sodium oxybate-Sodium oxybate, the sodium salt of gamma-hydroxybutyrate (GHB), is currently the only approved drug to treat both cataplexy and EDS in narcolepsy (Bosch et al., 2012; Boscolo-Berto et al., 2012) and, as such, is favored as the first-line therapeutic. A randomized, double blind, placebo-controlled multi-center trial compared the effects of three doses of orally administered sodium oxybate with placebo for the treatment of narcolepsy in 136 patients (Study Group, 2002). Subjects received 3, 6, or $9 \mathrm{~g}$ doses of sodium oxybate or placebo taken in 2 doses, the first upon retiring and the second 2.5-4 $\mathrm{h}$ later, for 4 weeks. Compared to placebo, weekly cataplexy attacks were decreased by sodium oxybate at the $6 \mathrm{~g}$ dose $(p=0.0529)$ and significantly at the $9 \mathrm{~g}$ dose $(p=0.0008)$. The frequency of inadvertent naps or sleep attacks and nighttime awakenings showed similar dose-response trends, becoming significant at the $9 \mathrm{~g}$ dose (Study Group, 2002). In a followup study, 55 narcoleptic patients with cataplexy who had received continuous treatment with sodium oxybate for 7-44 months (mean 21 months) were enrolled in a double-blind treatment withdrawal paradigm (Study Group, 2003a). During the 2-week double-blind phase, the abrupt cessation of sodium oxybate therapy in the placebo patients resulted in a significant increase in the number of cataplexy attacks (median $=21 ; p<0.001$ ) compared to patients who remained on sodium oxybate (median $=0$ ). Cataplexy attacks returned gradually with placebo patients reporting a median of 4.2 and 11.7 cataplexy attacks during the first and second weeks, respectively (Study Group, 2004). Interestingly, there was no evidence of withdrawal following abrupt cessation of chronic sodium oxybate dosing in the therapeutic range (Study Group, 2003b), which is consistent with the observation that the minimum daily dose of sodium oxybate associated with withdrawal is $18 \mathrm{~g}$ (Miro et al., 2002). In a 12 month open label study, 118 patients exhibited a 90\% reduction in cataplexy without evidence of tolerance (Study Group, 2003a). Lastly, a double-blind, placebocontrolled study in 228 patients across 42 clinics found that nightly doses of $4.5,6$ and $9 \mathrm{~g}$ sodium oxybate for 8 weeks resulted in statistically significant median decreases in weekly cataplexy attacks of 57.0, 65.0 and 84.7\%, respectively (Study Group, 2005). Post FDA approval of sodium oxybate for cataplexy and EDS in a double-blind, placebo-controlled study showed that sodium oxybate improved nighttime sleep with a dose-related increase in slow wave sleep and total sleep time and a reduction in nocturnal awakening (Black et al., 2010).

The mechanism of action of sodium oxybate as a narcolepsy therapeutic has not yet been elucidated. Some researchers have proposed that the therapeutic efficacy may be mediated by the increase in slow wave activity during NREM sleep that has been seen after acute administration of sodium oxybate (Black et al., 2010; Boscolo-Berto et al., 2012; Van Cauter et al., 1997; Walsh et al., 2010), although others have questioned the physiological relevance of GHB-induced slow waves in the EEG (Meerlo et al., 2004; Vienne et al., 2010, 2012). Despite its acute sedating effects, the therapeutic efficacy of sodium oxybate gradually emerges over time and persists after the drug has been metabolized (Boscolo-Berto et al., 2012; Mamelak, 2009). This delayed effect suggests that the therapeutic mechanism may be indirect and possibly involves secondary interactions of $\mathrm{GABA}_{\mathrm{B}}$ receptors and DA transmission (Guilleminault and Cao, 2011; Huang and Guilleminault, 2009), perhaps through disinhibition of DA release via G-protein coupled inwardly rectifying potassium channels (Cruz et al., 2004). GHB is a low affinity $\mathrm{GABA}_{B}$ agonist that has been shown to 
preferentially inhibit GABAergic interneurons in the ventral tegmental area and consequently disinhibit dopaminergic cells—unlike high affinity $\mathrm{GABA}_{\mathrm{B}}$ agonists such as baclofen that directly inhibit both GABAergic interneurons and catecholamine neurons (Cruz et al., 2004). The effects of GHB are known to at least partially depend on the $\mathrm{GABA}_{\mathrm{B}}$ receptor (Brown and Guilleminault, 2011), as $\mathrm{GABA}_{\mathrm{B}}$ antagonists block GHBinduced inhibition of neurons (Jensen and Mody, 2001). The GHB prodrug gammabutyrolactone does not produce behavioral or EEG effects in mice lacking $\mathrm{GABA}_{\mathrm{B} 1}$ and $\mathrm{GABA}_{\mathrm{B} 2}$ subunits (Kaupmann et al., 2003; Vienne et al., 2010). Sodium oxybate may also exert therapeutic effects via the $a 4 \beta \delta$ subunit of the $\mathrm{GABA}_{\mathrm{A}}$ receptor, which has been identified as a high-affinity target for GHB and is likely the elusive, endogenous GHB receptor (Absalom et al., 2012).

While sodium oxybate is often well-tolerated and has been reported to have a positive impact on the lives of many patients with narcolepsy, it is not a medication without challenges. GHB is a controlled substance with abuse potential and possible neurotoxic side effects (Langford and Gross, 2011; van Amsterdam et al., 2012). Other side effects, even at recommended doses, include nausea, confusion, CNS and respiratory depression, neuropsychiatric depression and confusion, incontinence, sleepwalking, automatic behaviors, and involuntary movements $\left(\mathrm{Xyrem}^{\circledR}, 2005\right)$. Adverse events associated with GHB abuse consist of seizures, loss of consciousness and death $\left(\mathrm{Xyrem}^{\circledR}, 2005\right)$. Titration up to the final dose can help manage most side effects (Thorpy and Dauvilliers, 2015). Sodium oxybate has a short half-life and is usually administered in a split dose, once at bedtime and again 2.5-4 h later (Black et al., 2010), which can be difficult to manage. Sodium oxybate is contraindicated in patients with succinic semialdehyde dehydrogenase deficiency or those patients who are also taking sedative hypnotics or other CNS depressants.

3.2.2. Modafinil and armodafinil-For patients who cannot take sodium oxybate, racemic modafinil or the extended release formulation of enantiomerspecific armodafinil may be suitable alternatives. Modafinil was approved for the promotion of wakefulness in narcolepsy by the US FDA in 1998. A meta-analysis comparison of modafinil and sodium oxybate has indicated similar therapeutic efficacy of the two medications in controlling EDS; however, modafinil is ineffective at reducing cataplexy when compared to placebo (Golicki et al., 2010). In contrast to amphetamines, modafinil has limited dependency and abuse potential, induces wakefulness with less psychomotor agitation (Bastuji and Jouvet, 1988) and does not cause rebound hypersomnolence (Edgar and Seidel, 1997). However, some studies have shown that modafinil has rewarding properties as indicated by reinforcing, discriminative stimulus effects (Paterson et al., 2010) or conditioned place preference in mice (Shuman et al., 2012). Similarly, modafinil has been shown to increase motivation in mice as measured by progressive ratio breakpoint (Young and Geyer, 2010). Nevertheless, modafinil and armodafinil lack the symphathomimetic side effects of amphetamines and, as such, are the first-line choice of treatment to promote wakefulness (Guilleminault and Cao, 2011).

The mechanism of action of modafinil is still not fully understood but likely involves the dopamine transporter (DAT) to inhibit DA reuptake (Wisor, 2013). Modafinil has been 
shown to bind the DAT with very low affinity but high selectivity, with no binding at norepinephrine or serotonin transporters (Mignot et al., 1994b). Mice with genetic knockout of the DAT failed to increase wakefulness in response to modafinil (Wisor et al., 2001). Extracellular DA levels were increased in the caudate nuclei of narcoleptic dogs after modafinil administration, as would be expected by diminished activity of the DAT (Wisor et al., 2001). Whether modafinil, and particularly armodafinil, might also act postsynaptically as D1 or D2 agonists is still equivocal (Mignot et al., 1994b; Seeman et al., 2009; Young and Geyer, 2010; Zolkowska et al., 2009). Interestingly, modafinil has been shown to induce wakefulness more effectively in narcoleptic mice that lack either the HCRT ligand or Hcrt neurons vs. wild type littermates, which suggests that modafinil may act on components of wake-promoting systems that are facilitated as a compensatory response to disrupted Hcrt signaling (Willie et al., 2005), perhaps such as the mesolimbic D2 receptors that have been observed to increase in narcoleptic dogs (Bowersox et al., 1987). A proposed mechanism by which armodafinil may increase wakefulness through inhibition of sleep-active ventrolateral preoptic neurons has been ruled out because large, cell-specific lesions to this area do not inhibit wake promotion by armodafinil (Vetrivelan et al., 2014).

3.2.3. Methylphenidate and amphetamine-Methylphenidate and amphetamines are now second and third-line therapies, respectively, used to counter EDS in narcolepsy, usually to supplement modafinil or sodium oxybate (Thorpy and Dauvilliers, 2015). Like modafinil, methylphenidate and amphetamine promote wakefulness through presynaptic enhancement of DA release (Burgess and Scammell, 2012; Burgess et al., 2010; Nishino and Mignot, 2011). Amphetamine and methylphenidate both increase the release of DA and to a lesser extent, norepinephrine and serotonin (Mignot, 2012). Amphetamine also increases synaptic DA by reverse efflux through the DAT and, at higher doses, inhibits the vesicular monoamine transporter (VMAT), to increase intracellular DA concentration presynaptically (Leviel, 2011; Mignot, 2012). Methylphenidate primarily inhibits the DAT (Leonard et al., 2004). The D-isomer of these stimulants is more potent than the L-isomer in increasing wakefulness because it is more specific to DA neurotransmission (Nishino and Mignot, 2011). Although both enantiomers of amphetamine are equipotent at reducing REM sleep (Nishino and Mignot, 2011), L-amphetamine is more effective than D-amphetamine in decreasing cataplexy (Mignot, 2012). The anticataplectic effects of amphetamine may relate to its action at transporters for norepinephrine and/or serotonin, as selective DAT inhibition fails to reduce cataplexy (Wisor, 2013). Unlike modafinil, amphetamine has several other actions that lead to an unfavorable side effect profile, such as vasoconstriction and cardiac stimulation resulting from increased noradrenaline in the periphery. At high doses, amphetamines inhibit monamine oxidase to further increase synaptic DA, which can lead to cytotoxicity or psychosis (Leviel, 2011; Mignot, 2012). Rapid increases in DA concentration and high levels of DA release and reverse efflux probably contribute to amphetamine addiction (Volkow et al., 2009).

3.2.4. Antidepressants-Antidepressants have not been approved by the FDA for the treatment of cataplexy, as there are currently no clinical trials on the efficacy and safety of these compounds for the indication of narcolepsy. In practice, however, both older tricyclic antidepressants and newer, selective monoaminergic reuptake inhibitors have been used off 
label and are reported to be very effective at reducing cataplexy (Dauvilliers et al., 2014b; Mignot, 2012; Thorpy and Dauvilliers, 2015). Because antidepressants generally do not promote wakefulness, they are usually prescribed in combination with modafinil or other stimulants (Mignot, 2012). A series of pharmacological studies in narcoleptic dogs led to the conclusion that monoaminergic reuptake inhibitors alleviate cataplexy to the extent that they, or their metabolites, activate presynaptic noradrenergic neurotransmission (Nishino and Mignot, 1997) (see Fig. 3). For this reason, the highly selective serotonergic and noradrenergic reuptake inhibitor (SNRI) venlafaxine is the first-line choice of treatment for cataplexy among the antidepressants, and low doses (below the level required to treat depression) are sufficient for effective cataplexy treatment (Dauvilliers et al., 2014b; Mignot, 2012). The selective serotonergic reuptake inhibitor (SSRI) fluoxetine is also commonly used to alleviate cataplexy, but higher doses than the level needed to control depression are required, probably because its anticataplectic effect is likely mediated by its noradrenergicpromoting metabolite norfluoxetine (Langdon et al., 1986). SNRIs are advantageous over tricyclic antidepressants because, unlike the latter, they do not block muscarinic cholinergic, $\mathrm{H}_{1}$ histaminergic, nor a 1-adrenergic receptors, thereby resulting in fewer side effects (Dauvilliers et al., 2014b; Guilleminault and Cao, 2011). However, similar to tricyclic antidepressants, SNRIs are associated with an increase in the number and severity of cataplexy attacks after withdrawal, even with gradual tapering of the drugs (Ristanovic et al., 2009; Wang and Greenberg, 2013). Antidepressants have also been linked to the development of REM behavior disorder (Ju et al., 2011), although it is not clear if narcolepsy predisposes for this risk.

\subsection{Use of narcoleptic mouse models for therapeutic development}

The pharmacology of many of the narcolepsy therapeutics used today has been examined in narcoleptic dogs in studies aimed at elucidating the receptor subtypes, active metabolites and brain regions involved the therapeutic control of cataplexy (see Section 2.1). Prior to the discovery of HCRT, these neurochemical studies in narcoleptic dogs established that an imbalance between monoaminergic and cholinergic transmission contributes to cataplexy induction (Baker and Dement, 1985; Nishino, 2007; Nishino and Mignot, 1997). This imbalance was inferred from studies that showed a reduction of monoaminergic tone and/or cholinergic stimulation exacerbated cataplexy in narcoleptic dogs (Faull et al., 1986; Mefford et al., 1983; Nishino et al., 1991, 1990; Reid et al., 1994). Although it is unclear how the loss of Hcrt signaling leads to a cholinergic/aminergic imbalance, the absence of HCRT-induced excitation of monoaminergic cells in narcolepsy may underlie the observed compensatory increase in the sensitivity of these systems to wake-promoting compounds (see Section 3.2.2. and Fig. 4).

Pharmacological studies in mouse models of narcolepsy recapitulate the monoaminergic/ cholinergic imbalance first described in narcoleptic dogs. Compared to wild type controls, HCRT-deficient mice exhibit reduced DA turnover (Mori et al., 2010) and increased responsiveness to modafinil (Willie et al., 2005). Cortical release of DA, NE and 5-HT can be more potently evoked in Hcrtr2 knockout mice vs. wild types (Ortega et al., 2012). In prepro-orexin ligand knockout mice, activation of dopamine D1 receptors with SKF38393 or amphetamine decreased sleep attacks while blockade of this receptor with SCH23390 had 
the opposite effect (Burgess et al., 2010). This study also showed that cataplexy could be suppressed by amphetamine or blockade of dopamine D2-like receptors with eticlopride and exacerbated by the D2/D3 agonist quinpirole (Burgess et al., 2010), but these effects were not replicated by others (Black et al., 2013; Fujiki et al., 2009). Cholinergic hypersensitivity has been demonstrated in mice that lack both HCRT receptors, as the enzymes necessary for acetylcholine synthesis, vesicular transport and metabolite reup-take were upregulated in laterodorsal tegmental neurons (Kalogiannis et al., 2010). Enhancement of cholinergic tone with physostigmine and muscarinic antagonism with atropine increased and decreased cataplexy, respectively, in mice that lack both HCRT receptors (Kalogiannis et al., 2011). In orexin/ataxin-3 mice, exogenous HCRT increased wakefulness more effectively than in wild type controls (Mieda et al., 2004) whereas the HCRTR1 and HCRTR2 antagonist almorexant induced sleep less effectively (Black et al., 2013). Collectively, these findings suggest that, in murine narcolepsy, compensatory changes in monoaminergic and cholinergic pathways downstream from HCRT receptors are primed to facilitate wake promotion and play a role in cataplexy induction.

A challenge in the use of mouse models of narcolepsy to study cataplexy is the high interindividual variability in the expression of this phenotype. Although not well documented, the genetic background of the mouse model and environmental factors, such as physical restrictions from EEG recording tethers and handling stress, have been thought to reduce the frequency of cataplexy episodes (Hara et al., 2005; Scammell et al., 2009). To help foster uniformity between laboratories that had been attempting to capture the same presumed cataplexy behavior using different methodologies (variously termed "narcoleptic episodes", "abrupt arrests", "behavioral arrests", "direct transitions into REM", or "cataplexy-like events"), consensus criteria were established to define murine cataplexy (Scammell et al., 2009). An episode of murine cataplexy requires (1) abrupt nuchal atonia for $\geq 10 \mathrm{~s}$, (2) video-confirmed behavioral immobility, (3) theta-predominated EEG activity, and (4) $\geq 40 \mathrm{~s}$ of immediately prior wakefulness (Scammell et al., 2009). Individual prepro-orexin ligand knockout mice have been reported to exhibit a wide range in the frequency of presumed cataplexy during the first $4 \mathrm{~h}$ of the dark period, with episode counts ranging from 8 to 27 (Chemelli et al., 1999), 2 to 87 (Willie et al., 2003), and 1 to 31 (Morawska et al., 2011). Other studies have reported presumed cataplexy in the prepro-orexin ligand knockout mice during the first $4 \mathrm{~h}$ of the dark period to occur with a mean ( \pm S.E.) frequency ranging from $25.1 \pm 8.7$ (Kisanuki et al., 2001), $18 \pm 9$ (Espana et al., 2007), $8.5 \pm 2.5$ (Liu et al., 2008), and $2 \pm 1$ (Burgess et al., 2010). In orexin/ataxin-3 transgenic mice, presumed cataplexy during the entire $12 \mathrm{~h}$ dark period has occurred with a mean ( \pm S.E.) frequency ranging from $4.8 \pm 3.2$ (Fujiki et al., 2009), $16.4 \pm 2.3$ (Liu et al., 2011), 9.3 \pm 2.2 (Black et al., 2013), $12.4 \pm 3.9$ (Kantor et al., 2013), $7 \pm 2$ (Tabuchi et al., 2014) and $6.5 \pm 1$ (Hasegawa et al., 2014). In a survey of 39 hemizygous orexin/ataxin-3 mice instrumented for telemetric EEG and EMG recording, $34 \%$ of the mice exhibited $<3$ episodes of consensus-defined cataplexy during the dark period (Black, unpublished observation). This wide variability in basal cataplexy expression can challenge interpretation of studies that use between-groups study designs (Blanco-Centurion et al., 2013; Hasegawa et al., 2014; Kantor et al., 2013; Liu et al., 2011). 
Interventions that significantly increase cataplexy frequency have included stimuli intended to evoke strong emotions, such as novel environments (Mieda et al., 2004), controlled access to running wheels (Espana et al., 2007), highly palatable food (Clark et al., 2009) including chocolate (Oishi et al., 2013; Tabuchi et al., 2014), the combination of chocolate and running wheels (Burgess et al., 2013), and attractive or aversive odors (Morawska et al., 2011). While chocolate has been shown to be highly effective at increasing cataplexy from 1.6-fold (Tabuchi et al., 2014) to 8.1-fold (Oishi et al., 2013), it could potentially confound studies by introducing dietary changes or secondary effects of prolonged wakefulness. For example, the three-fold increase in cataplexy observed after chocolate with a running wheel increased wakefulness to $90 \%$ of the $12 \mathrm{~h}$ dark period (Burgess et al., 2013). A manipulation that stays within the bounds of the Hcrt signaling system could represent a more pure means of amplifying cataplexy. For example, cataplexy has been shown to be provoked in orexin/ ataxin- 3 mice in a dose $\times$ time related manner with the dual HCRT receptor antagonist almorexant (Black et al., 2013), which has led to its use in a murine narcolepsy/cataplexy assay for pharmacological studies. This assay combines a pretreatment of almorexant at the start of the dark period with a dose 30 min later of either a test compound or desipramine ( 5 $\mathrm{mg} / \mathrm{kg}$ ) as a positive control for cataplexy reduction (see Section 3.1) in the presence of a running wheel. The combination of almorexant $(30 \mathrm{mg} / \mathrm{kg})$ and desipramine $(5 \mathrm{mg} / \mathrm{kg})$ does not change the amount of time spent awake, but enables both an increase and a decrease in cataplexy to be observed in orexin/ataxin-3 mice (Fig. 5). A separate control condition in the dual dosing paradigm with a wake-promoting therapeutic such as modafinil (Fujiki et al., 2009) (see Section 3.2.2) can be added to the assay to enable full assessment of both anticataplectic and wake-promoting efficacy of test compounds.

\subsection{Future therapies}

3.4.1. Pharmacotherapeutics on the horizon-Histaminergic neurons in the tuberomammillary nucleus of the posterior hypothalamus are one of the targets of Hcrt innervation (Peyron et al., 1998) that mediate HCRT-induced wakefulness (Huang et al., 2001; Mochizuki et al., 2011). In narcolepsy, CSF histamine levels are reduced compared to healthy controls, especially in patients with HCRT1 deficiency (Nishino et al., 2009). The activity of histaminergic neurons is preserved during cataplexy which is thought to underlie the maintenance of consciousness (John et al., 2004). For these reasons, it has been hypothesized that increasing histaminergic tone by antagonism of the histamine $\mathrm{H} 3$ autoreceptor could exert therapeutic effects on EDS in narcolepsy. The histamine H3 inverse agonist pitolisant has recently been tested for efficacy as a wakefulness promoter in 95 narcoleptic patients in a double-blind, randomized, parallel-group controlled clinical trial (Dauvilliers et al., 2013b). Pitolisant was found to increase wakefulness more than placebo and to a level indistinguishable from modafinil as measured by the Epworth Sleepiness Scale (Dauvilliers et al., 2013b). While pitolisant may be ultimately become a useful wakepromoting therapeutic in practice, it is not expected to show anticataplectic effects as histaminergic cells remain active during cataplexy (John et al., 2004).

ADX-N05 is a phenylalanine derivative with dopaminergic and noradrenergic activity that has been assessed for treatment of daytime EDS in narcolepsy (Bogan et al., 2013). In a 10center double-blind, placebo-controlled, randomized, cross-over study, ADX-N05 (150-300 
$\mathrm{mg}$ /day) increased mean sleep latency by $11.8 \mathrm{~min}$ on the Maintenance of Wakefulness Test (MWT) compared to placebo, as well as on the Epworth Sleepiness Scale (ESS) and the Clinical Global Impressions-Change (CGI-C) after one week of treatment. A subsequent Phase 2 study confirmed the results on the primary (sleep onset latency on the MWT) and secondary (ESS and CGI-C) efficacy endpoints in patients with narcolepsy (Black et al., 2014a). To this point, there is no evidence that ADX-N05 (now known as JZP-110) is effective in cataplexy.

$\mathrm{GABA}_{\mathrm{B}}$ agonism with R-baclofen, an enantiomer-specific form of racemic baclofen that has been used for decades in the treatment of muscle spasticity (Hudgson and Weightman, 1971), has recently been evaluated as a narcolepsy therapeutic in a preclinical study using two mouse models of Hcrt neuron ablation (Black et al., 2014b). The original goal of the research was to use the $\mathrm{GABA}_{\mathrm{B}}$ agonist baclofen in its most bioactive isoform as a tool compound to probe the therapeutic mechanism of action of sodium oxybate, which is known to be a partial agonist at $\mathrm{GABA}_{\mathrm{B}}$ receptors (Xie and Smart, 1992). It was hypothesized that if sodium oxybate acts on the $\mathrm{GABA}_{\mathrm{B}}$ receptor to normalize arousal states, then R-baclofen would mimic the effects of sodium oxybate on the symptoms of narcolepsy. At the doses tested (in a paradigm to model the chronic, twice-nightly administration of sodium oxybate in humans), R-baclofen was more effective than sodium oxybate at increasing the duration, intensity and consolidation of NREM sleep. As a consequence, the narcoleptic mice spent more time in consolidated bouts of wakefulness during the subsequent active phase. Rbaclofen was also more effective than sodium oxybate at reducing cataplexy. Whether the high-affinity $\mathrm{GABA}_{\mathrm{B}}$ receptor agonist R-baclofen exerts greater anticataplectic efficacy via $\mathrm{GABA}_{\mathrm{B}}$ receptors on glutamatergic SLD neurons (Fig. 4) than the low affinity agonist sodium oxybate needs to be determined. The evaluation of R-baclofen and racemic baclofen in a mouse model of Fragile $\times$ Syndrome has led to clinical trials of arbaclofen (STX209) (Berry-Kravis et al., 2012; Pacey et al., 2011) and, more broadly, to preclinical efficacy tests of baclofen isoforms in mouse models of autism (Silverman et al., 2015). These paths of research encourage clinical trials of arbaclofen for narcolepsy.

3.4.2. Hypocretin replacement therapy-Replacement of the HCRT that is lost from Hcrt neurodegeneration, like replacement of lost DA in Parkinson's disease, is an obvious therapeutic approach, but a number of obstacles must be overcome before being realized. However, since cataplexy and sleep fragmentation are exacerbated in narcoleptic orexin/ ataxin-3 mice treated with the dual HCRTR antagonist almorexant, only small amounts of HCRT may be necessary for therapeutic benefit (Black et al., 2013). The proof of principle that HCRT replacement therapy could be effective stems from a study in which the narcoleptic mouse phenotype was independently rescued by pharmacological and genetic means. In the first approach, intracerebroventricular administration of HCRT1 into orexin/ ataxin-3 mice (in which the vast majority of Hcrt neurons are ablated) rescued the narcoleptic phenotype (Mieda et al., 2004). Neither the HCRT2 peptide nor any HCRT fragments were tested for efficacy so whether other molecules related to HCRT1 can also rescue the phenotype is currently unknown. In the second approach, transgenic mice that express prepro-orexin under control of CAG promoter were bred with Hcrt neuron-ablated orexin/ataxin-3 mice to generate CAG/orexin; orexin/ataxin-3 mice. In these double 
transgenic mice, prepro-orexin is ectopically expressed throughout the brain but the Hcrt neurons are ablated. Narcolepsy symptoms such as sleep onset REM sleep, fragmentation of wakefulness in the dark period and cataplexy were completely inhibited in CAG/orexin; orexin/ataxin-3 mice, indicating that ectopic HCRT production could prevent narcolepsy.

Given the efficacy of HCRT treatment for cataplexy suppression in the proof-of-principle study described above, a small molecule, brain penetrable HCRT receptor agonist would be ideal for symptomatic treatment of narcolepsy. Although the dual orexin receptor antagonist suvorexant has recently been approved by the FDA for the treatment of insomnia, development of agonists for $\mathrm{G}$ protein-coupled receptors is much more difficult than developing antagonists. Among other factors, the HCRT peptides are 33 and 28 amino acids in length and each peptide assumes a particular tertiary conformation in vivo. Screening for a small molecule that fits the binding pocket of HCRTR1 and/or HCRTR2 and contacts the necessary residues for receptor activation is a challenging task. However, the recentlydescribed crystal structure of the human HCRTR2 (Yin et al., 2015) may accelerate development of orexin receptor agonists. Indeed, a non-peptide agonist that is selective for HCRTR2 with submicromolar potency has recently been introduced (Nagahara et al., 2015); however, the potential clinical utility of the compound remains to be determined.

A major hindrance in the development of HCRT replacement therapy, whether the replacement molecule is the exogenous peptide, a prodrug precursor, or a small molecule agonist, is penetration of the blood-brain barrier. Delivery of HCRT1 through an alternative entry to the CNS along olfactory nerves has been attempted with intranasal administration in animals (Deadwyler et al., 2007; Dhuria et al., 2009) and narcoleptic patients (Baier et al., 2011; Weinhold et al., 2014) with limited success. A new technology that may aid delivery of HCRT peptides through the blood-brain barrier is receptor-mediated transcytosis using "Brain Shuttle" constructs (Niewoehner et al., 2014). The current Brain Shuttle technology consists of an anti-transferrin antibody that has been modified to monovalently bind the transferrin receptor (thereby resisting lysosomal degradation) which can also be fused to either another antibody (Niewoehner et al., 2014) or, hopefully in the future, to macromolecules such as HCRT1 as the therapeutic cargo.

3.4.3. Genetic and stem cell therapies-Another potential approach is viral vectorbased delivery of the prepro-HCRT gene. Expression of HCRT using recombinant adenoassociated virus (rAAV) in neurons of the zona incerta or lateral hypothalamus effectively prevented cataplexy in narcoleptic orexin/ataxin-3 mice (Liu et al., 2011); transfer into the striatum was ineffective. Orexin gene transfer into the dorsolateral pons of orexin $\mathrm{KO}$ mice also significantly decreased cataplexy and modestly improved wake maintenance compared to orexin KO mice that did not receive rAAV (Blanco-Centurion et al., 2013). Orexin gene transfer into the mediobasal hypothalamus only improved the timing and consolidation of sleep and wakefulness and did not change cataplexy in orexin/ataxin-3 mice (Kantor et al., 2013). Together, these results strongly suggest that viral-based $H C R T$ replacement may be another avenue for treatment of narcolepsy.

Novel approaches using pluripotent stem cells for treatment of narcolepsy are also under development. The use of induced pluripotent stem cells as in vitro models specific to

Prog Neurobiol. Author manuscript; available in PMC 2018 May 01. 
individuals with narcolepsy has recently been proposed as a means to identify potential autoantigens as well as cell degenerative and survival responses (Liblau et al., 2015). Several groups have recently succeeded to generate hypothalamic neuropeptidergic neurons, including Hcrt neurons from human pluripotent stem cells (Merkle et al., 2015; Wang et al., 2015). Although much work is yet to be done, transplantation of HCRT-producing neurons generated from pluripotent stem cell from narcolepsy patients might become a useful treatment for narcolepsy in the future.

3.4.4. Immuno or neuroprotective therapies-Assuming that narcolepsy is indeed due to an autoimmune attack on Hcrt neurons, the most fundamental treatment would be prevention of its development using immunotherapies or neuro-protective strategies. This approach is challenging due to the difficulty in finding suitable numbers of cases of narcolepsy close to disease onset for well-controlled studies. In a case of childhood narcolepsy, the immunosuppressant prednisone failed to improve EDS and to prevent the development of cataplexy when administered 3 months after abrupt onset (Mignot and Nishino, 2007). Attempts to remove hypothesized autoantibodies with intravenous immunoglobin (IVIg) have produced mixed results. Early attempts at IVIg therapy resulted in subjective improvement in EDS and cataplexy despite persistently low HCRT1 levels, but effects were not seen in cases in which narcolepsy onset was a year or more prior to IVIg (Dauvilliers et al., 2004). However, IVIg administered very close to disease onset (15 d) normalized HCRT1 levels and resulted in clinical improvement in cataplexy (Dauvilliers et al., 2009). More recent attempts using IVIg found that HCRT1 levels remained abnormal and any symptom improvements tended to be temporary (Knudsen et al., 2012, 2010; Valko et al., 2008).

\section{Perspective}

\subsection{Voice of the patient}

In 2013, the US. FDA issued a patient-focused drug development initiative in which public meetings were held to gather information from the patients' perspective in 20 specific disease areas. One of these meetings focused on narcolepsy in order to directly hear from patients, their caregivers and advocates about the impact of the disease on their lives and their experiences with currently available therapies. Several key themes emerged from the dialog with over 120 participants and highlighted the chronic, debilitating toll that narcolepsy takes on patients' lives and the challenges they face in managing their condition (CDER, 2013). First, patients emphasized that EDS is the most problematic symptom that affects their lives, mostly because of the difficulty they face in fighting against it, or the consequences they face from chronic sleep deprivation such as cognitive impairments, the feeling of "brain fog", and automatic behaviors. Second, the unpredictable loss of control that accompanies cataplexy, hallucinations and sleep paralysis can be terrifying. Other aspects of the disease, such as weight gain, insomnia, mood changes and depression were specifically noted as detrimental to patients' lives. Third, patients reported that their symptoms can change over time. For example, a seasonal or monthly change occurs in their ability to sleep, or new symptoms emerge, such as cataplexy. Some symptoms, even when treated, worsen with time. Fourth, many patients reported that challenges often arise with 
medication use, including variable effectiveness, side effects, the development of tolerance, and access to currently-available treatments. These challenges necessitate a continued need to switch therapeutics, which is itself problematic. Last but not least, patients emphasized the significant impact that narcolepsy exerts on their social, emotional, and financial wellbeing and the frustration they experience as their disorder is misunderstood by colleagues, health care providers, and other people in their lives. This report from the patients' perspective on narcolepsy underscores the critical need for innovative new therapies to improve patients' lives. It also highlights some areas of unmet needs faced by patients, such as cognitive impairment, automatic behavior and anxiety, that have not yet been specifically addressed in drug development for narcolepsy.

\subsection{Challenges in the development of narcolepsy therapeutics}

Before discussing the challenges in the development of narcolepsy therapeutics, it is appropriate to assess the advantages in targeting this disorder. First, despite the earlier confusion with epilepsy, narcolepsy type 1 is readily identified as a distinct diagnostic entity. Although other sleep disorders such as sleep apnea can result in EDS and even disrupted nighttime sleep, cataplexy is the pathognomonic symptom that is diagnostic of this disorder. Second, narcolepsy has clearly defined criteria used in both research and clinical (Eichler, 2014) settings. As described above (see Section 1.2.2), one of the first applications of the MSLT was to aid in the diagnosis of narcolepsy (Richardson et al., 1978) and the MSLT has proven to be useful as an objective measure of EDS for the subsequent $\sim 40$ years. Third, the loss of Hcrt neurons in the hypothalamus is now widely accepted as the cause of narcolepsy type 1. Although the reason for this cell loss that would complete our understanding of the etiology of this disorder remains obscure, the consequent interruption of Hcrt neurotransmission resulted in another asset for study of this disorder: a decline of CSF HCRT1 levels that has thereby enabled a diagnostic test. Fifth, recognition of Hcrt cell loss and interruption of Hcrt neurotransmission as an essential component of human narcolepsy type 1 has allowed creation of numerous animal models that recapitulate various symptoms of narcolepsy. These animal models will be extremely valuable for testing of potential therapeutics, as exemplified by a recent study (Black et al., 2014b). Particularly critical for future therapeutic development have been the proof of principle studies that have utilized some of these animal models to demonstrate mitigation of cataplexy and normalization of REM sleep levels after HCRT replacement by either pharmacological or genetic means (Blanco-Centurion et al., 2013; Liu et al., 2011; Mieda et al., 2004). Sixth, recognition of Hcrt cell loss as the source of interruption of Hcrt neurotransmission suggests that, in contrast to Hcrtr2-mutated narcoleptic Doberman pinschers and Labrador retrievers, HCRT receptors in human narcoleptics are intact and functional and thus represent viable pharmacological targets for HCRT replacement therapy whether by small molecule agonists or other innovative therapeutic means. Lastly, the search for new therapeutics will be greatly aided by the rich database of information that has resulted from extensive pharmacological testing in narcoleptic Doberman pinschers (Crocker et al., 2005; Nishino and Mignot, 1997), as these studies have suggested the downstream targets of Hcrt innervation that become unbalanced with Hcrt cell loss and should be normalized by effective therapeutics. 
Despite the advantages stated above, a number of obstacles remain problematic for future development of narcolepsy therapeutics. Perhaps the paramount obstacle is the relatively low prevalence of this disorder which may limit the number of companies that are willing to invest in new therapeutic development for a disorder with a small market. With a prevalence of $0.05 \%$, there are approximately 150,000 individuals with narcolepsy in the US. This is obviously a small fraction of the population of patients that are suffering from depression, autism or Alzheimer's disease, for example. On the other hand, the US. Orphan Drug Act of 1983 was specifically designed to facilitate the development and commercialization of drugs to treat rare diseases such as narcolepsy. The FDA's Office of Orphan Products Development administers the Orphan Drug Designation program that provides orphan status to drugs and biologics for the treatment diseases and disorders that affect fewer than 200,000 people in the US. Government intervention on behalf of orphan drug development can be in the form of tax incentives, enhanced patent protection and marketing rights, subsidization of clinical research and even the creation of a government-run enterprise to engage in research and development. Since 1984, seven applications for orphan drug status for the treatment of narcolepsy have been successful (Table 2). As the era of the multi-billion dollar blockbuster drug recedes and precision medicine segments diseases and disorders into smaller markets, rare disorders and diseases, particularly life-long diseases with early age of onset such as narcolepsy, may become more attractive to large pharmaceutical companies specifically because of the possibility of orphan drug designation and the resultant market exclusivity.

Another major challenge in the development of narcolepsy therapeutics is the incomplete understanding of the etiology of this disorder. Although loss of Hcrt cells is widely accepted the final endpoint of narcolepsy type 1, it is unclear why Hcrt neurons are lost in the first place. While some evidence suggests that narcolepsy type 2 may result from less severe loss of Hcrt neurons than in narcolepsy type 1 (Thannickal et al., 2009), whether these two types of narcolepsy differ in patterns of neurodegeneration, mechanisms of cell loss, compensatory preservation of remaining cells or Hcrt function (e.g., axonal sprouting, increased HCRT release, decreased degredation, etc.) is unknown. Clearly, a genetic predisposition involving the HLA system has been established as an important component across multiple ethnic populations and in family studies, but only about $25 \%$ of monozygotic twins are concordant for narcolepsy (Mignot, 1997), implicating unspecified environmental factors that may vary among patients. Although an autoimmune mechanism was suggested by the original association with HLA-DR2 over 30 years ago (Juji et al., 1984), as indicated in Section 2.5, the search for autoantibodies in sporadic narcolepsy has been fruitless to date, which stands in stark contrast to well-established autoimmune neurological disorders such as myasthenia gravis (Graus et al., 2010). Nonetheless, it is appropriate here to keep in mind the old adage that "absence of evidence is not evidence of absence." The existence of streptococcal infections in a large proportion of recent narcolepsy onset cases may be an important clue both in the search for an environmental trigger and in the mechanism of the autoimmune response (Aran et al., 2009).

Surmounting the blood-brain barrier is a formidable challenge to any drug development effort directed toward a CNS target. In the case of narcolepsy, as indicated above, the most straightforward therapeutic strategy for symptomatic treatment would be HCRT replacement therapy. However, because the HCRTs are neuropep-tides, peripheral administration renders 
them vulnerable to enzymatic hydrolysis, although the disulfide bridges and two alphahelices in HCRT1 (Kim et al., 2004) confers greater stability than that of HCRT2 (Lee et al., 1999). For small molecules, the size and charge limitations encapsulated in Lipinski's rule of 5 applies (Lipinski et al., 2001). Hypocretin replacement therapy enabled by gene transfer may be one means of bypassing the blood-brain barrier, however, controlling the diurnal timing of ectopic $H C R T$ expression and its restriction to wakefulness is an important problem that has not yet been solved (Willie et al., 2011). Until a solution is found, the nighttime use of HCRTR1 and HCRTR2 antagonists, such as suvorexant (Michelson et al., 2014), could conceivably be employed, but the benefit of increased sleep propensity must be weighed against the possibility of cataplexy exacerbation in patients with narcolepsy (Black et al., 2013). Construction of a "Brain Shuttle" for receptor-mediated transcytosis across the blood-brain barrier (see Section 3.4.2) is a promising approach, but the technology is still in its infancy for peptide delivery. Determination of the minimal peptide length of the HCRTs that can both bind to the shuttle antibody and engage HCRTR2 to effect a cellular response is a difficult challenge.

With respect to small molecule development, HCRT replacement therapy implies synthesis of an agonist at the HCRT receptors. In contrast to antagonists, identification of receptor agonists is much more difficult, likely due to the constraints on identifying molecules that can both fit the binding pocket of a particular receptor and contact the appropriate amino acid residues for receptor activation. The recently-described crystal structure of the human HCRTR2 (Yin et al., 2015) may facilitate development of receptor agonists by enabling virtual screening of compounds. Another approach would be the development of a positive allosteric modulator at the HCRT receptors, but the efficacy of this approach will be limited by the availability of enough endogenous ligand to activate the receptor. On the other hand, postmortem human studies suggest that $5-15 \%$ of Hcrt neurons may remain even in patients who have experienced narcolepsy symptoms for over 50 years (Thannickal et al., 2000). Furthermore, only a small degree of HCRT receptor activation may be necessary for therapeutic benefit since cataplexy and sleep fragmentation are exacerbated in narcoleptic orexin/ataxin-3 mice treated with almorexant (Black et al., 2013).

In conclusion, narcolepsy represents a model neurodegenerative disease for the development of therapeutics. The loss of a small, discrete and homogeneous population of neurons translates to a relatively simple system in which to develop gene- and pharmacology-based therapies. Although the symptomatic consequences of Hcrt cell loss are wide and varied, rodent animal models recapitulate the cardinal features of arousal state boundary dysregulation and cataplexy with clearly defined end points. Restoration of Hcrt neurotransmission, whether by small molecule agonists or by exogenous peptides, may be the most parsimonious means of treating the many disparate features of narcolepsy. Whether the compensatory neurochemical and molecular changes that accompany Hcrt cell loss can be fully surmounted, or even reversed, remains to be determined. Until the cause of Hcrt neurodegeneration can be understood and prevented, development of therapeutics to provide symptomatic relief by improving Hcrt neurotransmission remains a worthy goal. 


\section{Acknowledgments}

This work was supported by NIH R01 HL059658, R01 NS077408, R21 NS087550, R01 NS082876, R21 NS083639 and R21 NS085757. We thank Drs. Michael Schwartz, Theresa Steininger and Jed Black for helpful comments on the manuscript. The content is solely the responsibility of the authors and does not necessarily represent the official views of the National Institutes of Health.

\section{Abbreviations}

5-hydroxytrytamine (serotonin)

$\mathbf{a}_{1} \quad$ noradrenergic alpha 1 receptor

$\mathbf{a}_{2} \quad$ noradrenergic alpha 2 receptor

ACh acetylcholine

Atax orexin/ataxin-3 transgenic

BAC bacterial artificial chromosome

BAT brown adipose tissue

BF basal forebrain

BLA basolateral amygdala

BMI body mass index

CeA central nucleus of the amygdala

CGI-C Clinical Global Impressions-Change

CSF cerebrospinal fluid

Ctx cerebral cortex

D1 dopamine 1 receptor

D2 dopamine 2 receptor

D3 dopamine 3 receptor

DA dopamine

DAT dopamine transporter

DOX doxycycline

DR dorsal raphe nucleus

DTA orexin/tTA

TetO DTA transgenic

EDS excessive daytime sleepiness 


\begin{tabular}{|c|c|}
\hline EEG & electroencephalograph \\
\hline EMG & electromyograph \\
\hline ESS & Epworth Sleepiness Scale \\
\hline FDA & Food and Drug Administration \\
\hline FECT & Food-elicited Cataplexy Test \\
\hline GABA & gamma-aminobutyric acid \\
\hline $\mathbf{G A B A}_{\mathbf{A}}$ & gamma-aminobutyric acid A receptor \\
\hline $\mathbf{G A B A}_{\mathbf{B}}$ & gamma-aminobutyric acid B receptor \\
\hline Glu & glutamate \\
\hline Gly & glycine \\
\hline H3 & histamine receptor 3 \\
\hline HA & histamine \\
\hline Hert & hypocretin (orexin) \\
\hline HCRT1 & hypocretin 1 peptide (orexin-A peptide) \\
\hline HCRT2 & hypocretin 2 peptide (orexin-B peptide) \\
\hline HCRTR1 & hypocretin receptor 1 (orexin- 1 receptor, $\mathrm{OX}_{1} \mathrm{R}$ ) \\
\hline HCRTR2 & hypocretin receptor 2 (orexin- 2 receptor, $\mathrm{OX}_{2} \mathrm{R}$ ) \\
\hline GHB & gammahydroxybutyrate (sodium oxybate) \\
\hline HLA & human leukocyte antigen \\
\hline IVIg & intravenous immunoglobin \\
\hline $\mathbf{L C}$ & locus coeruleus \\
\hline LDT & laterodorsal tegmental nucleus \\
\hline МCH & melanin-concentrating hormone \\
\hline MM & medial medulla \\
\hline mPFC & medial prefrontal cortex \\
\hline MSLT & Multiple Sleep Latency Test \\
\hline MWT & Maintenance of Wakefulness Test \\
\hline $\mathbf{N E}$ & norepinephrine \\
\hline NREM & non-rapid eye movement sleep \\
\hline
\end{tabular}

Prog Neurobiol. Author manuscript; available in PMC 2018 May 01. 
PANDAS pediatric autoimmune neuropsychiatric disorders associated with streptococcal infections

PFH perifornical nucleus

PPT pedunculopontine tegmental nucleus

rAAV recombinant adeno-associated virus

REM Rapid eye movement sleep

SLD sublaterodorsal nucleus

SNRI serotonergic and noradrenergic reuptake inhibitor

SOREMP sleep-onset REM period

SSRI selective serotonergic reuptake inhibitor

$T_{\mathbf{b}} \quad$ core body temperature

TetO tetracycline operator

TM tuberomammillary nucleus

TRIB2 tribbles homologue 2

tTA tetracycline transactivator

VEH Vehicle

vlPAG ventrolateral periaqueductal gray

WT Wild type

ZT Zeitgeber time

\section{References}

Absalom N, Eghorn LF, Villumsen IS, Karim N, Bay T, Olsen JV, Knudsen GM, Brauner-Osborne H, Frolund B, Clausen RP, Chebib M, Wellendorph P. alpha4betadelta GABAA receptors are highaffinity targets for gamma-hydroxybutyric acid (GHB). Proc. Natl. Acad. Sci. U.S.A. 2012; 109:13404-13409. [PubMed: 22753476]

Ahmed SS, Schur PH, MacDonald NE, Steinman L. Narcolepsy, 2009 A(H1N1) pandemic influenza, and pandemic influenza vaccinations: what is known and unknown about the neurological disorder, the role for autoimmunity, and vaccine adjuvants. J. Autoimmun. 2014; 50:1-11. [PubMed: 24559657]

Ahmed SS, Volkmuth W, Duca J, Corti L, Pallaoro M, Pezzicoli A, Karle A, Rigat F, Rappuoli R, Narasimhan V, Julkunen I, Vuorela A, Vaarala O, Nohynek H, Pasini FL, Montomoli E, Trombetta C, Adams CM, Rothbard J, Steinman L. Antibodies to influenza nucleoprotein cross-react with human hypocretin receptor 2. Sci. Transl. Med. 2015; 7:294ra105.

Akimoto H, Honda Y, Takahashi Y. Pharmacotherapy in narcolepsy. Dis. Nerv. Syst. 1960; 21:704706. [PubMed: 13681922]

Alexander SP, Benson HE, Faccenda E, Pawson AJ, Sharman JL, Spedding M, Peters JA, Harmar AJ, Collaborators C. The Concise Guide to PHARMACOLOGY 2013/14: G protein-coupled receptors. Br. J. Pharmacol. 2013; 170:1459-1581. [PubMed: 24517644] 
Andlauer O, Moore H, Hong t. Dauvilliers SC, Kanbayashi Y, Nishino T, Han S, Silber F, Rico MH, Einen T, Kornum M, Jennum BR, Knudsen P, Nevsimalova S, Poli S, Plazzi F, Mignot GE. Predictors of hypocretin (orexin) deficiency in narcolepsy without cataplexy. Sleep. 2012; 35:12471255. [PubMed: 22942503]

Anic-Labat S, Guilleminault C, Kraemer HC, Meehan J, Arrigoni J, Mignot E. Validation of a cataplexy questionnaire in 983 sleep-disorders patients. Sleep. 1999; 22:77-87. [PubMed: 9989368]

Aran A, Lin L, Nevsimalova S, Plazzi G, Hong SC, Weiner K, Zeitzer J, Mignot E. Elevated antistreptococcal antibodies in patients with recent narcolepsy onset. Sleep. 2009; 32:979-983. [PubMed: 19725248]

Arango MT, Kivity S, Shoenfeld Y. Is narcolepsy a classical autoimmune disease? Pharmacol. Res. 2015; 92:6-12. [PubMed: 25447795]

Aserinsky E, Kleitman N. Regularly occurring periods of eye motility, and concomitant phenomena, during sleep. Science. 1953; 118:273-274. [PubMed: 13089671]

Aston-Jones G, Bloom FE. Activity of norepinephrine-containing locus coeruleus neurons in behaving rats anticipates fluctuations in the sleep-waking cycle. J. Neurosci. 1981; 1:876-886. [PubMed: 7346592]

Babcock DA, Narver EL, Dement WC, Mitler MM. Effects of imipramine, chlorimipramine, and fluoxetine on cataplexy in dogs. Pharmacol. Biochem. Behav. 1976; 5:599-602. [PubMed: 1035802]

Baier PC, Hallschmid M, Seeck-Hirschner M, Weinhold SL, Burkert S, Diessner N, Goder R, Aldenhoff JB, Hinze-Selch D. Effects of intranasal hypocretin-1 (orexin A) on sleep in narcolepsy with cataplexy. Sleep Med. 2011; 12:941-946. [PubMed: 22036605]

Baker, TL., Dement, WC. Canine narcolepsy-cataplexy syndrome: evidence for an inherited monoaminergic-cholinergic imbalance.. In: McGinty, DJ.Drucker-Colín, RR.Morrison, A., Parmeggiani, PL., editors. Brain Mechanisms of Sleep. Raven Press; New York: 1985. p. 199-234.

Baker TL, Guilleminault C, Nino-Murcia G, Dement WC. Comparative polysomnographic study of narcolepsy and idiopathic central nervous system hypersomnia. Sleep. 1986; 9:232-242. [PubMed: 3704448]

Bardage C, Persson I, Ortqvist A, Bergman U, Ludvigsson JF, Granath F. Neurological and autoimmune disorders after vaccination against pandemic influenza A (H1N1) with a monovalent adjuvanted vaccine: population based cohort study in Stockholm, Sweden. Br. Med. J. 2011; 343:d5956. [PubMed: 21994316]

Bassetti C, Aldrich MS. Narcolepsy Neurol. Clin. 1996; 14:545-571. [PubMed: 8871976]

Bastianini S, Silvani A, Berteotti C, Lo Martire V, Zoccoli G. High-amplitude theta wave bursts during REM sleep and cataplexy in hypocretin-deficient narcoleptic mice. J. Sleep Res. 2012; 21:185188. [PubMed: 21883592]

Bastuji H, Jouvet M. Successful treatment of idiopathic hypersomnia and narcolepsy with modafinil. Prog. Neuropsychopharmacol. Biol. Psychiatry. 1988; 12:695-700. [PubMed: 2906157]

Baumann CR, Mignot E, Lammers GJ, Overeem S, Arnulf I, Rye D, Dauvilliers Y, Honda M, Owens JA, Plazzi G, Scammell TE. Challenges in diagnosing narcolepsy without cataplexy: a consensus statement. Sleep. 2014; 37:1035-1042. [PubMed: 24882898]

Beitinger PA, Fulda S, Dalal MA, Wehrle R, Keckeis M, Wetter TC, Han F, Pollmacher T, Schuld A. Glucose tolerance in patients with narcolepsy. Sleep. 2012; 35:231-236. [PubMed: 22294813]

Bergman P, Adori C, Vas S, Kai-Larsen Y, Sarkanen T, Cederlund A, Agerberth B, Julkunen I, Horvath B, Kostyalik D, Kalmar L, Bagdy G, Huutoniemi A, Partinen M, Hokfelt T. Narcolepsy patients have antibodies that stain distinct cell populations in rat brain and influence sleep patterns. Proc. Natl. Acad. Sci. U.S.A. 2014; 111:E3735-E3744. [PubMed: 25136085]

Berry-Kravis EM, Hessl D, Rathmell B, Zarevics P, Cherubini M, Walton-Bowen K, Mu Y, Nguyen DV, Gonzalez-Heydrich J, Wang PP, Carpenter RL, Bear MF, Hagerman RJ. Effects of STX209 (arbaclofen) on neurobehavioral function in children and adults with fragile $\mathrm{X}$ syndrome: $\mathrm{a}$ randomized, controlled, phase 2 trial. Sci. Transl. Med. 2012; 4:152, ra127.

Besset A, Tafti M, Nobile L, Billiard M. Homeostasis and narcolepsy. Sleep. 1994; 17:S29-S34. [PubMed: 7701197]

Prog Neurobiol. Author manuscript; available in PMC 2018 May 01. 
Beuckmann CT, Sinton CM, Williams SC, Richardson JA, Hammer RE, Sakurai T, Yanagisawa M. Expression of a poly-glutamine-ataxin-3 transgene in orexin neurons induces narcolepsy-cataplexy in the rat. J. Neurosci. 2004; 24:4469-4477. [PubMed: 15128861]

Black J, Pardi D, Hornfeldt CS, Inhaber N. The nightly use of sodium oxybate is associated with a reduction in nocturnal sleep disruption: a double-blind, placebo-controlled study in patients with narcolepsy. J. Clin. Sleep Med. 2010; 6:596-602. [PubMed: 21206549]

Black JL 3rd, Silber MH, Krahn LE, Avula RK, Walker DL, Pankratz VS, Fredrickson PA, Slocumb NL. Studies of humoral immunity to preprohypocretin in human leukocyte antigen DQB $1 * 0602-$ positive narcoleptic subjects with cataplexy. Biol Psychiatry. 2005; 58:504-509. [PubMed: 16043129]

Black J, Swick T, Feldman N, Doekel J, Khayrallah R, Bream M, Ruoff GC. Oral JZP-110 (ADXN05) for the treatment of excessive daytime sleepiness in adults with narcolepsy: results of a randomised, double-blind, placebo-controlled trial. J. Sleep Res. 2014a; 23(Supp. 1):S32-S33.

Black SW, Morairty SR, Chen TM, Leung AK, Wisor JP, Yamanaka A, Kilduff TS. GABAB agonism promotes sleep and reduces cataplexy in murine narcolepsy. J. Neurosci. 2014b; 34:6485-6494. [PubMed: 24806675]

Black SW, Morairty SR, Fisher SP, Chen TM, Warrier DR, Kilduff TS. Almorexant promotes sleep and exacerbates cataplexy in a murine model of narcolepsy. Sleep. 2013; 36:325-336. [PubMed: 23449602]

Blanco-Centurion C, Liu M, Konadhode R, Pelluru D, Shiromani PJ. Effects of orexin gene transfer in the dorsolateral pons in orexin knockout mice. Sleep. 2013; 36:31-40. [PubMed: 23288969]

Blouin AM, Thannickal TC, Worley PF, Baraban JM, Reti IM, Siegel JM. Narp immunostaining of human hypocretin (orexin) neurons: loss in narcolepsy. Neurology. 2005; 65:1189-1192. [PubMed: 16135770]

Boehme RE, Baker TL, Mefford IN, Barchas JD, Dement WC, Ciaranello RD. Narcolepsy: cholinergic receptor changes in an animal model. Life Sci. 1984; 34:1825-1828. [PubMed: 6539848]

Bogan RK, Feldman NT, Lankford A, Khayrallah MA. A double-blind, placebo-controlled, randomized, cross-over study of the efficacy and safety of ADX-N05 for the treatment of excessive daytime sleepiness in adult subjects with narcolepsy. Sleep. 2013; 36:A257.

Boissard R, Fort P, Gervasoni D, Barbagli B, Luppi PH. Localization of the GABAergic and nonGABAergic neurons projecting to the sublaterodorsal nucleus and potentially gating paradoxical sleep onset. Eur. J. Neurosci. 2003; 18:1627-1639. [PubMed: 14511341]

Boissard R, Gervasoni D, Schmidt MH, Barbagli B, Fort P, Luppi PH. The rat ponto-medullary network responsible for paradoxical sleep onset and maintenance: a combined microinjection and functional neuroanatomical study. Eur. J. Neurosci. 2002; 16:1959-1973. [PubMed: 12453060]

Borbely AA, Tobler I, Hanagasioglu M. Effect of sleep deprivation on sleep and EEG power spectra in the rat. Behav. Brain Res. 1984; 14:171-182. [PubMed: 6525241]

Bosch OG, Quednow BB, Seifritz E, Wetter TC. Reconsidering GHB: orphan drug or new model antidepressant? J. Psychopharmacol. 2012; 26:618-628. [PubMed: 21926421]

Boscolo-Berto R, Viel G, Montagnese S, Raduazzo DI, Ferrara SD, Dauvilliers Y. Narcolepsy and effectiveness of gamma-hydroxybutyrate (GHB): a systematic review and meta-analysis of randomized controlled trials. Sleep Med. Rev. 2012; 16:431-443. [PubMed: 22055895]

Bowersox SS, Kilduff TS, Faull KF, Zeller-DeAmicis L, Dement WC, Ciaranello RD. Brain dopamine receptor levels elevated in canine narcolepsy. Brain Res. 1987; 402:44-48. [PubMed: 3828787]

Bowersox SS, Kilduff TS, Kaitin KI, Dement WC, Ciaranello RD. Brain benzodiazepine receptor characteristics in canine narcolepsy. Sleep. 1986; 9:111-115. [PubMed: 3010425]

Brooks PL, Peever JH. Glycinergic and GABA(A)-mediated inhibition of somatic motoneurons does not mediate rapid eye movement sleep motor atonia. J. Neurosci. 2008; 28:3535-3545. [PubMed: 18385312]

Brooks PL, Peever JH. Identification of the transmitter and receptor mechanisms responsible for REM sleep paralysis. J. Neurosci. 2012; 32:9785-9795. [PubMed: 22815493]

Broughton R, Dunham W, Newman J, Lutley K, Duschesne P, Rivers M. Ambulatory 24 hour sleepwake monitoring in narcolepsy-cataplexy compared to matched controls. Electroencephalogr. Clin. Neurophysiol. 1988; 70:473-481. [PubMed: 2461281] 
Broughton R, Ghanem Q, Hishikawa Y, Sugita Y, Nevsimalova S, Roth B. Life effects of narcolepsy: relationships to geographic origin (North American Asian or European) and to other patient and illness variables. Can. J. Neurol. Sci. 1983; 10:100-104. [PubMed: 6861006]

Broughton R, Valley V, Aguirre M, Roberts J, Suwalski W, Dunham W. Excessive daytime sleepiness and the pathophysiology of narcolepsy-cataplexy: a laboratory perspective. Sleep. 1986; 9:205215. [PubMed: 3704444]

Brown MA, Guilleminault C. A review of sodium oxybate and baclofen in the treatment of sleep disorders. Curr. Pharm. Des. 2011; 17:1430-1435. [PubMed: 21476957]

Brown RE, Basheer R, McKenna JT, Strecker RE, McCarley RW. Control of sleep and wakefulness. Physiol. Rev. 2012; 92:1087-1187. [PubMed: 22811426]

Brown RE, Winston S, Basheer R, Thakkar MM, McCarley RW. Electrophysiological characterization of neurons in the dorsolateral pontine rapid-eye-movement sleep induction zone of the rat: Intrinsic membrane properties and responses to carbachol and orexins. Neuroscience. 2006; 143:739-755. [PubMed: 17008019]

Burgess CR, Oishi Y, Mochizuki T, Peever JH, Scammell TE. Amygdala lesions reduce cataplexy in orexin knock-out mice. J. Neurosci. 2013; 33:9734-9742. [PubMed: 23739970]

Burgess CR, Peever JH. A noradrenergic mechanism functions to couple motor behavior with arousal state. Curr. Biol. 2013; 23:1719-1725. [PubMed: 23993842]

Burgess CR, Scammell TE. Narcolepsy: neural mechanisms of sleepiness and cataplexy. J. Neurosci. 2012; 32:12305-12311. [PubMed: 22956821]

Burgess CR, Tse G, Gillis L, Peever JH. Dopaminergic regulation of sleep and cataplexy in a murine model of narcolepsy. Sleep. 2010; 33:1295-1304. [PubMed: 21061851]

Burlet S, Tyler CJ, Leonard CS. Direct and indirect excitation of laterodorsal tegmental neurons by Hypocretin/Orexin peptides: implications for wakefulness and narcolepsy. J. Neurosci. 2002; 22:2862-2872. [PubMed: 11923451]

Calabro S, Tritto E, Pezzotti A, Taccone M, Muzzi A, Bertholet S, De Gregorio E, O'Hagan DT, Baudner B, Seubert A. The adjuvant effect of MF59 is due to the oil-in-water emulsion formulation, none of the individual components induce a comparable adjuvant effect. Vaccine. 2013; 31:3363-3369. [PubMed: 23684834]

Canellas F, Lin L, Julia MR, Clemente A, Vives-Bauza C, Ollila HM, Hong SC, Arboleya SM, Einen MA, Faraco J, Fernandez-Vina M, Mignot E. Dual cases of type 1 narcolepsy with schizophrenia and other psychotic disorders. J. Clin. Sleep Med. 2014; 10:1011-1018. [PubMed: 25142772]

Carlander B, Eliaou JF, Billiard M. Autoimmune hypothesis in narcolepsy. Neurophysiol. Clin. 1993; 23:15-22. [PubMed: 8446070]

CDER. The Voice of the Patient: Narcolepsy, Ed. Silver Spring; MD, U.S. FDA: 2013. p. 1-25.

Ch'ng SS, Lawrence AJ. Distribution of the orexin-1 receptor (OX1R) in the mouse forebrain and rostral brainstem: a characterisation of OX1R-eGFP mice. J. Chem. Neuroanat. 2015; 66-67V-:19.

Chabas D, Foulon C, Gonzalez J, Nasr M, Lyon-Caen O, Willer JC, Derenne JP, Arnulf I. Eating disorder and metabolism in narcoleptic patients. Sleep. 2007; 30:1267-1273. [PubMed: 17969460]

Chang K, Frankovich J, Cooperstock M, Cunningham MW, Latimer ME, Murphy TK, Pasternack M, Thienemann M, Williams K, Walter J, Swedo SE. Clinical evaluation of youth with pediatric acute-onset neuropsychiatric syndrome (PANS): recommendations from the 2013 PANS Consensus Conference. J. Child Adolesc. Psychopharmacol. 2015; 25:3-13. [PubMed: 25325534]

Chase MH, Soja PJ, Morales FR. Evidence that glycine mediates the postsynaptic potentials that inhibit lumbar motoneurons during the atonia of active sleep. J. Neurosci. 1989; 9:743-751. [PubMed: 2926479]

Chemelli RM, Willie JT, Sinton CM, Elmquist JK, Scammell T, Lee C, Richardson JA, Williams SC, Xiong Y, Kisanuki Y, Fitch TE, Nakazato M, Hammer RE, Saper CB, Yanagisawa M. Narcolepsy in orexin knockout mice: molecular genetics of sleep regulation. Cell. 1999; 98:437-451. [PubMed: 10481909]

Clark EL, Baumann CR, Cano G, Scammell TE, Mochizuki T. Feeding-elicited cataplexy in orexin knockout mice. Neuroscience. 2009; 161:970-977. [PubMed: 19362119] 
Crochet S, Onoe H, Sakai K. A potent non-monoaminergic paradoxical sleep inhibitory system: a reverse microdialysis and single-unit recording study. Eur. J. Neurosci. 2006; 24:1404-1412. [PubMed: 16987225]

Crocker A, Espana RA, Papadopoulou M, Saper CB, Faraco J, Sakurai T, Honda M, Mignot E, Scammell TE. Concomitant loss of dynorphin NARP, and orexin in narcolepsy. Neurology. 2005; 65:1184-1188. [PubMed: 16247044]

Cruz HG, Ivanova T, Lunn ML, Stoffel M, Slesinger PA, Luscher C. Bidirectional effects of GABA(B) receptor agonists on the mesolimbic dopamine system. Nat. Neurosci. 2004; 7:153-159. [PubMed: $14745451]$

Cvetkovic-Lopes V, Bayer L, Dorsaz S, Maret S, Pradervand S, Dauvilliers Y, Lecendreux M, Lammers GJ, Donjacour CE, Du Pasquier RA, Pfister C, Petit B, Hor H, Muhlethaler M, Tafti M. Elevated Tribbles homolog 2-specific antibody levels in narcolepsy patients. J. Clin. Invest. 2010; 120:713-719. [PubMed: 20160349]

Daan S, Beersma DG, Borbely AA. Timing of human sleep: recovery process gated by a circadian pacemaker. Am. J. Physiol. 1984; 246:R161-R183. [PubMed: 6696142]

Dahmen N, Becht J, Engel A, Thommes M, Tonn P. Prevalence of eating disorders and eating attacks in narcolepsy. Neuropsychiatr. Dis. Treat. 2008; 4:257-261. [PubMed: 18728824]

Dahmen N, Bierbrauer J, Kasten M. Increased prevalence of obesity in narcoleptic patients and relatives. Eur. Arch. Psychiatry Clin. Neurosci. 2001; 251:85-89. [PubMed: 11407443]

Dahmen N, Tonn P, Messroghli L, Ghezel-Ahmadi D, Engel A. Basal metabolic rate in narcoleptic patients. Sleep. 2009; 32:962-964. [PubMed: 19639760]

Dantz B, Edgar DM, Dement WC. Circadian rhythms in narcolepsy: studies on a 90 min day. Electroencephalogr. Clin. Neurophysiol. 1994; 90:24-35. [PubMed: 7509271]

Darwinkel A, Stanic D, Booth LC, May CN, Lawrence AJ, Yao ST. Distribution of orexin-1 receptorgreen fluorescent protein- (OX1-GFP) expressing neurons in the mouse brain stem and pons: colocalization with tyrosine hydroxylase and neuronal nitric oxide synthase. Neuroscience. 2014; 278:253-264. [PubMed: 25168728]

Date Y, Ueta Y, Yamashita H, Yamaguchi H, Matsukura S, Kangawa K, Sakurai T, Yanagisawa M, Nakazato M. Orexins, orexigenic hypothalamic peptides, interact with autonomic, neuroendocrine and neuroregulatory systems. Proc. Natl. Acad. Sci. U.S.A. 1999; 96:748-753. [PubMed: 9892705]

Dauvilliers Y, Abril B, Mas E, Michel F, Tafti M. Normalization of hypocretin-1 in narcolepsy after intravenous immunoglobulin treatment. Neurology. 2009; 73:1333-1334. [PubMed: 19841387]

Dauvilliers Y, Arnulf I, Lecendreux M, Monaca Charley C, Franco P, Drouot X, d'Ortho MP, Launois S, Lignot S, Bourgin P, Nogues B, Rey M, Bayard S, Scholz S, Lavault S, Tubert-Bitter P, Saussier C, Pariente A. a Increased risk of narcolepsy in children and adults after pandemic H1N1 vaccination in France. Brain. 2013a; 136:2486-2496. [PubMed: 23884811]

Dauvilliers Y, Bassetti C, Lammers GJ, Arnulf I, Mayer G, Rodenbeck A, Lehert P, Ding CL, Lecomte JM, Schwartz JC. Pitolisant versus placebo or modafinil in patients with narcolepsy: a doubleblind, randomised trial. Lancet Neurol. 2013b; 12:1068-1075. [PubMed: 24107292]

Dauvilliers Y, Carlander B, Rivier F, Touchon J, Tafti M. Successful management of cataplexy with intravenous immunoglobulins at narcolepsy onset. Ann. Neurol. 2004; 56:905-908. [PubMed: 15562415]

Dauvilliers Y, Jaussent I, Krams B, Scholz S, Lado S, Levy P, Pepin JL. Non-dipping blood pressure profile in narcolepsy with cataplexy. PLoS One. 2012; 7:e38977. [PubMed: 22768053]

Dauvilliers Y, Montplaisir J, Molinari N, Carlander B, Ondze B, Besset A, Billiard M. Age at onset of narcolepsy in two large populations of patients in France and Quebec. Neurology. 2001; 57:20292033. [PubMed: 11739821]

Dauvilliers Y, Jaussent I, Lecendreux M, Scholz S, Bayard S, Cristol JP, Blain H, Dupuy A.M.a. Cerebrospinal fluid and serum cytokine profiles in narcolepsy with cataplexy: a case-control study. Brain Behav. Immun. 2014a; 37:260-266. [PubMed: 24394344]

Dauvilliers Y, Siegel JM, Lopez R, Torontali ZA, Peever J.H.b. Cataplexy-clinical aspects, pathophysiology and management strategy. Nat. Rev. Neurol. 2014b; 10(7):386-395. [PubMed: 24890646] 
De la Herran-Arita AK, Kornum BR, Mahlios J, Jiang W, Lin L, Hou T, Macaubas C, Einen M, Plazzi G, Crowe C, Newell EW, Davis MM, Mellins ED, Mignot E. CD4+ T cell autoimmunity to hypocretin/orexin and cross-reactivity to a 2009 H1N1 influenza A epitope in narcolepsy. Sci. Transl. Med. 2013; 5:216ra176.

De la Herran-Arita AK, Kornum BR, Mahlios J, Jiang W, Lin L, Hou T, Macaubas C, Einen M, Plazzi G, Crowe C, Newell EW, Davis MM, Mellins ED, Mignot E. Retraction of the research article: "CD4(+) T cell autoimmunity to hypocretin/orexin and cross-reactivity to a 2009 H1N1 influenza A epitope in narcolepsy”. Sci. Transl. Med. 2014; 6:247rt241.

De La Herran-Arita AK, Zomosa-Signoret VC, Millan-Aldaco DA, Palomero-Rivero M, GuerraCrespo M, Drucker-Colin R, Vidaltamayo R. Aspects of the narcolepsy-cataplexy syndrome in O/E3-null mutant mice. Neuroscience. 2011; 183:134-143. [PubMed: 21435382]

de Lecea L, Kilduff TS, Peyron C, Gao X, Foye PE, Danielson PE, Fukuhara C, Battenberg EL, Gautvik VT, Bartlett FS 2nd, Frankel WN, van den Pol AN, Bloom FE, Gautvik KM, Sutcliffe JG. The hypocretins: hypothalamus-specific peptides with neuroexcitatory activity. Proc. Natl. Acad. Sci. U.S.A. 1998; 95:322-327. [PubMed: 9419374]

Deadwyler SA, Porrino L, Siegel JM, Hampson RE. Systemic and nasal delivery of orexin-A (Hypocretin-1) reduces the effects of sleep deprivation on cognitive performance in nonhuman primates. J. Neurosci. 2007; 27:14239-14247. [PubMed: 18160631]

Dean RR, Kilduff TS, Dement WC, Grumet FC. Narcolepsy without unique MHC class II antigen association: studies in the canine model. Hum. Immunol. 1989; 25:27-35. [PubMed: 2523880]

Delashaw JB Jr. Foutz AS, Guilleminault C, Dement WC. Cholinergic mechanisms and cataplexy in dogs. Exp. Neurol. 1979; 66:745-757. [PubMed: 573697]

Dement W, Kleitman N. The relation of eye movements during sleep to dream activity: an objective method for the study of dreaming. J. Exp. Psychol. 1957; 53:339-346. [PubMed: 13428941]

Dement W, Rechtschaffen A, Gulevich G. The nature of the narcoleptic sleep attack. Neurology. 1966; 16:18-33. [PubMed: 5948003]

Dement, WC. Historical aspects of narcolepsy.. In: Bassetti, CL.Billiard, M., Mignot, E., editors. Narcolepsy and Hypersomnia. Informa Healthcare USA; New York, NY: 2007. p. 1-5.

Dhuria SV, Hanson LR, Frey WH. 2nd Intranasal drug targeting of hypocretin-1 (orexin-A) to the central nervous system. J. Pharm. Sci. 2009; 98:2501-2515. [PubMed: 19025760]

Donadio V, Liguori R, Vandi S, Pizza F, Dauvilliers Y, Leta V, Giannoccaro MP, Baruzzi A, Plazzi G. Lower wake resting sympathetic and cardiovascular activities in narcolepsy with cataplexy. Neurology. 2014; 83:1080-1086. [PubMed: 25098533]

Donjacour CE, Aziz NA, Overeem S, Kalsbeek A, Pijl H, Lammers GJ. Glucose and fat metabolism in narcolepsy and the effect of sodium oxybate: a hyperinsulinemic-euglycemic clamp study. Sleep. 2014; 37:795-801. [PubMed: 24899766]

Donjacour CE, Pardi D, Aziz NA, Frolich M, Roelfsema F, Overeem S, Pijl H, Lammers GJ. Plasma total ghrelin and leptin levels in human narcolepsy and matched healthy controls: basal concentrations and response to sodium oxybate. J. Clin. Sleep Med. 2013; 9:797-803. [PubMed: 23946710]

Doyle JB, Daniels LE. Narcolepsy: results of treatment with ephedrine sulphate. J. Am. Med. Assoc. 1932; 98:542-545.

Dreifuss FE, Flynn DV. Narcolepsy in a horse. J. Am. Vet. Med. Assoc. 1984; 184:131-132. [PubMed: 6538191]

Duffy J, Weintraub E, Vellozzi C, DeStefano F, Vaccine Safety D. Narcolepsy and influenza A(H1N1) pandemic 2009 vaccination in the United States. Neurology. 2014; 83:1823-1830. [PubMed: 25320099]

Edgar DM, Dement WC, Fuller CA. Effect of SCN lesions on sleep in squirrel monkeys: evidence for opponent processes in sleep-wake regulation. J. Neurosci. 1993; 13:1065-1079. [PubMed: 8441003]

Edgar DM, Seidel WF. Modafinil induces wakefulness without intensifying motor activity or subsequent rebound hypersomnolence in the rat. J. Pharmacol. Exp. Ther. 1997; 283:757-769. [PubMed: 9353396] 
Eichler, AF. International Classification of Sleep Disorders, Ed. American Academy of Sleep Medicine; Darien, IL: 2014.

Espana RA, McCormack SL, Mochizuki T, Scammell TE. Running promotes wakefulness and increases cataplexy in orexin knockout mice. Sleep. 2007; 30:1417-1425. [PubMed: 18041476]

Faraco J, Lin L, Kornum BR, Kenny EE, Trynka G, Einen M, Rico TJ, Lichtner P, Dauvilliers Y, Arnulf I, Lecendreux M, Javidi S, Geisler P, Mayer G, Pizza F, Poli F, Plazzi G, Overeem S, Lammers GJ, Kemlink D, Sonka K, Nevsimalova S, Rouleau G, Desautels A, Montplaisir J, Frauscher B, Ehrmann L, Hogl B, Jennum P, Bourgin P, Peraita-Adrados R, Iranzo A, Bassetti C, Chen WM, Concannon P, Thompson SD, Damotte V, Fontaine B, Breban M, Gieger C, Klopp N, Deloukas P, Wijmenga C, Hallmayer J, Onengut-Gumuscu S, Rich SS, Winkelmann J, Mignot E. ImmunoChip study implicates antigen presentation to T cells in narcolepsy. PLoS Genet. 2013; 9:e1003270. [PubMed: 23459209]

Faull KF, Barchas JD, Foutz AS, Dement WC, Holman RB. Monoamine metabolite concentrations in the cerebrospinal fluid of normal and narcoleptic dogs. Brain Res. 1982; 242:137-143. [PubMed: 6179569]

Faull KF, Zeller-DeAmicis LC, Radde L, Bowersox SS, Baker TL, Kilduff TS, Dement WC. Biogenic amine concentrations in the brains of normal and narcoleptic canines: current status. Sleep. 1986; 9:107-110. [PubMed: 3704432]

Ferini-Strambi L, Spera A, Oldani A, Zucconi M, Bianchi A, Cerutti S, Smirne S. Autonomic function in narcolepsy: power spectrum analysis of heart rate variability. J. Neurol. 1997; 244:252-255. [PubMed: 9112594]

Fortuyn HA, Swinkels S, Buitelaar J, Renier WO, Furer JW, Rijnders CA, Hodiamont PP, Overeem S. High prevalence of eating disorders in narcolepsy with cataplexy: a case-control study. Sleep. 2008; 31:335-341. [PubMed: 18363309]

Foutz AS, Mitler MM, Cavalli-Sforza LL, Dement WC. Genetic factors in canine narcolepsy. Sleep. 1979; 1:413-421. [PubMed: 574310]

Frauscher B, Ehrmann L, Mitterling T, Gabelia D, Gschliesser V, Brandauer E, Poewe W, Hogl B. Delayed diagnosis, range of severity, and multiple sleep comorbidities: a clinical and polysomnographic analysis of 100 patients of the innsbruck narcolepsy cohort. J. Clin. Sleep Med. 2013; 9:805-812. [PubMed: 23946711]

Fronczek R, Overeem S, Lammers GJ, van Dijk JG, Van Someren EJ. Altered skin-temperature regulation in narcolepsy relates to sleep propensity. Sleep. 2006; 29:1444-1449. [PubMed: 17162991]

Fronczek R, Overeem S, Reijntjes R, Lammers GJ, van Dijk JG, Pijl H. Increased heart rate variability but normal resting metabolic rate in hypocretin/orexin-deficient human narcolepsy. J. Clin. Sleep Med. 2008a; 4:248-254. [PubMed: 18595438]

Fronczek R, Raymann RJ, Overeem S, Romeijn N, van Dijk JG, Lammers GJ, Van Someren EJ. Manipulation of skin temperature improves nocturnal sleep in narcolepsy. J. Neurol. Neurosurg. Psychiatry. 2008b; 79:1354-1357. [PubMed: 18653548]

Fujiki N, Cheng T, Yoshino F, Nishino S. Specificity of direct transition from wake to REM sleep in orexin/ataxin-3 transgenic narcoleptic mice. Exp. Neurol. 2009; 217:46-54. [PubMed: 19416673]

Funato H, Tsai AL, Willie JT, Kisanuki Y, Williams SC, Sakurai T, Yanagisawa M. Enhanced orexin receptor-2 signaling prevents diet-induced obesity and improves leptin sensitivity. Cell Metab. 2009; 9:64-76. [PubMed: 19117547]

Gélineau J. De la Narcolepsie. Gaz Hop (Paris). 1880; 53:535-637.

Gerashchenko D, Murillo-Rodriguez E, Lin L, Xu M, Hallett L, Nishino S, Mignot E, Shiromani PJ. Relationship between CSF hypocretin levels and hypocretin neuronal loss. Exp. Neurol. 2003; 184:1010-1016. [PubMed: 14769395]

Gerashchenko D, Salin-Pascual R, Shiromani PJ. Effects of hypocretinsaporin injections into the medial septum on sleep and hippocampal theta. Brain Res. 2001; 913:106-115. [PubMed: 11532254]

Golicki D, Bala MM, Niewada M, Wierzbicka A. Modafinil for narcolepsy: systematic review and meta-analysis. Med. Sci. Monit. 2010; 16:Ra177-Ra186. [PubMed: 20671626] 
Graus F, Saiz A, Dalmau J. Antibodies and neuronal autoimmune disorders of the CNS. J. Neurol. 2010; 257:509-517. [PubMed: 20035430]

Gray KA, Yates B, Seal RL, Wright MW, Bruford EA. 2015 Genenames.org: the HGNC resources in. Nucleic Acids Res. 2015; 43:D1079-D1085. [PubMed: 25361968]

Grimaldi D, Agati P, Pierangeli G, Franceschini C, Guaraldi P, Barletta G, Vandi S, Cevoli S, Plazzi G, Montagna P, Cortelli P. a Hypocretin deficiency in narcolepsy with cataplexy is associated with a normal body core temperature modulation. Chronobiol. Int. 2010a; 27:1596-1608. [PubMed: 20854137]

Grimaldi D, Pierangeli G, Barletta G, Terlizzi R, Plazzi G, Cevoli S, Franceschini C, Montagna P, Cortelli P. b Spectral analysis of heart rate variability reveals an enhanced sympathetic activity in narcolepsy with cataplexy. Clin. Neurophysiol. 2010b; 121:1142-1147. [PubMed: 20181520]

Grimaldi D, Calandra-Buonaura G, Provini F, Agati P, Pierangeli G, Franceschini C, Barletta G, Plazzi G, Montagna P, Cortelli P. Abnormal sleep-cardiovascular system interaction in narcolepsy with cataplexy: effects of hypocretin deficiency in humans. Sleep. 2012; 35:519-528. [PubMed: 22467990]

Guilleminault, C., Cao, MT. Narcolepsy: Diagnosis and management.. In: Kryger, MH.Roth, T., Dement, WC., editors. Principles and Practice of Sleep Medicine. Elsevier Saunders; St. Louis, Missouri: 2011. p. 957-968.

Guilleminault, C., Lee, JH., Arias, V. Cataplexy.. In: Bassetti, CL.Billiard, M., Mignot, E., editors. Narcolepsy and Hypersomnia. Informa Healthcare USA; New York, NY: 2007. p. 49-62.

Gulyani S, Wu MF, Nienhuis R, John J, Siegel JM. Cataplexy-related neurons in the amygdala of the narcoleptic dog. Neuroscience. 2002; 112:355-365. [PubMed: 12044453]

Hallmayer J, Faraco J, Lin L, Hesselson S, Winkelmann J, Kawashima M, Mayer G, Plazzi G, Nevsimalova S, Bourgin P, Hong SC, Honda Y, Honda M, Hogl B, Longstreth WT Jr. Montplaisir J, Kemlink D, Einen M, Chen J, Musone SL, Akana M, Miyagawa T, Duan J, Desautels A, Erhardt C, Hesla PE, Poli F, Frauscher B, Jeong JH, Lee SP, Ton TG, Kvale M, Kolesar L, Dobrovolna M, Nepom GT, Salomon D, Wichmann HE, Rouleau GA, Gieger C, Levinson DF, Gejman PV, Meitinger T, Young T, Peppard P, Tokunaga K, Kwok PY, Risch N, Mignot E. Narcolepsy is strongly associated with the T-cell receptor alpha locus. Nat. Genet. 2009; 41:708-711. [PubMed: 19412176]

Han F, Faraco J, Dong XS, Ollila HM, Lin L, Li J, An P, Wang S, Jiang KW, Gao ZC, Zhao L, Yan H, Liu YN, Li QH, Zhang XZ, Hu Y, Wang JY, Lu YH, Lu CJ, Zhou W, Hallmayer J, Huang YS, Strohl KP, Pollmacher T, Mignot E. Genome wide analysis of narcolepsy in China implicates novel immune loci and reveals changes in association prior to versus after the 2009 H1N1 influenza pandemic. PLoS Genet. 2013a; 9:e1003880. [PubMed: 24204295]

Han F, Lin L, Li J, Dong XS, Mignot E. Decreased incidence of childhood narcolepsy 2 years after the 2009 H1N1 winter flu pandemic. Ann. Neurol. 2013b; 73:560. [PubMed: 23225098]

Han F, Lin L, Warby SC, Faraco J, Li J, Dong SX, An P, Zhao L, Wang LH, Li QY, Yan H, Gao ZC, Yuan Y, Strohl KP, Mignot E. Narcolepsy onset is seasonal and increased following the 2009 H1N1 pandemic in China. Ann. Neurol. 2011; 70:410-417. [PubMed: 21866560]

Hara J, Beuckmann CT, Nambu T, Willie JT, Chemelli RM, Sinton CM, Sugiyama F, Yagami K, Goto $\mathrm{K}$, Yanagisawa M, Sakurai T. Genetic ablation of orexin neurons in mice results in narcolepsy, hypophagia, and obesity. Neuron. 2001; 30:345-354. [PubMed: 11394998]

Hara J, Yanagisawa M, Sakurai T. Difference in obesity phenotype between orexin-knockout mice and orexin neuron-deficient mice with same genetic background and environmental conditions. Neurosci. Lett. 2005; 380:239-242. [PubMed: 15862893]

Harsh J, Peszka J, Hartwig G, Mitler M. Night-time sleep and daytime sleepiness in narcolepsy. J. Sleep Res. 2000; 9:309-316. [PubMed: 11012872]

Hasegawa E, Yanagisawa M, Sakurai T, Mieda M. Orexin neurons suppress narcolepsy via 2 distinct efferent pathways. J. Clin. Invest. 2014; 124:604-616. [PubMed: 24382351]

Heier MS, Jansson TS, Gautvik KM. Cerebrospinal fluid hypocretin 1 deficiency, overweight, and metabolic dysregulation in patients with narcolepsy. J. Clin. Sleep Med. 2011; 7:653-658. [PubMed: 22171205] 
Heister DS, Hayar A, Garcia-Rill E. Cholinergic modulation of GABAergic and glutamatergic transmission in the dorsal subcoeruleus: mechanisms for REM sleep control. Sleep. 2009; 32:1135-1147. [PubMed: 19750918]

Hishikawa Y, Ida H, Nakai K, Kaneko Z. Treatment of narcolepsy with imipramine (tofranil) and desmethylimipramine (pertofran). J. Neurol. Sci. 1966; 3:453-461. [PubMed: 4380880]

Hishikawa, Y., Shimizu, T. Historical aspects of the treatment for narcolepsy.. In: Bassetti, CL.Billiard, M., Mignot, E., editors. Narcolepsy and Hypersomnia. Informa Healthcare USA; New York, NY: 2007. p. 25-30.

Hobson JA, McCarley RW, Wyzinski PW. Sleep cycle oscillation: reciprocal discharge by two brainstem neuronal groups. Science. 1975; 189:55-58. [PubMed: 1094539]

Honda Y. Census of narcolepsy, cataplexy and sleep life among teenagers in Fujisawa City. Sleep Res. 1979; 8:191.

Honda Y, Doi Y, Ninomiya R, Ninomiya C. Increased frequency of non-insulin-dependent diabetes mellitus among narcoleptic patients. Sleep. 1986; 9:254-259. [PubMed: 3518018]

Huang YS, Guilleminault C. Narcolepsy: action of two gamma-aminobutyric acid type B agonists, baclofen and sodium oxybate. Pediatr. Neurol. 2009; 41:9-16. [PubMed: 19520267]

Huang ZL, Qu WM, Li WD, Mochizuki T, Eguchi N, Watanabe T, Urade Y, Hayaishi O. Arousal effect of orexin A depends on activation of the histaminergic system. Proc. Natl. Acad. Sci. U.S.A. 2001; 98:9965-9970. [PubMed: 11493714]

Hublin C, Partinen M, Heinonen EH, Puukka P, Salmi T. Selegiline in the treatment of narcolepsy. Neurology. 1994; 44:2095-2101. [PubMed: 7969965]

Hudgson P, Weightman D. Baclofen in the treatment of spasticity. Br. Med. J. 1971; 4:15-17. [PubMed: 4938243]

Hungs M, Fan J, Lin L, Lin X, Maki RA, Mignot E. Identification and functional analysis of mutations in the hypocretin (orexin) genes of narcoleptic canines. Genome Res. 2001; 11:531-539. [PubMed: 11282968]

Jacob L, Leib R, Ollila HM, Bonvalet M, Adams CM, Mignot E. Comparison of Pandemrix and Arepanrix, two pH1N1 AS03-adjuvanted vaccines differentially associated with narcolepsy development. Brain Behav. Immun. 2015; 47:44-57. [PubMed: 25452148]

Jennum P, Ibsen R, Knudsen S, Kjellberg J. Comorbidity and mortality of narcolepsy: a controlled retro- and prospective national study. Sleep. 2013; 36:835-840. [PubMed: 23729926]

Jensen K, Mody I. GHB depresses fast excitatory and inhibitory synaptic transmission via GABA(B) receptors in mouse neocortical neurons. Cereb. Cortex. 2001; 11:424-429. [PubMed: 11313294]

John J, Thannickal TC, McGregor R, Ramanathan L, Ohtsu H, Nishino S, Sakai N, Yamanaka A, Stone C, Cornford M, Siegel JM. Greatly increased numbers of histamine cells in human narcolepsy with cataplexy. Ann. Neurol. 2013; 74:786-793. [PubMed: 23821583]

John J, Wu MF, Boehmer LN, Siegel JM. Cataplexy-active neurons in the hypothalamus: implications for the role of histamine in sleep and waking behavior. Neuron. 2004; 42:619-634. [PubMed: 15157423]

Jouvet M, Michel F, Courjon J. [On a stage of rapid cerebral electrical activity in the course of physiological sleep]. C R Seances Soc. Biol. Fil. 1959; 153:1024-1028. [PubMed: 14408003]

Ju YE, Larson-Prior L, Duntley S. Changing demographics in REM sleep behavior disorder: possible effect of autoimmunity and antidepressants. Sleep Med. 2011; 12:278-283. [PubMed: 21317035]

Juji T, Satake M, Honda Y, Doi Y. HLA antigens in Japanese patients with narcolepsy: all the patients were DR2 positive. Tissue Antigens. 1984; 24:316-319. [PubMed: 6597978]

Kaitin KI, Kilduff TS, Dement WC. Evidence for excessive sleepiness in canine narcoleptics. Electroencephalogr. Clin. Neurophysiol. 1986a; 64:447-454. [PubMed: 2428595]

Kaitin KI, Kilduff TS, Dement WC. Sleep fragmentation in canine narcolepsy. Sleep. 1986b; 9:116119. [PubMed: 3704433]

Kalogiannis M, Grupke SL, Potter PE, Edwards JG, Chemelli RM, Kisanuki YY, Yanagisawa M, Leonard CS. Narcoleptic orexin receptor knockout mice express enhanced cholinergic properties in laterodorsal tegmental neurons. Eur. J. Neurosci. 2010; 32:130-142. [PubMed: 20576035]

Prog Neurobiol. Author manuscript; available in PMC 2018 May 01. 
Kalogiannis M, Hsu E, Willie JT, Chemelli RM, Kisanuki YY, Yanagisawa M, Leonard CS. Cholinergic modulation of narcoleptic attacks in double orexin receptor knockout mice. PLoS One. 2011; 6:e18697. [PubMed: 21533254]

Kantor S, Mochizuki T, Lops SN, Ko B, Clain E, Clark E, Yamamoto M, Scammell TE. Orexin gene therapy restores the timing and maintenance of wakefulness in narcoleptic mice. Sleep. 2013; 36:1129-1138. [PubMed: 23904672]

Kaupmann K, Cryan JF, Wellendorph P, Mombereau C, Sansig G, Klebs K, Schmutz M, Froestl W, van der Putten H, Mosbacher J, Brauner-Osborne H, Waldmeier P, Bettler B. Specific gammahydroxybutyrate-binding sites but loss of pharmacological effects of gamma-hydroxybutyrate in GABA(B)(1)-deficient mice. Eur. J. Neurosci. 2003; 18:2722-2730. [PubMed: 14656321]

Kilduff TS, Bowersox SS, Kaitin KI, Baker TL, Ciaranello RD, Dement WC. Muscarinic cholinergic receptors and the canine model of narcolepsy. Sleep. 1986; 9:102-106. [PubMed: 3704431]

Kilduff TS, Peyron C. The hypocretin/orexin ligand-receptor system: Implications for sleep and sleep disorders. Trends Neurosci. 2000; 23:359-365. [PubMed: 10906799]

Kim HY, Hong E, Kim JI, Lee W. Solution structure of human orexin-A: regulator of appetite and wakefulness. J. Biochem. Mol. Biol. 2004; 37:565-573. [PubMed: 15479620]

Kisanuki YY, Chemelli RM, Willie JT, Sinton CM, Yanagisawa M. Behavioral and polysomnographic characterization of orexin-1 receptor and orexin-2 receptor double knockout mice. Sleep. 2001; 24:A22.

Knudsen S, Biering-Sorensen B, Kornum BR, Petersen ER, Ibsen JD, Gammeltoft S, Mignot E, Jennum PJ. Early IVIg treatment has no effect on post-H1N1 narcolepsy phenotype or hypocretin deficiency. Neurology. 2012; 79:102-103. [PubMed: 22722630]

Knudsen S, Mikkelsen JD, Bang B, Gammeltoft S, Jennum PJ. Intravenous immunoglobulin treatment and screening for hypocretin neuron-specific autoantibodies in recent onset childhood narcolepsy with cataplexy. Neuropediatrics. 2010; 41:217-222. [PubMed: 21210337]

Koepsell TD, Longstreth WT, Ton TG. Medical exposures in youth and the frequency of narcolepsy with cataplexy: a population-based case-control study in genetically predisposed people. J. Sleep Res. 2010; 19:80-86. [PubMed: 19732319]

Kok SW, Meinders AE, Overeem S, Lammers GJ, Roelfsema F, Frolich M, Pijl H. Reduction of plasma leptin levels and loss of its circadian rhythmicity in hypocretin (orexin)-deficient narcoleptic humans. J. Clin. Endocrinol. Metab. 2002; 87:805-809. [PubMed: 11836325]

Kok SW, Overeem S, Visscher TL, Lammers GJ, Seidell JC, Pijl H, Meinders AE. Hypocretin deficiency in narcoleptic humans is associated with abdominal obesity. Obes. Res. 2003; 11:1147-1154. [PubMed: 12972686]

Kornum BR, Faraco J, Mignot E. Narcolepsy with hypocretin/orexin deficiency, infections and autoimmunity of the brain. Curr. Opin. Neurobiol. 2011a; 21:897-903. [PubMed: 21963829]

Kornum BR, Kawashima M, Faraco J, Lin L, Rico TJ, Hesselson S, Axtell RC, Kuipers H, Weiner K, Hamacher A, Kassack MU, Han F, Knudsen S, Li J, Dong X, Winkelmann J, Plazzi G, Nevsimalova S, Hong SC, Honda Y, Honda M, Hogl B, Ton TG, Montplaisir J, Bourgin P, Kemlink D, Huang YS, Warby S, Einen M, Eshragh JL, Miyagawa T, Desautels A, Ruppert E, Hesla PE, Poli F, Pizza F, Frauscher B, Jeong JH, Lee SP, Strohl KP, Longstreth WT Jr. Kvale M, Dobrovolna M, Ohayon MM, Nepom GT, Wichmann HE, Rouleau GA, Gieger C, Levinson DF, Gejman PV, Meitinger T, Peppard P, Young T, Jennum P, Steinman L, Tokunaga K, Kwok PY, Risch N, Hallmayer J, Mignot E. Common variants in P2RY11 are associated with narcolepsy. Nat. Genet. 2011b; 43:66-71. [PubMed: 21170044]

Kornum BR, Pizza F, Knudsen S, Plazzi G, Jennum P, Mignot E. Cerebrospinal fluid cytokine levels in type 1 narcolepsy patients very close to onset. Brain Behav. Immun. 2015; 49:54-58. [PubMed: 25771509]

Krenzer M, Anaclet C, Vetrivelan R, Wang N, Vong L, Lowell BB, Fuller PM, Lu J. Brainstem and spinal cord circuitry regulating REM sleep and muscle atonia. PLoS One. 2011; 6:e24998. [PubMed: 22043278]

Kushida CA, Baker TL, Dement WC. Electroencephalographic correlates of cataplectic attacks in narcoleptic canines. Electroencephalogr. Clin. Neurophysiol. 1985; 61:61-70. [PubMed: 2408864] 
Lammers GJ, Pij1 H, Iestra J, Langius JA, Buunk G, Meinders AE. Spontaneous food choice in narcolepsy. Sleep. 1996; 19:75-76. [PubMed: 8650468]

Langdon N, Shindler J, Parkes JD, Bandak S. Fluoxetine in the treatment of cataplexy. Sleep. 1986; 9:371-373. [PubMed: 3509809]

Langford J, Gross WL. Psychosis in the context of sodium oxybate therapy. J. Clin. Sleep Med. 2011; 7:665-666. [PubMed: 22171207]

Lavie P, Peled R. Narcolepsy is a rare disease in Israel. Sleep. 1987; 10:608-609. [PubMed: 3432862]

Lee JH, Bang E, Chae KJ, Kim JY, Lee DW, Lee W. Solution structure of a new hypothalamic neuropeptide, human hypocretin-2/orexin-B. Eur. J. Biochem. 1999; 266:831-839. [PubMed: 10583376]

Legrand. Narcolepsy. Lancet. 1888:131.

Leonard BE, McCartan D, White J, King DJ. Methylphenidate: a review of its neuropharmacological, neuropsychological and adverse clinical effects. Hum. Psychopharmacol. 2004; 19:151-180. [PubMed: 15079851]

Leviel V. Dopamine release mediated by the dopamine transporter, facts and consequences. J. Neurochem. 2011; 118:475-489. [PubMed: 21644994]

Li R, Mignot E, Faraco J, Kadotani H, Cantanese J, Zhao B, Lin X, Hinton L, Ostrander EA, Patterson DF, de Jong PJ. Construction and characterization of an eightfold redundant dog genomic bacterial artificial chromosome library. Genomics. 1999; 58:9-17. [PubMed: 10331940]

Liblau RS, Vassalli A, Seifinejad A, Tafti M. Hypocretin (orexin) biology and the pathophysiology of narcolepsy with cataplexy. Lancet Neurol. 2015; 14:318-328. [PubMed: 25728441]

Lin L, Faraco J, Li R, Kadotani H, Rogers W, Lin X, Qiu X, de Jong PJ, Nishino S, Mignot E. The sleep disorder canine narcolepsy is caused by a mutation in the hypocretin (orexin) receptor 2 gene. Cell. 1999; 98:365-376. [PubMed: 10458611]

Lipinski CA, Lombardo F, Dominy BW, Feeney PJ. Experimental and computational approaches to estimate solubility and permeability in drug discovery and development settings. Adv. Drug Deliv. Rev. 2001; 46:3-26. [PubMed: 11259830]

Liu M, Blanco-Centurion C, Konadhode R, Begum S, Pelluru D, Gerashchenko D, Sakurai T, Yanagisawa M, van den Pol AN, Shiromani PJ. Orexin gene transfer into zona incerta neurons suppresses muscle paralysis in narcoleptic mice. J. Neurosci. 2011; 31:6028-6040. [PubMed: 21508228]

Liu M, Thankachan S, Kaur S, Begum S, Blanco-Centurion C, Sakurai T, Yanagisawa M, Neve R, Shiromani PJ. Orexin (hypocretin) gene transfer diminishes narcoleptic sleep behavior in mice. Eur. J. Neurosci. 2008; 28:1382-1393. [PubMed: 18973565]

Löwenfeld L. Über narkolepsie. Münch Med Wochenschr. 1902; 49:1041-1045.

Lu J, Sherman D, Devor M, Saper CB. A putative flip-flop switch for control of REM sleep. Nature. 2006; 441:589-594. [PubMed: 16688184]

Luca G, Haba-Rubio J, Dauvilliers Y, Lammers GJ, Overeem S, Donjacour CE, Mayer G, Javidi S, Iranzo A, Santamaria J, Peraita-Adrados R, Hor H, Kutalik Z, Plazzi G, Poli F, Pizza F, Arnulf I, Lecendreux M, Bassetti C, Mathis J, Heinzer R, Jennum P, Knudsen S, Geisler P, Wierzbicka A, Feketeova E, Pfister C, Khatami R, Baumann C, Tafti M. Clinical, polysomnographic and genome-wide association analyses of narcolepsy with cataplexy: a European Narcolepsy Network study. J. Sleep Res. 2013; 22:482-495. [PubMed: 23496005]

Lucas EA, Foutz AS, Dement WC, Mitler MM. Sleep cycle organization in narcoleptic and normal dogs. Physiol. Behav. 1979; 23:737-743. [PubMed: 228334]

Ludvikova E, Nishino S, Sakai N, Jahn P. Familial narcolepsy in the Lipizzaner horse: a report of three fillies born to the same sire. Vet. Q. 2012; 32:99-102. [PubMed: 22889297]

Lunn DP, Cuddon PA, Shaftoe S, Archer RM. Familial occurrence of narcolepsy in miniature horses. Equine Vet. J. 1993; 25:483-487. [PubMed: 7903939]

Luppi PH, Clement O, Sapin E, Gervasoni D, Peyron C, Leger L, Salvert D, Fort P. The neuronal network responsible for paradoxical sleep and its dysfunctions causing narcolepsy and rapid eye movement (REM) behavior disorder. Sleep Med. Rev. 2011; 15:153-163. [PubMed: 21115377] 
Makela KA, Wigren HK, Zant JC, Sakurai T, Alhonen L, Kostin A, Porkka-Heiskanen T, Herzig KH. Characterization of sleep-wake patterns in a novel transgenic mouse line overexpressing human prepro-orexin/hypocretin. Acta Physiol. (Oxf). 2010; 198:237-249. [PubMed: 20003098]

Mamelak M. Narcolepsy and depression and the neurobiology of gamma-hydroxybutyrate. Prog. Neurobiol. 2009; 89:193-219. [PubMed: 19654034]

Mathis, J., Hess, CW. Vigilance tests in narcolepsy.. In: Bassetti, CL.Billiard, M., Mignot, E., editors. Narcolepsy and Hypersomnia. Informa Healthcare USA; New York, NY: 2007. p. 243-256.

Matsuki K, Grumet FC, Lin X, Gelb M, Guilleminault C, Dement WC, Mignot E. DQ (rather than DR) gene marks susceptibility to narcolepsy. Lancet. 1992; 339:1052.

Mayer G, Meier-Ewert K. Motor dyscontrol in sleep of narcoleptic patients (a lifelong development?). J. Sleep Res. 1993; 2:143-148. [PubMed: 10607086]

McGinty DJ, Harper RM. Dorsal raphe neurons: depression of firing during sleep in cats. Brain Res. 1976; 101:569-575. [PubMed: 1244990]

Meerlo P, Westerveld P, Turek FW, Koehl M. Effects of gamma-hydroxybutyrate (GHB) on vigilance states and EEG in mice. Sleep. 2004; 27:899-904. [PubMed: 15453548]

Mefford IN, Baker TL, Boehme R, Foutz AS, Ciaranello RD, Barchas JD, Dement WC. Narcolepsy: biogenic amine deficits in an animal model. Science. 1983; 220:629-632. [PubMed: 6188216]

Merkle FT, Maroof A, Wataya T, Sasai Y, Studer L, Eggan K, Schier AF. Generation of neuropeptidergic hypothalamic neurons from human pluripotent stem cells. Development. 2015; 142:633-643. [PubMed: 25670790]

Michelson D, Snyder E, Paradis E, Chengan-Liu M, Snavely DB, Hutzelmann J, Walsh JK, Krystal AD, Benca RM, Cohn M, Lines C, Roth T, Herring WJ. Safety and efficacy of suvorexant during 1-year treatment of insomnia with subsequent abrupt treatment discontinuation: a phase 3 randomised, double-blind, placebo-controlled trial. Lancet Neurol. 2014; 13:461-471. [PubMed: 24680372]

Mieda M, Hasegawa E, Kisanuki YY, Sinton CM, Yanagisawa M, Sakurai T. Differential roles of orexin receptor-1 and -2 in the regulation of non-REM and REM sleep. J. Neurosci. 2011; 31:6518-6526. [PubMed: 21525292]

Mieda M, Willie JT, Hara J, Sinton CM, Sakurai T, Yanagisawa M. Orexin peptides prevent cataplexy and improve wakefulness in an orexin neuronablated model of narcolepsy in mice. Proc. Natl. Acad. Sci. U.S.A. 2004; 101:4649-4654. [PubMed: 15070772]

Mignot E. Genetics of narcolepsy and other sleep disorders. Am. J. Hum. Genet. 1997; 60:1289-1302. [PubMed: 9199548]

Mignot E. Genetic and familial aspects of narcolepsy. Neurology. 1998; 50:S16-S22. [PubMed: 9484418]

Mignot E. A hundred years of narcolepsy research. Arch. Ital. Biol. 2001; 139:207-220. [PubMed: 11330202]

Mignot E, Guilleminault C, Bowersox S, Rappaport A, Dement WC. Effect of alpha 1-adrenoceptors blockade with prazosin in canine narcolepsy. Brain Res. 1988a; 444:184-188. [PubMed: 2834022]

Mignot E, Guilleminault C, Bowersox S, Rappaport A, Dement WC. Role of central alpha-1 adrenoceptors in canine narcolepsy. J. Clin. Investig. 1988b; 82:885-894. [PubMed: 2843574]

Mignot E, Hayduk R, Black J, Grumet FC, Guilleminault C. HLA DQB1*0602 is associated with cataplexy in 509 narcoleptic patients. Sleep. 1997; 20:1012-1020. [PubMed: 9456467]

Mignot E, Lammers GJ, Ripley B, Okun M, Nevsimalova S, Overeem S, Vankova J, Black J, Harsh J, Bassetti C, Schrader H, Nishino S. The role of cerebrospinal fluid hypocretin measurement in the diagnosis of narcolepsy and other hypersomnias. Arch. Neurol. 2002; 59:1553-1562. [PubMed: 12374492]

Mignot E, Lin L, Rogers W, Honda Y, Qiu X, Lin X, Okun M, Hohjoh H, Miki T, Hsu S, Leffell M, Grumet F, Fernandez-Vina M, Honda M, Risch N. Complex HLA-DR and -DQ interactions confer risk of narcolepsy-cataplexy in three ethnic groups. Am. J. Hum. Genet. 2001; 68:686699. [PubMed: 11179016] 
Mignot, E., Nishino, S. Perspectives for new treatments: an update.. In: Bassetti, CL.Billiard, M., Mignot, E., editors. Narcolepsy and Hypersomnia. Informa Healthcare USA; New York, NY: 2007. p. 641-654.

Mignot E, Lin X, Arrigoni J, Macaubas C, Olive F, Hallmayer J, Underhill P, Guilleminault C, Dement WC, Grumet FC. a DQB1*0602 and DQA1*0102 (DQ1) are better markers than DR2 for narcolepsy in Caucasian and black Americans. Sleep. 1994a; 17:S60-S67. [PubMed: 7701202]

Mignot E, Nishino S, Guilleminault C, Dement WC. Modafinil binds to the dopamine uptake carrier site with low affinity. Sleep. 1994b; 17:436-437. [PubMed: 7991954]

Mignot E, Renaud A, Nishino S, Arrigoni J, Guilleminault C, Dement WC. Canine cataplexy is preferentially controlled by adrenergic mechanisms: evidence using monoamine selective uptake inhibitors and release enhancers. Psychopharmacology (Berl). 1993; 113:76-82. [PubMed: 7862832]

Mignot EJ. A practical guide to the therapy of narcolepsy and hypersomnia syndromes. Neurotherapeutics. 2012; 9:739-752. [PubMed: 23065655]

Mignot EJ. History of narcolepsy at Stanford University. Immunol. Res. 2014; 58:315-339. [PubMed: 24825774]

Mileykovskiy BY, Kiyashchenko LI, Siegel JM. Behavioral correlates of activity in identified hypocretin/orexin neurons. Neuron. 2005; 46:787-798. [PubMed: 15924864]

Miller JD, Faull KF, Bowersox SS, Dement WC. CNS monoamines and their metabolites in canine narcolepsy: a replication study. Brain Res. 1990; 509:169-171. [PubMed: 1689603]

Miro O, Nogue S, Espinosa G, To-Figueras J, Sanchez M. Trends in illicit drug emergencies: the emerging role of gamma-hydroxybutyrate. J. Toxicol. Clin. Toxicol. 2002; 40:129-135. [PubMed: 12126184]

Mitler MM, Dement WC. Sleep studies on canine narcolepsy: pattern and cycle comparisons between affected and normal dogs. Electroencephalogr. Clin. Neurophysiol. 1977; 43:691-699. [PubMed: 72649]

Mitler MM, Soave O, Dement WC. Narcolepsy in seven dogs. J. Am. Vet. Med. Assoc. 1976; 168:1036-1038. [PubMed: 945254]

Mitler MM, Van den Hoed J, Carskadon MA, Richardson G, Park R, Guilleminault C, Dement WC. REM sleep episodes during the Multiple Sleep Latency Test in narcoleptic patients. Electroencephalogr. Clin. Neurophysiol. 1979; 46:479-481. [PubMed: 85544]

Mochizuki T, Arrigoni E, Marcus JN, Clark EL, Yamamoto M, Honer M, Borroni E, Lowell BB, Elmquist JK, Scammell TE. Orexin receptor 2 expression in the posterior hypothalamus rescues sleepiness in narcoleptic mice. Proc. Natl. Acad. Sci. U.S.A. 2011; 108:4471-4476. [PubMed: 21368172]

Mochizuki T, Crocker A, McCormack S, Yanagisawa M, Sakurai T, Scammell TE. Behavioral state instability in orexin knock-out mice. J. Neurosci. 2004; 24:6291-6300. [PubMed: 15254084]

Mochizuki T, Klerman EB, Sakurai T, Scammell TE. Elevated body temperature during sleep in orexin knockout mice. Am. J. Physiol. Regul. Integr. Comp. Physiol. 2006; 291:R533-R540. [PubMed: 16556901]

Montplaisir J, Petit D, Quinn MJ, Ouakki M, Deceuninck G, Desautels A, Mignot E, De Wals P. Risk of narcolepsy associated with inactivated adjuvanted (AS03) A/H1N1 (2009) pandemic influenza vaccine in Quebec. PLoS One. 2014; 9:e108489. [PubMed: 25264897]

Morawska M, Buchi M, Fendt M. Narcoleptic episodes in orexin-deficient mice are increased by both attractive and aversive odors. Behav. Brain Res. 2011; 222:397-400. [PubMed: 21510981]

Mori T, Ito S, Kuwaki T, Yanagisawa M, Sakurai T, Sawaguchi T. Monoaminergic neuronal changes in orexin deficient mice. Neuropharmacology. 2010; 58:826-832. [PubMed: 19703479]

Mosko SS, Holowach JB, Sassin JF. The 24-hour rhythm of core temperature in narcolepsy. Sleep. 1983; 6:137-146. [PubMed: 6878983]

Motoyama M, Kilduff TS, Lee BS, Dement WC, McDevitt HO. Restriction fragment length polymorphism in canine narcolepsy. Immunogenetics. 1989; 29:124-126. [PubMed: 2563354]

Muraki Y, Yamanaka A, Tsujino N, Kilduff TS, Goto K, Sakurai T. Serotonergic regulation of the orexin/hypocretin neurons through the 5-HT1A receptor. J. Neurosci. 2004; 24:7159-7166. [PubMed: 15306649] 
Nagahara T, Saitoh T, Kutsumura N, Irukayama-Tomobe Y, Ogawa Y, Kuroda D, Gouda H, Kumagai H, Fujii H, Yanagisawa M, Nagase H. Design and synthesis of non-peptide selective orexin receptor 2 agonists. J. Med. Chem. 2015; 58:7931-7937. [PubMed: 26267383]

Nakamura M, Nishida S, Hayashida K, Ueki Y, Dauvilliers Y, Inoue Y. Differences in brain morphological findings between narcolepsy with and without cataplexy. PLoS One. 2013; 8:e81059. [PubMed: 24312261]

Nevsimalova S. Narcolepsy in childhood. Sleep Med. Rev. 2009; 13:169-180. [PubMed: 19153053]

Niewoehner J, Bohrmann B, Collin L, Urich E, Sade H, Maier P, Rueger P, Stracke JO, Lau W, Tissot AC, Loetscher H, Ghosh A, Freskgard PO. Increased brain penetration and potency of a therapeutic antibody using a monovalent molecular shuttle. Neuron. 2014; 81:49-60. [PubMed: 24411731]

Nishino S. Clinical and neurobiological aspects of narcolepsy. Sleep Med. 2007; 8:373-399. [PubMed: 17470414]

Nishino S, Arrigoni J, Valtier D, Miller JD, Guilleminault C, Dement WC, Mignot E. Dopamine D2 mechanisms in canine narcolepsy. J. Neurosci. 1991; 11:2666-2671. [PubMed: 1831837]

Nishino S, Fruhstorfer B, Arrigoni J, Guilleminault C, Dement WC, Mignot E. Further characterization of the alpha-1 receptor subtype involved in the control of cataplexy in canine narcolepsy. J. Pharmacol. Exp. Ther. 1993; 264:1079-1084. [PubMed: 8095546]

Nishino S, Haak L, Shepherd H, Guilleminault C, Sakai T, Dement WC, Mignot E. Effects of central alpha-2 adrenergic compounds on canine narcolepsy, a disorder of rapid eye movement sleep. J. Pharmacol. Exp. Ther. 1990; 253:1145-1152. [PubMed: 1972749]

Nishino S, Mignot E. Pharmacological aspects of human and canine narcolepsy. Prog. Neurobiol. 1997; 52:27-78. [PubMed: 9185233]

Nishino, S., Mignot, E. Wake-promoting medications: basic mechanisms and pharmacology.. In: Kryger, MH.Roth, T., Dement, WC., editors. Principles and Practice of Sleep Medicine. Elsevier Saunders; St. Louis, Missouri: 2011. p. 510-526.

Nishino S, Mignot E, Fruhstorfer B, Dement WC, Hayaishi O. Prostaglandin E2 and its methyl ester reduce cataplexy in canine narcolepsy. Proc. Natl. Acad. Sci. U.S.A. 1989; 86:2483-2487. [PubMed: 2928344]

Nishino S, Ripley B, Overeem S, Lammers GJ, Mignot E. Hypocretin (orexin) deficiency in human narcolepsy. Lancet. 2000; 355:39-40. [PubMed: 10615891]

Nishino S, Ripley B, Overeem S, Nevsimalova S, Lammers GJ, Vankova J, Okun M, Rogers W, Brooks S, Mignot E. Low cerebrospinal fluid hypocretin (Orexin) and altered energy homeostasis in human narcolepsy. Ann. Neurol. 2001; 50:381-388. [PubMed: 11558795]

Nishino S, Sakurai E, Nevsimalova S, Yoshida Y, Watanabe T, Yanai K, Mignot E. Decreased CSF histamine in narcolepsy with and without low CSF hypocretin-1 in comparison to healthy controls. Sleep. 2009; 32:175-180. [PubMed: 19238804]

Nishino S, Tafti M, Reid MS, Shelton J, Siegel JM, Dement WC, Mignot E. Muscle atonia is triggered by cholinergic stimulation of the basal fore-brain: implication for the pathophysiology of canine narcolepsy. J. Neurosci. 1995; 15:4806-4814. [PubMed: 7623112]

Nohynek H, Jokinen J, Partinen M, Vaarala O, Kirjavainen T, Sundman J, Himanen SL, Hublin C, Julkunen I, Olsen P, Saarenpaa-Heikkila O, Kilpi T. AS03 adjuvanted AH1N1 vaccine associated with an abrupt increase in the incidence of childhood narcolepsy in Finland. PLoS One. 2012; 7:e33536. [PubMed: 22470453]

O'Flanagan D, Barret AS, Foley M, Cotter S, Bonner C, Crowe C, Lynch B, Sweeney B, Johnson H, McCoy B, Purcell E. Investigation of an association between onset of narcolepsy and vaccination with pandemic influenza vaccine Ireland April 2009-December 2010. EuroSurveillance. 2014; 19:15-25. [PubMed: 24821121]

Ohayon MM. Narcolepsy is complicated by high medical and psychiatric comorbidities: a comparison with the general population. Sleep Med. 2013; 14:488-492. [PubMed: 23643648]

Ohayon MM, Black J, Lai C, Eller M, Guinta D, Bhattacharyya A. Increased mortality in narcolepsy. Sleep. 2014; 37:439-444. [PubMed: 24587565] 
Ohayon MM, Priest RG, Zulley J, Smirne S, Paiva T. Prevalence of narcolepsy symptomatology and diagnosis in the European general population. Neurology. 2002; 58:1826-1833. [PubMed: 12084885]

Oishi Y, Williams RH, Agostinelli L, Arrigoni E, Fuller PM, Mochizuki T, Saper CB, Scammell TE. Role of the medial prefrontal cortex in cataplexy. J. Neurosci. 2013; 33:9743-9751. [PubMed: 23739971]

Ollila HM, Ravel JM, Han F, Faraco J, Lin L, Zheng X, Plazzi G, Dauvilliers Y, Pizza F, Hong SC, Jennum P, Knudsen S, Kornum BR, Dong XS, Yan H, Hong H, Coquillard C, Mahlios J, Jolanki O, Einen M, Arnulf I, Hogl B, Frauscher B, Crowe C, Partinen M, Huang YS, Bourgin P, Vaarala O, Desautels A, Montplaisir J, Mack SJ, Mindrinos M, Fernandez-Vina M, Mignot E. HLADPB1 and HLA class I confer risk of and protection from narcolepsy. Am. J. Hum. Genet. 2015; 96:136-146. [PubMed: 25574827]

Ortega JE, Katner J, Davis R, Wade M, Nisenbaum L, Nomikos GG, Svensson KA, Perry KW. Modulation of neurotransmitter release in orexin/hypocretin- 2 receptor knockout mice: a microdialysis study. J. Neurosci. Res. 2012; 90:588-596. [PubMed: 22038504]

Overeem S, Verschuuren JJ, Fronczek R, Schreurs L, den Hertog H, Hegeman-Kleinn IM, van Duinen SG, Unmehopa UA, Swaab DF, Lammers GJ. Immunohistochemical screening for autoantibodies against lateral hypothalamic neurons in human narcolepsy. J. Neuroimmunol. 2006; 174:187191. [PubMed: 16563524]

Pacey LK, Tharmalingam S, Hampson DR. Subchronic administration and combination metabotropic glutamate and GABAB receptor drug therapy in fragile X syndrome. J. Pharmacol. Exp. Ther. 2011; 338:897-905. [PubMed: 21636656]

Palaia V, Poli F, Pizza F, Antelmi E, Franceschini C, Moghadam KK, Provini F, Pagotto U, Montagna P, Schenck CH, Mignot E, Plazzi G. Narcolepsy with cataplexy associated with nocturnal compulsive behaviors: a case-control study. Sleep. 2011; 34:1365-1371. [PubMed: 21966068]

Parkes JD, Chen SY, Clift SJ, Dahlitz MJ, Dunn G. The clinical diagnosis of the narcoleptic syndrome. J. Sleep Res. 1998; 7:41-52. [PubMed: 9613427]

Partinen M, Saarenpaa-Heikkila O, Ilveskoski I, Hublin C, Linna M, Olsen P, Nokelainen P, Alen R, Wallden T, Espo M, Rusanen H, Olme J, Satila H, Arikka H, Kaipainen P, Julkunen I, Kirjavainen T. Increased incidence and clinical picture of childhood narcolepsy following the 2009 H1N1 pandemic vaccination campaign in Finland. PLoS One. 2012; 7:e33723. [PubMed: 22470463]

Paterson NE, Fedolak A, Olivier B, Hanania T, Ghavami A, Caldarone B. Psychostimulant-like discriminative stimulus and locomotor sensitization properties of the wake-promoting agent modafinil in rodents. Pharmacol. Biochem. Behav. 2010; 95:449-456. [PubMed: 20346966]

Peever J. Control of motoneuron function and muscle tone during REM sleep REM sleep behavior disorder and cataplexy/narcolepsy. Arch. Ital. Biol. 2011; 149:454-466. [PubMed: 22205591]

Peever JH, Lai YY, Siegel JM. Excitatory effects of hypocretin-1 (orexin-A) in the trigeminal motor nucleus are reversed by NMDA antagonism. J. Neurophysiol. 2003; 89:2591-2600. [PubMed: 12611960]

Pelin Z, Guilleminault C, Risch N, Grumet FC, Mignot E. HLA-DQB1*0602 homozygosity increases relative risk for narcolepsy but not disease severity in two ethnic groups. US Modafinil in Narcolepsy Multicenter Study Group. Tissue Antigens. 1998; 51:96-100. [PubMed: 9459509]

Peyron C, Faraco J, Rogers W, Ripley B, Overeem S, Charnay Y, Nevsimalova S, Aldrich M, Reynolds D, Albin R, Li R, Hungs M, Pedrazzoli M, Padigaru M, Kucherlapati M, Fan J, Maki R, Lammers GJ, Bouras C, Kucherlapati R, Nishino S, Mignot E. A mutation in a case of early onset narcolepsy and a generalized absence of hypocretin peptides in human narcoleptic brains. Nat. Med. 2000; 6:991-997. [PubMed: 10973318]

Peyron C, Tighe DK, Lee BS, de Lecea L, Heller HC, Sutcliffe JG, Kilduff TS. Distribution of immunoreactive neurons and fibers for a hypothalamic neuropeptide precursor related to secretin. Soc. Neurosci. Abs. 1997; 23:2032.

Peyron C, Tighe DK, van den Pol AN, de Lecea L, Heller HC, Sutcliffe JG, Kilduff TS. Neurons containing hypocretin (orexin) project to multiple neuronal systems. J. Neurosci. 1998; 18:999610015. [PubMed: 9822755] 
Plazzi G, Ferri R, Antelmi E, Bayard S, Franceschini C, Cosentino FI, Abril B, Spruyt K, Provini F, Montagna P, Dauvilliers Y. Restless legs syndrome is frequent in narcolepsy with cataplexy patients. Sleep. 2010; 33:689-694. [PubMed: 20469811]

Plazzi G, Moghadam KK, Maggi LS, Donadio V, Vetrugno R, Liguori R, Zoccoli G, Poli F, Pizza F, Pagotto U, Ferri R. Autonomic disturbances in narcolepsy. Sleep Med. Rev. 2011; 15:187-196. [PubMed: 20634114]

Poli F, Plazzi G, Di Dalmazi G, Ribichini D, Vicennati V, Pizza F, Mignot E, Montagna P, Pasquali R, Pagotto U. Body mass index-independent metabolic alterations in narcolepsy with cataplexy. Sleep. 2009; 32:1491-1497. [PubMed: 19928388]

Pollak CP, Wagner DR. Core body temperature in narcoleptic and normal subjects living in temporal isolation. Pharmacol. Biochem. Behav. 1994; 47:65-71. [PubMed: 8115430]

Pollock MS, Mistlberger RE. Rapid eye movement sleep induction by microinjection of the GABA-A antagonist bicuculline into the dorsal subcoeruleus area of the rat. Brain Res. 2003; 962:68-77. [PubMed: 12543457]

Prinzmetal M, Bloomberg W. The use of benzedrine for the treatment of narcolepsy. J. Am. Med. Assoc. 1935; 105:2051-2054.

Rechtschaffen A, Wolpert EA, Dement WC, Mitchell SA, Fisher C. Nocturnal sleep of narcoleptics. Electroencephalogr. Clin. Neurophysiol. 1963; 15:599-609. [PubMed: 14161512]

Reid MS, Tafti M, Nishino S, Sampathkumaran R, Siegel JM, Mignot E. Local administration of dopaminergic drugs into the ventral tegmental area modulates cataplexy in the narcoleptic canine. Brain Res. 1996; 733:83-100. [PubMed: 8891251]

Reid MS, Tafti M, Nishino S, Siegel JM, Dement WC, Mignot E. Cholinergic regulation of cataplexy in canine narcolepsy in the pontine reticular formation is mediated by M2 muscarinic receptors. Sleep. 1994; 17:424-435. [PubMed: 7991953]

Richardson GS, Carskadon MA, Flagg W, Van den Hoed J, Dement WC, Mitler MM. Excessive daytime sleepiness in man: multiple sleep latency measurement in narcoleptic and control subjects. Electroencephalogr. Clin. Neurophysiol. 1978; 45:621-627. [PubMed: 81764]

Ripley B, Fujiki N, Okura M, Mignot E, Nishino S. Hypocretin levels in sporadic and familial canine narcolepsy. Neurobiol. Dis. 2001; 8:525-534. [PubMed: 11442359]

Ristanovic RK, Liang H, Hornfeldt CS, Lai C. Exacerbation of cataplexy following gradual withdrawal of antidepressants: manifestation of probable protracted rebound cataplexy. Sleep Med. 2009; 10:416-421. [PubMed: 18753005]

Roth T, Dauvilliers Y, Mignot E, Montplaisir J, Paul J, Swick T, Zee P. Disrupted nighttime sleep in narcolepsy. J. Clin. Sleep Med. 2013; 9:955-965. [PubMed: 23997709]

Sachs C, Kaijser L. Autonomic regulation of cardiopulmonary functions in sleep apnea syndrome and narcolepsy. Sleep. 1982; 5:227-238. [PubMed: 6813932]

Sakurai T. The role of orexin in motivated behaviours. Nat. Rev. Neurosci. 2014; 15:719-731. [PubMed: 25301357]

Sakurai T, Amemiya A, Ishii M, Matsuzaki I, Chemelli RM, Tanaka H, Williams SC, Richardson JA, Kozlowski GP, Wilson S, Arch JR, Buckingham RE, Haynes AC, Carr SA, Annan RS, McNulty DE, Liu WS, Terrett JA, Elshourbagy NA, Bergsma DJ, Yanagisawa M. Orexins and orexin receptors: a family of hypothalamic neuropeptides and $\mathrm{G}$ protein-coupled receptors that regulate feeding behavior. Cell. 1998; 92:573-585. [PubMed: 9491897]

Saper CB, Chou TC, Scammell TE. The sleep switch: hypothalamic control of sleep and wakefulness. Trends Neurosci. 2001; 24:726-731. [PubMed: 11718878]

Saper CB, Fuller PM, Pedersen NP, Lu J, Scammell TE. Sleep state switching. Neuron. 2010; 68:1023-1042. [PubMed: 21172606]

Scammell TE, Willie JT, Guilleminault C, Siegel JM. A consensus definition of cataplexy in mouse models of narcolepsy. Sleep. 2009; 32:111-116. [PubMed: 19189786]

Schenck CH, Bassetti CL, Arnulf I, Mignot E. English translations of the first clinical reports on narcolepsy and cataplexy by Westphal and Gelineau in the late 19th century, with commentary. J. Clin. Sleep Med. 2007; 3:301-311. [PubMed: 17561602]

Prog Neurobiol. Author manuscript; available in PMC 2018 May 01. 
Schuld A, Beitinger PA, Dalal M, Geller F, Wetter TC, Albert ED, Hebebrand J, Pollmacher T. Increased body mass index (BMI) in male narcoleptic patients, but not in HLA-DR2-positive healthy male volunteers. Sleep Med. 2002; 3:335-339. [PubMed: 14592196]

Schuld A, Blum WF, Uhr M, Haack M, Kraus T, Holsboer F, Pollmacher T. Reduced leptin levels in human narcolepsy. Neuroendocrinology. 2000; 72:195-198. [PubMed: 11070422]

Seeman P, Guan HC, Hirbec H. Dopamine D2High receptors stimulated by phencyclidines, lysergic acid diethylamide, salvinorin A, and modafinil. Synapse. 2009; 63:698-704. [PubMed: 19391150]

Sellayah D, Bharaj P, Sikder D. Orexin is required for brown adipose tissue development, differentiation, and function. Cell Metab. 2011; 14:478-490. [PubMed: 21982708]

Shelton J, Nishino S, Vaught J, Dement WC, Mignot E. Comparative effects of modafinil and amphetamine on daytime sleepiness and cataplexy of narcoleptic dogs. Sleep. 1995; 18:817-826. [PubMed: 8746387]

Shuman T, Cai DJ, Sage JR, Anagnostaras SG. Interactions between modafinil and cocaine during the induction of conditioned place preference and locomotor sensitization in mice: implications for addiction. Behav. Brain Res. 2012; 235:105-112. [PubMed: 22963989]

Siegel JM, Nienhuis R, Fahringer HM, Paul R, Shiromani P, Dement WC, Mignot E, Chiu C. Neuronal activity in narcolepsy: identification of cataplexy-related cells in the medial medulla. Science. 1991; 252:1315-1318. [PubMed: 1925546]

Silber MH, Krahn LE, Olson EJ, Pankratz VS. The epidemiology of narcolepsy in Olmsted County Minnesota: a population-based study. Sleep. 2002; 25:197-202. [PubMed: 11902429]

Silverman JL, Pride MC, Hayes JE, Puhger KR, Butler-Struben HM, Baker S, Crawley JN. GABA receptor agonist R-baclofen reverses social deficits and reduces repetitive behavior in two mouse models of autism. Neuropsychopharmacology. 2015; 40(9):2228-2239. [PubMed: 25754761]

Sorensen GL, Knudsen S, Petersen ER, Kempfner J, Gammeltoft S, Sorensen HB, Jennum P. Attenuated heart rate response is associated with hypocretin deficiency in patients with narcolepsy. Sleep. 2013; 36:91-98. [PubMed: 23288975]

Strain GM, Olcott BM, Archer RM, McClintock BK. Narcolepsy in a Brahman bull. J. Am. Vet. Med. Assoc. 1984; 185:538-541. [PubMed: 6541218]

Study Group U.S.X.M. A randomized, double blind, placebo-controlled multicenter trial comparing the effects of three doses of orally administered sodium oxybate with placebo for the treatment of narcolepsy. Sleep. 2002; 25:42-49. [PubMed: 11833860]

Study Group, U.S.M.X. A 12-month, open-label, multicenter extension trial of orally administered sodium oxybate for the treatment of narcolepsy. Sleep. 2003a; 26:31-35. [PubMed: 12627729]

Study Group U.S.X.M. The abrupt cessation of therapeutically administered sodium oxybate (GHB) does not cause withdrawal symptoms. J. Toxicol. Clin. Toxicol. 2003b; 41:131-135. [PubMed: 12733850]

Study Group U.S.X.M. Sodium oxybate demonstrates long-term efficacy for the treatment of cataplexy in patients with narcolepsy. Sleep Med. 2004; 5:119-123. [PubMed: 15033130]

Study Group X.I. Further evidence supporting the use of sodium oxybate for the treatment of cataplexy: a double-blind, placebo-controlled study in 228 patients. Sleep Med. 2005; 6:415-421. [PubMed: 16099718]

Sutcliffe JG, Gautvik KM, Kilduff TS, Horn T, Foye PE, Danielson PE, Frankel WN, Bloom FE, de Lecea L. Two novel hypothalamic peptides related to secretin derived from a single neuropeptide precursor. Soc. Neurosci. Abs. 1997; 23:2032.

Sweeney CR, Hendricks JC, Beech J, Morrison AR. Narcolepsy in a horse. J. Am. Vet. Med. Assoc. 1983; 183:126-128. [PubMed: 6683719]

Tabuchi S, Tsunematsu T, Black SW, Tominaga M, Maruyama M, Takagi K, Minokoshi Y, Sakurai T, Kilduff TS, Yamanaka A. Conditional ablation of orexin/hypocretin neurons: a new mouse model for the study of narcolepsy and orexin system function. J. Neurosci. 2014; 34:6495-6509. [PubMed: 24806676]

Tafti M, Hor H, Dauvilliers Y, Lammers GJ, Overeem S, Mayer G, Javidi S, Iranzo A, Santamaria J, Peraita-Adrados R, Vicario JL, Arnulf I, Plazzi G, Bayard S, Poli F, Pizza F, Geisler P, Wierzbicka A, Bassetti CL, Mathis J, Lecendreux M, Donjacour CE, van der Heide A, Heinzer 
R, Haba-Rubio J, Feketeova E, Hogl B, Frauscher B, Beneto A, Khatami R, Canellas F, Pfister C, Scholz S, Billiard M, Baumann CR, Ercilla G, Verduijn W, Claas FH, Dubois V, Nowak J, Eberhard HP, Pradervand S, Hor CN, Testi M, Tiercy JM, Kutalik Z. DQB1 locus alone explains most of the risk and protection in narcolepsy with cataplexy in Europe. Sleep. 2014; 37:19-25. [PubMed: 24381371]

Tafti M, Rondouin G, Besset A, Billiard M. Sleep deprivation in narcoleptic subjects: effect on sleep stages and EEG power density. Electroencephalogr. Clin. Neurophysiol. 1992; 83:339-349. [PubMed: 1281079]

Tanaka KF, Matsui K, Sasaki T, Sano H, Sugio S, Fan K, Hen R, Nakai J, Yanagawa Y, Hasuwa H, Okabe M, Deisseroth K, Ikenaka K, Yamanaka A. Expanding the repertoire of optogenetically targeted cells with an enhanced gene expression system. Cell Rep. 2012; 2:397-406. [PubMed: 22854021]

Tanaka S, Honda Y, Inoue Y, Honda M. Detection of autoantibodies against hypocretin, hcrtrl, and hcrtr2 in narcolepsy: anti-Hcrt system antibody in narcolepsy. Sleep. 2006; 29:633-638. [PubMed: 16774153]

Tashiro T, Kanbayashi T, Iijima S, Hishikawa Y. An epidemiological study on prevalence of narcolpsy in Japanese. J. Sleep Res. 1992; 1:228.

Thannickal T, Moore R, Nienhuis Y, Ramanathan R, Gulyani L, Aldrich S, Cornford M, Siegel MJM. Reduced number of hypocretin neurons in human narcolepsy. Neuron. 2000; 27:469-474. [PubMed: 11055430]

Thannickal TC, Nienhuis R, Siegel JM. Localized loss of hypocretin (orexin) cells in narcolepsy without cataplexy. Sleep. 2009; 32:993-998. [PubMed: 19725250]

Thorpy MJ, Dauvilliers Y. Clinical and practical considerations in the pharmacologic management of narcolepsy. Sleep Med. 2015; 16:9-18. [PubMed: 25458251]

Thorpy MJ, Krieger AC. Delayed diagnosis of narcolepsy: characterization and impact. Sleep Med. 2014; 15:502-507. [PubMed: 24780133]

Tsunematsu T, Kilduff TS, Boyden ES, Takahashi S, Tominaga M, Yamanaka A. Acute optogenetic silencing of orexin/hypocretin neurons induces slow-wave sleep in mice. J. Neurosci. 2011; 31:10529-10539. [PubMed: 21775598]

Tsunematsu T, Tabuchi S, Tanaka KF, Boyden ES, Tominaga M, Yamanaka A. Long-lasting silencing of orexin/hypocretin neurons using archaerhodopsin induces slow-wave sleep in mice. Behav. Brain Res. 2013; 255:64-74. [PubMed: 23707248]

Tupone D, Madden CJ, Cano G, Morrison SF. An orexinergic projection from perifornical hypothalamus to raphe pallidus increases rat brown adipose tissue thermogenesis. J. Neurosci. 2011; 31:15944-15955. [PubMed: 22049437]

Valko PO, Gavrilov YV, Yamamoto M, Reddy H, Haybaeck J, Mignot E, Baumann CR, Scammell TE. Increase of histaminergic tuberomammillary neurons in narcolepsy. Ann. Neurol. 2013; 74:794804. [PubMed: 24006291]

Valko PO, Khatami R, Baumann CR, Bassetti CL. No persistent effect of intravenous immunoglobulins in patients with narcolepsy with cataplexy. J. Neurol. 2008; 255:1900-1903. [PubMed: 18825431]

van Amsterdam JG, Brunt TM, McMaster MT, Niesink RJ. Possible long-term effects of gammahydroxybutyric acid (GHB) due to neurotoxicity and overdose. Neurosci. Biobehav. Rev. 2012; 36:1217-1227. [PubMed: 22342779]

Van Cauter E, Plat L, Scharf MB, Leproult R, Cespedes S, L'Hermite-Baleriaux M, Copinschi G. Simultaneous stimulation of slow-wave sleep and growth hormone secretion by gammahydroxybutyrate in normal young Men. J. Clin. Investig. 1997; 100:745-753. [PubMed: 9239423]

van den Pol AN. Hypothalamic hypocretin (orexin): robust innervation of the spinal cord. J. Neurosci. 1999; 19:3171-3182. [PubMed: 10191330]

Vassalli A, Dellepiane JM, Emmenegger Y, Jimenez S, Vandi S, Plazzi G, Franken P, Tafti M. Electroencephalogram paroxysmal theta characterizes cataplexy in mice and children. Brain. 2013; 136:1592-1608. [PubMed: 23616586] 
Vetrivelan R, Saper CB, Fuller PM. Armodafinil-induced wakefulness in animals with ventrolateral preoptic lesions. Nat. Sci. Sleep. 2014; 6:57-63. [PubMed: 24833927]

Vienne J, Bettler B, Franken P, Tafti M. Differential effects of GABAB receptor subtypes \{gamma\}hydroxybutyric acid, and baclofen on EEG activity and sleep regulation. J. Neurosci. 2010; 30:14194-14204. [PubMed: 20962240]

Vienne J, Lecciso G, Constantinescu I, Schwartz S, Franken P, Heinzer R, Tafti M. Differential effects of sodium oxybate and baclofen on EEG, sleep, neurobehavioral performance, and memory. Sleep. 2012; 35:1071-1083. [PubMed: 22851803]

Volkow ND, Fowler JS, Wang GJ, Baler R, Telang F. Imaging dopamine's role in drug abuse and addiction. Neuropharmacology. 2009; 56(Suppl 1):S3-S8.

Walsh JK, Hall-Porter JM, Griffin KS, Dodson ER, Forst EH, Curry DT, Eisenstein RD, Schweitzer PK. Enhancing slow wave sleep with sodium oxybate reduces the behavioral and physiological impact of sleep loss. Sleep. 2010; 33:1217-1225. [PubMed: 20857869]

Wang J, Greenberg H. Status cataplecticus precipitated by abrupt withdrawal of venlafaxine. J. Clin. Sleep Med. 2013; 9:715-716. [PubMed: 23853567]

Wang L, Meece K, Williams DJ, Lo KA, Zimmer M, Heinrich G, Martin Carli J, Leduc CA, Sun L, Zeltser LM, Freeby M, Goland R, Tsang SH, Wardlaw SL, Egli D, Leibel RL. Differentiation of hypothalamic-like neurons from human pluripotent stem cells. J. Clin. Investig. 2015; 125:796808. [PubMed: 25555215]

Weinhold SL, Seeck-Hirschner M, Nowak A, Hallschmid M, Goder R, Baier PC. The effect of intranasal orexin-A (hypocretin-1) on sleep, wakefulness and attention in narcolepsy with cataplexy. Behav. Brain Res. 2014; 262:8-13. [PubMed: 24406723]

Westphal C. Eigenhümliche mit Einschläfen verbundene Anfälle. Arch. Psychiatry. 1877; 7:631-635.

Willie JT, Chemelli RM, Sinton CM, Tokita S, Williams SC, Kisanuki YY, Marcus JN, Lee C, Elmquist JK, Kohlmeier KA, Leonard CS, Richardson JA, Hammer RE, Yanagisawa M. Distinct narcolepsy syndromes in Orexin receptor-2 and Orexin null mice: molecular genetic dissection of Non-REM and REM sleep regulatory processes. Neuron. 2003; 38:715-730. [PubMed: 12797957]

Willie JT, Renthal W, Chemelli RM, Miller MS, Scammell TE, Yanagisawa M, Sinton CM. Modafinil more effectively induces wakefulness in orexin-null mice than in wild-type littermates. Neuroscience. 2005; 130:983-995. [PubMed: 15652995]

Willie JT, Takahira H, Shibahara M, Hara J, Nomiyama M, Yanagisawa M, Sakurai T. Ectopic overexpression of orexin alters sleep/wakefulness states and muscle tone regulation during REM sleep in mice. J. Mol. Neurosci. 2011; 43:155-161. [PubMed: 20711757]

Winstone AM, Stellitano L, Verity C, Andrews N, Miller E, Stowe J, Shneerson J. Clinical features of narcolepsy in children vaccinated with AS03 adjuvanted pandemic A/H1N1 2009 influenza vaccine in England. Dev. Med. Child Neurol. 2014; 56:1117-1123. [PubMed: 25041214]

Wisor J. Modafinil as a catecholaminergic agent: empirical evidence and unanswered questions. Front. Neurol. 2013; 4:139. [PubMed: 24109471]

Wisor JP, Nishino S, Sora I, Uhl GH, Mignot E, Edgar DM. Dopaminergic role in stimulant-induced wakefulness. J. Neurosci. 2001; 21:1787-1794. [PubMed: 11222668]

Wu MF, Gulyani SA, Yau E, Mignot E, Phan B, Siegel JM. Locus coeruleus neurons: cessation of activity during cataplexy. Neuroscience. 1999; 91:1389-1399. [PubMed: 10391445]

Xie X, Smart TG. Gamma-hydroxybutyrate hyperpolarizes hippocampal neurones by activating GABAB receptors. Eur. J. Pharmacol. 1992; 212:291-294. [PubMed: 1318216]

Xyrem $^{\circledR}$. Xyrem(R) (sodium oxybate oral solution) Prescribing Information [Package Insert]. Jazz Pharmaceuticals, Inc.; Palo Alto, CA: 2005.

Yamanaka A, Muraki Y, Tsujino N, Goto K, Sakurai T. Regulation of orexin neurons by the monoaminergic and cholinergic systems. Biochem. Biophys. Res. Commun. 2003; 303:120-129. [PubMed: 12646175]

Yamuy J, Fung SJ, Xi M, Chase MH. Hypocretinergic control of spinal cord motoneurons. J. Neurosci. 2004; 24:5336-5345. [PubMed: 15190106]

Yin J, Mobarec JC, Kolb P, Rosenbaum DM. Crystal structure of the human OX2 orexin receptor bound to the insomnia drug suvorexant. Nature. 2015; 519:247-250. [PubMed: 25533960] 
Yoss RE, Daly DD. Criteria for the diagnosis of the narcoleptic syndrome. Proc. Staff Meet. Mayo Clin. 1957; 32:320-328. [PubMed: 13441766]

Young JW, Geyer MA. Action of modafinil-increased motivation via the dopamine transporter inhibition and D1 receptors? Biol. Psychiatry. 2010; 67:784-787. [PubMed: 20132929]

Zhang S, Lin L, Kaur S, Thankachan S, Blanco-Centurion C, Yanagisawa M, Mignot E, Shiromani PJ. The development of hypocretin (orexin) deficiency in hypocretin/ataxin-3 transgenic rats. Neuroscience. 2007; 148:34-43. [PubMed: 17618058]

Zolkowska D, Jain R, Rothman RB, Partilla JS, Roth BL, Setola V, Prisinzano TE, Baumann MH. Evidence for the involvement of dopamine transporters in behavioral stimulant effects of modafinil. J. Pharmacol. Exp. Ther. 2009; 329:738-746. [PubMed: 19197004] 

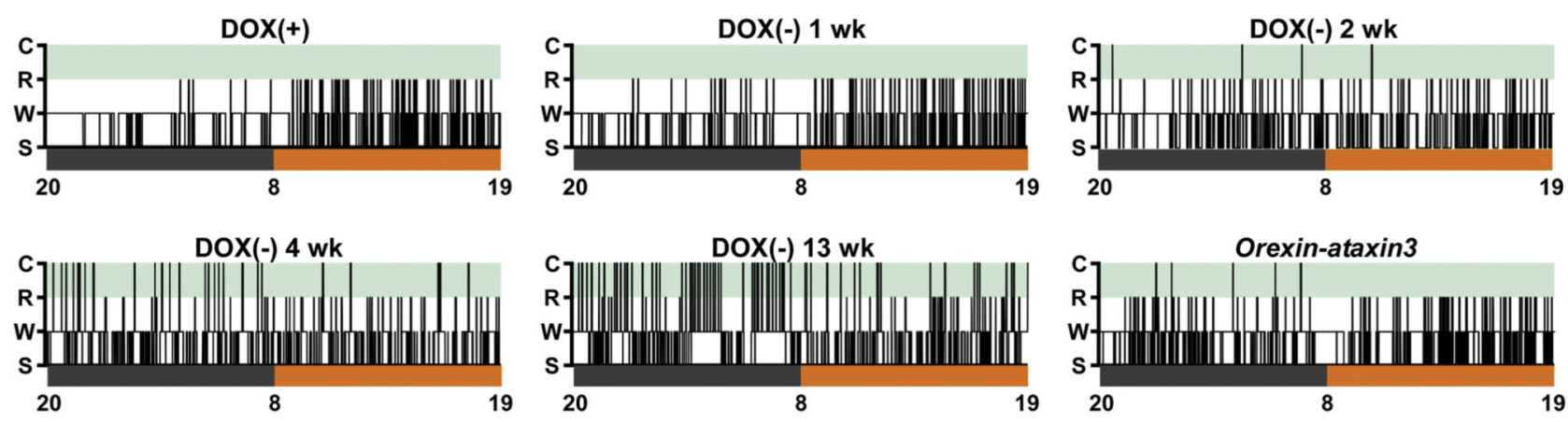

Fig. 1.

Hypnograms depicting arousal state (C, cataplexy; R, REM sleep; W, wakefulness; S, NREM sleep) changes over time in a representative orexin/tTA; TetO diphtheria toxin (DTA) mouse before hypocretin neuron ablation, while maintained on doxycycline chow (DOX $(+))$, and 1, 2, 4 and 13 weeks (wk) after return to standard mouse chow (DOX $(-)$ ) in comparison to an orexin-ataxin 3 mouse. Hypnograms are plotted for $24 \mathrm{~h}$ beginning at lights off at 20:00, with the $12 \mathrm{~h}$ dark period in black and $12 \mathrm{~h}$ light period in orange. Sleep/wake fragmentation occurred within 1 wk after DOX(-) and progressively worsened throughout the recording period. Cataplexy appeared after 2 wks DOX $(-)$, at which point arousal states resembled those of the orexin-ataxin 3 mouse. Cataplexy was highly enriched at $13 \mathrm{wks}$ $\operatorname{DOX}(-)$ when compared to earlier ages and to the orexin-ataxin3 mouse. 


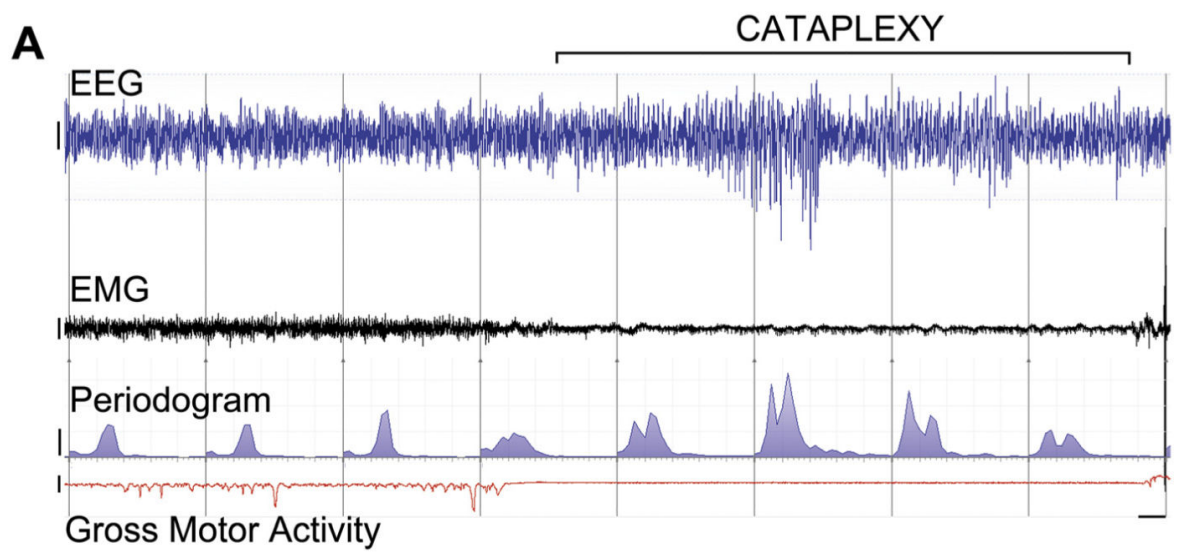

B
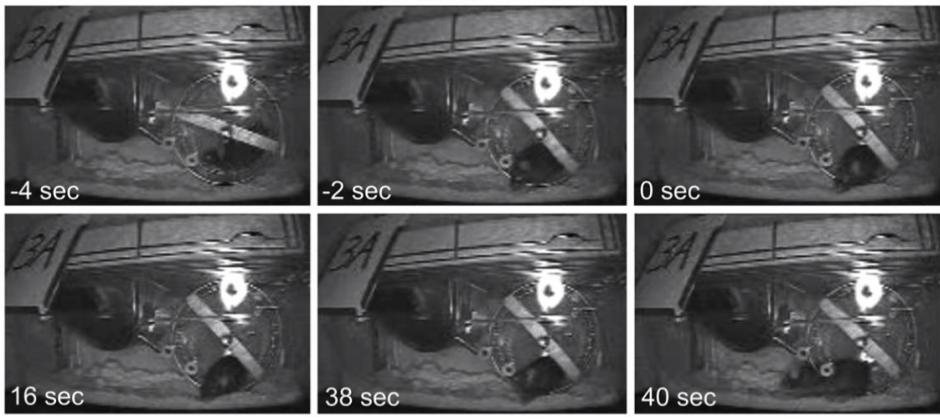

Fig. 2.

Electrophysiological and behavioral indices of cataplexy in a representative DTA mouse at 9 weeks DOX(-). (A) $80 \mathrm{~s}$ recording (demarcated in $10 \mathrm{~s}$ epochs by vertical lines) shows $\sim 40$ s cataplexy episode (bracket) and prior wakefulness with wheel-running activity revealed by EEG (blue), EMG (black), EEG periodogram (blue area under curve, 0-25 Hz), and gross motor activity (red, as inferred by telemetry unit signal strength). (B) Frames from video in the seconds before cataplexy onset, at onset and during the bout of cataplexy, and $2 \mathrm{~s}$ after cataplexy termination. Bars $=200 \mu \mathrm{V}$ (EEG and EMG), $200 \mu \mathrm{V}^{2}$ (EEG periodogram), and 5 arbitrary units (signal strength measure of gross motor activity). 


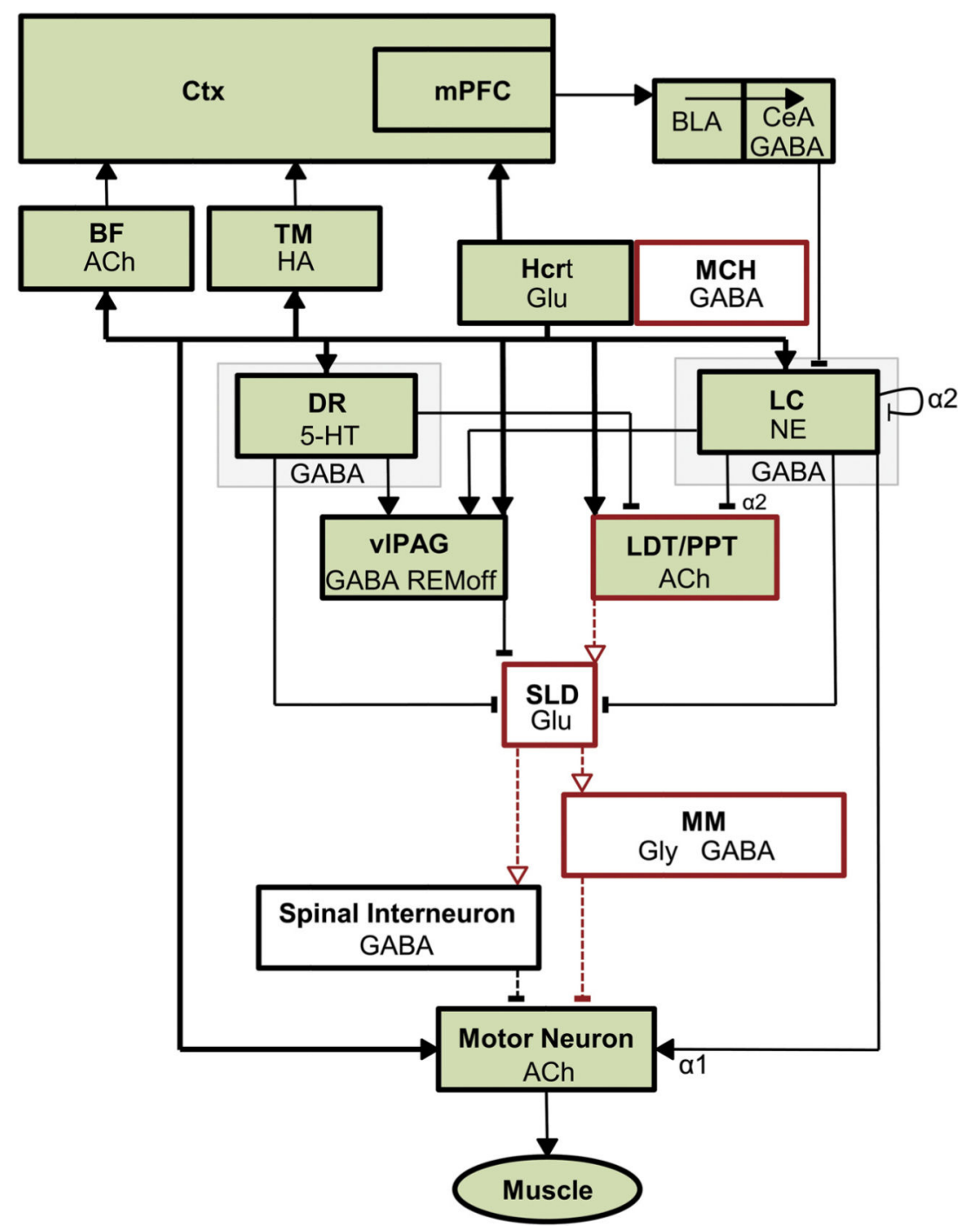

Fig. 3.

Schematic illustrating the brain regions currently known to be involved in the control of wakefulness and muscle tone. Neuronal populations that are active during wakefulness (green) consist of hypocretin neurons (Hcrt) that project most densely and provide excitatory input (solid arrowheads) to the locus coeruleus (LC) and other wake-promoting areas: the basal forebrain $(\mathrm{BF})$, tuberomamillary nucleus (TM), dorsal raphe (DR), laterodorsal and pedunculopontine tegmental nuclei (LDT/PPT), ventrolateral periaqueductal gray (vlPAG), and directly to cortex and spinal motor neurons. Hcrt neurons also increase motor tone through suppression of REM sleep atonia circuitry, which consists of sublaterodorsal nucleus (SLD) excitation of medial medulla (MM) and spinal interneurons that inhibit motor neurons. Active inhibition of atonia circuitry is mediated by HCRT excitation of monoaminergic and GABAergic pathways that inhibit (blunt terminals) the SLD. Disinhibition of REM sleep atonia circuitry during wakefulness may underlie cataplexy in narcolepsy (see Fig. 4). Key: solid lines/arrows, active excitation; solid lines/blunt terminals, active inhibition; dashed lines/arrows, disfacilitation; dashed lines/blunt terminals, 
disinhibition; thick black lines, Hcrt projections; red, neurons and pathways that are active in REM sleep; REMoff, neurons that are silent in REM sleep; Ctx, Cerebral cortex; mPFC, medial prefrontal cortex; BLA, basolateral amygdala; CeA, central nucleus of the amygdala; $\mathrm{MCH}$, melanin-concentrating hormone cells; ACh, acetylcholine; HA, histamine; Glu, glutamate; GABA, gamma-aminobutyric acid; Gly, glycine; 5-HT, serotonin; NE, norepinephrine; $a 2$, noradrenergic autoreceptor; $a 1$, noradrenergic a 1 receptor. 


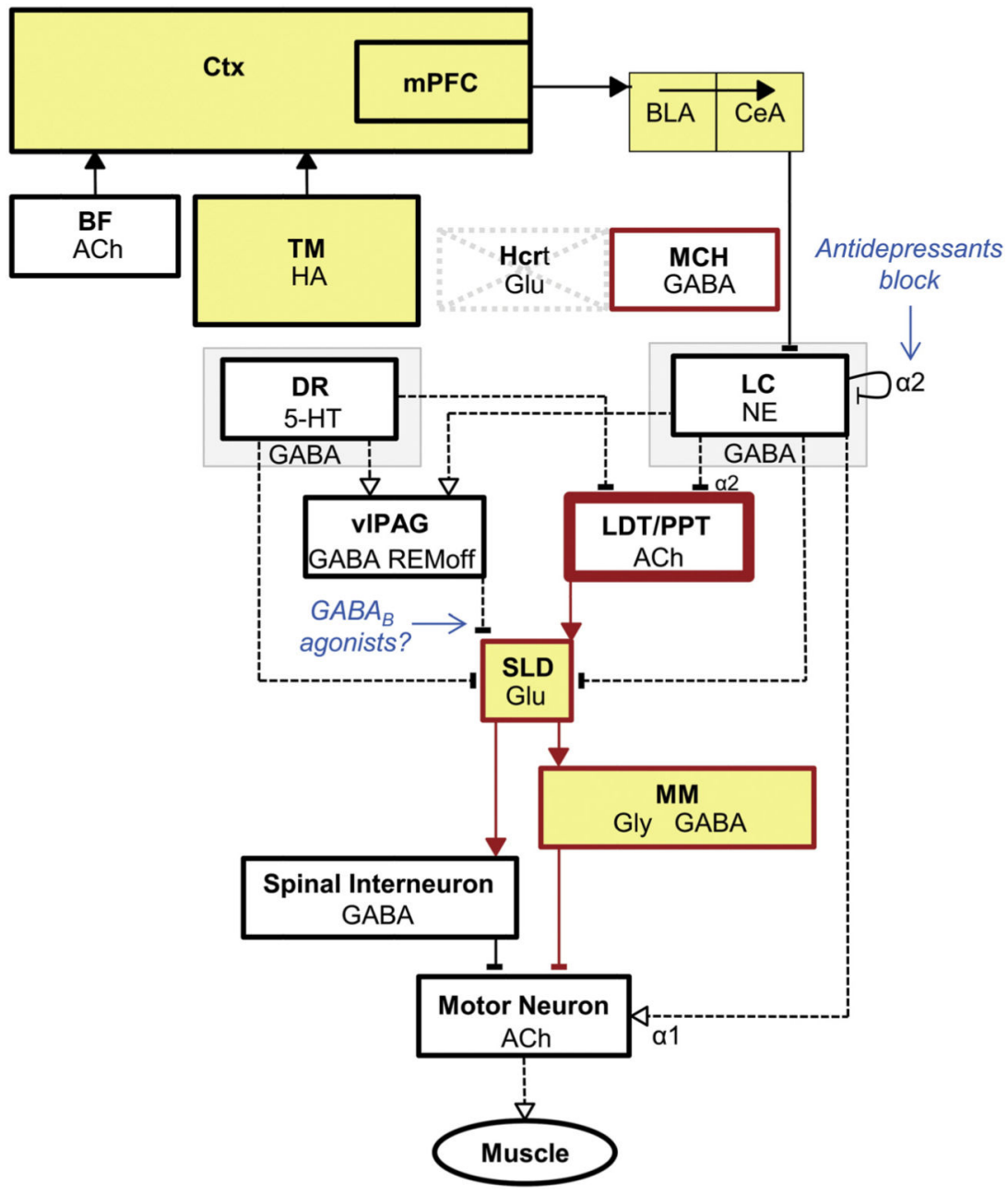

Fig. 4.

Schematic illustrating arousal-state circuitry in narcolepsy and cataplexy. Hypocretin (Hcrt) neurons and their projections to wake-promoting regions (see Fig. 3) are absent in narcolepsy. Presumably as a compensatory consequence, pontine cholinergic supersensitivity (thick lined box), monoaminergic hypoactivity in the amygdala (thin lined boxes) and increased numbers of HA neurons develop. Neuronal populations that are active during cataplexy (yellow) include regions that are also active during wakefulness and REM sleep. Cataplexy can be triggered by positive emotional stimuli that activate neurons in the $\mathrm{mPFC}$ and amygdala, which then may disinhibit REM sleep atonia circuitry. In individuals without narcolepsy, HCRT excitation onto LC neurons could balance the GABAergic inhibition from CeA to maintain normal muscle tone. Activation of the atonia circuitry is mediated by withdrawal of GABAergic inhibition of SLD neurons from the vIPAG and monoaminergic inhibition from the DR and LC. Direct activation of SLD neurons could result from upregulated cholinergic mechanisms in the LDT/PPT. Cataplexy can be alleviated by antidepressants that increase noradrenergic tone via blockade of a 2 autoreceptors; mechanisms of $\mathrm{GABA}_{\mathrm{B}}$ therapeutics for cataplexy are unknown, but may involve inhibition of SLD neurons to suppress atonia. Key: see Fig. 3. 

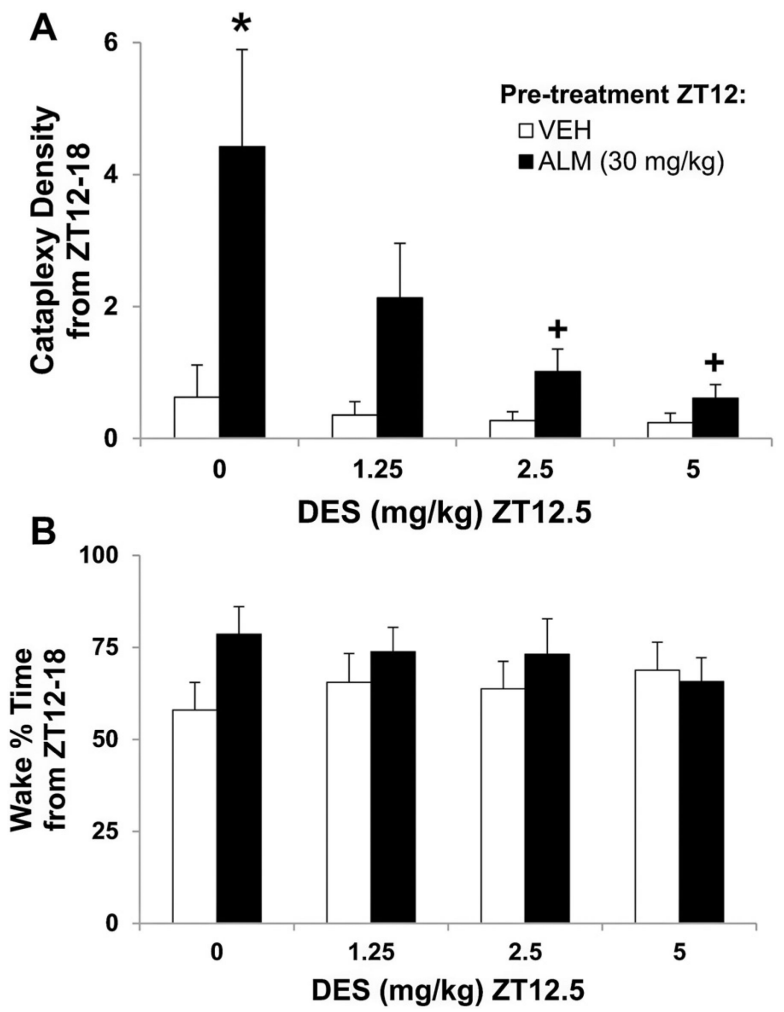

Fig. 5.

The narcolepsy/cataplexy assay for orexin/ataxin-3 transgenic mice. (A) Cataplexy density (the number of cataplexy bouts per time awake) and (B) percent time awake during the $6 \mathrm{~h}$ following pretreatment with almorexant (ALM, black) vs. vehicle (VEH, white) at ZT12 and treatment with desipramine (DES 0-5 mg/kg) $30 \mathrm{~min}$ later. Two-way repeated measures ANOVA: $* p<0.05$ vs. VEH pretreatment, ${ }^{*} p<0.05$ vs. DES $(0 \mathrm{mg} / \mathrm{kg}) ; n=4$. 
Table 1

Rodent models of narcolepsy, hypocretin dysfunction or transgenic tools.

\begin{tabular}{|c|c|c|c|}
\hline Strain \& alternative names & Structural mutation & Phenotype & Reference \\
\hline \multicolumn{4}{|l|}{ Mouse } \\
\hline Prepro-orexin knockout; orexin ${ }^{-/-}$ & $\begin{array}{l}\text { Constitutively absent Hcrt precursor } \\
\text { gene }\end{array}$ & $\begin{array}{l}\text { Sleep/wake fragmentation, } \\
\text { reduced REM onset, increased } \\
\text { REM time, decreased wake during } \\
\text { dark period, frequent cataplexy; } \\
\text { obesity }\end{array}$ & $\begin{array}{l}\text { Chemelli et al. } \\
\text { (1999); Mochizuki et } \\
\text { al. (2004) }\end{array}$ \\
\hline HcrtR1 knockout; $O X_{1} R^{-/-}$ & Constitutively absent HcrtR1 & $\begin{array}{l}\text { Mild sleep/wake fragmentation, } \\
\text { no cataplexy }\end{array}$ & Kisanuki et al. (2001) \\
\hline$H c r t R 2$ knockout; $\mathrm{OX}_{2} R^{-/-}$ & Constitutively absent HcrtR2 & $\begin{array}{l}\text { Mild sleep/wake fragmentation, } \\
\text { sleep attacks, mild cataplexy }\end{array}$ & Willie et al. (2003) \\
\hline $\begin{array}{l}\text { HcrtR1 \& HcrtR2 double knockout; } \\
O X_{1} R^{-/-} / \mathrm{OX}_{2} R^{-/-}\end{array}$ & $\begin{array}{l}\text { Constitutively absent HcrtR } 1 \text { and } \\
\text { HcrtR2 }\end{array}$ & $\begin{array}{l}\text { Sleep/wake fragmentation, } \\
\text { reduced REM onset, increase } \\
\text { REM time, decreased wake during } \\
\text { dark period, cataplexy }\end{array}$ & $\begin{array}{l}\text { Kisanuki et al. } \\
(2001) \text {; Kalogiannis } \\
\text { et al. (2011) }\end{array}$ \\
\hline Orexin/ataxin-3 transgenic, Ataxin & Postnatal Hcrt neuron ablation & $\begin{array}{l}\text { Sleep/wake fragmentation, } \\
\text { reduced REM onset, increased } \\
\text { REM time, decreased wake during } \\
\text { dark period, variable cataplexy; } \\
\text { obesity }\end{array}$ & Hara et al. (2001) \\
\hline Orexin/eGFP transgenic & $\begin{array}{l}\text { eGFP reporter driven by Hcrt } \\
\text { promoter }\end{array}$ & $\begin{array}{l}\text { None; permits visualization of } \\
\text { Hcrt cells }\end{array}$ & $\begin{array}{l}\text { Yamanaka et al. } \\
(2003) \text {; Muraki et al. } \\
(2004)\end{array}$ \\
\hline Prepro-Hcrt overexpressor & $\begin{array}{l}\text { Constitutive overexpression of } \\
\text { prepro-orexin, decreased HcrtR } 2 \text { in } \\
\text { hypothalamus }\end{array}$ & $\begin{array}{l}\text { Small decrease in REM during } \\
\text { recovery from sleep deprivation }\end{array}$ & Makela et al. (2010) \\
\hline O/E3 null mutant & $\begin{array}{l}\text { Constitutively absent helix-loop-helix } \\
\text { transcription factor, decreased Hcrt } \\
\text { cell number }\end{array}$ & $\begin{array}{l}\text { Sleep/wake fragmentation, } \\
\text { reduced REM onset, increased } \\
\text { REM time, decreased wake during } \\
\text { dark period, cataplexy }\end{array}$ & $\begin{array}{l}\text { De la Herran-Arita et } \\
\text { al. (2011) }\end{array}$ \\
\hline Orexin/Halo transgenic & Halorhodopsin expressed in Hcrt cells & $\begin{array}{l}\text { None; permits inhibition of Hcrt } \\
\text { cells }\end{array}$ & $\begin{array}{l}\text { Tsunematsu et al. } \\
\text { (2011) }\end{array}$ \\
\hline $\begin{array}{l}\text { Orexin/tTA;TetO Chr2 (C128S) double } \\
\text { transgenic }\end{array}$ & $\begin{array}{l}\text { Conditional step-function opsin } \\
\text { expression in Hcrt cells }\end{array}$ & $\begin{array}{l}\text { None; permits widespread } \\
\text { expression of ChR2 in Hcrt cells } \\
\text { under Dox(-) control \& excitation } \\
\text { of Hcrt cells }\end{array}$ & Tanaka et al. (2012) \\
\hline $\begin{array}{l}\text { Orexin/tTA;TetO ArchT double } \\
\text { transgenic }\end{array}$ & $\begin{array}{l}\text { Conditional archaerodopsin } \\
\text { expression in Hcrt cells }\end{array}$ & $\begin{array}{l}\text { Unknown; permits wide-spread } \\
\text { expression under Dox(-) control \& } \\
\text { inhibition of Hcrt cells }\end{array}$ & $\begin{array}{l}\text { Tsunematsu et al. } \\
\text { (2013) }\end{array}$ \\
\hline$O X / t T A$ transgenic & $\begin{array}{l}\text { Tetracycline transactivator driven by } \\
\text { Hcrt promoter }\end{array}$ & $\begin{array}{l}\text { None; useful with Tet-on or Tet- } \\
\text { off expression systems, or opsins } \\
\text { through breeding or viral delivery }\end{array}$ & $\begin{array}{l}\text { Tsunematsu et al. } \\
\text { (2013) }\end{array}$ \\
\hline $\begin{array}{l}\text { Orexin/tTA;TetO DTA double } \\
\text { transgenic, DTA }\end{array}$ & Conditional Hcrt neuron ablation & $\begin{array}{l}\text { Extreme sleep/wake } \\
\text { fragmentation, reduced REM } \\
\text { onset, increased REM time, } \\
\text { decreased wake during dark } \\
\text { period, extreme cataplexy; obesity }\end{array}$ & Tabuchi et al. (2014) \\
\hline$O X I R /$ eGFP transgenic & $\begin{array}{l}\text { eGFP reporter driven by first coding } \\
\text { exon of Hcrtr } 1 \text { gene }\end{array}$ & $\begin{array}{l}\text { None; permits visualization of } \\
\text { cells that express Hcrtr1 }\end{array}$ & $\begin{array}{l}\text { Darwinkel et al. } \\
\text { (2014); Ch'ng and } \\
\text { Lawrence (2015) }\end{array}$ \\
\hline \multicolumn{4}{|l|}{ Rat } \\
\hline Hcrt2-saporin conjugate & $\begin{array}{l}\text { Ablation of Hcrt, MCH and ADA } \\
\text { cells }\end{array}$ & $\begin{array}{l}\text { Sleep/wake fragmentation, } \\
\text { reduced REM onset, increased } \\
\text { REM time, decreased wake during } \\
\text { dark period, cataplexy, attenuated } \\
\text { sleep/wake circadian rhythm }\end{array}$ & $\begin{array}{l}\text { Gerashchenko et al. } \\
\text { (2001) }\end{array}$ \\
\hline
\end{tabular}




\begin{tabular}{llll}
\hline Strain \& alternative names & Structural mutation & Phenotype & Reference \\
\hline Orexin/ataxin-3 transgenic & Postnatal Hert neuron ablation & $\begin{array}{l}\text { Sleep/wake fragmentation, } \\
\text { reduced REM onset, increased }\end{array}$ & $\begin{array}{l}\text { Beuckmann et al. } \\
\text { (2004) }\end{array}$ \\
& & $\begin{array}{l}\text { REM time, decreased wake during } \\
\text { dark period, cataplexy }\end{array}$ \\
& & late & \\
\hline
\end{tabular}


Table 2

Drugs reviewed for orphan designation for narcolepsy by the US Food and Drug Administration.

\begin{tabular}{|c|c|c|c|c|c|c|}
\hline Generic name & Trade name & Sponsor & Designation date & Orphan designation & $\begin{array}{l}\text { FDA } \\
\text { marketing } \\
\text { approval } \\
\text { date }\end{array}$ & Exclusivity end date \\
\hline Viloxazine HCL & & Stuart Pharmaceuticals & $6 / 11 / 1984$ & $\begin{array}{l}\text { Treatment of cataplexy } \\
\text { and narcolepsy }\end{array}$ & $\begin{array}{l}\text { Not FDA } \\
\text { Approved } \\
\text { for Orphan } \\
\text { Indication }\end{array}$ & NA \\
\hline Gamma-hydroxybutyric acid & & Sigma Chemical Company & $1 / 22 / 1985$ & $\begin{array}{l}\text { Treatment of narcolepsy } \\
\text { and the auxiliary } \\
\text { symptoms of cataplexy, } \\
\text { sleep paralysis, } \\
\text { hypnagogic } \\
\text { hallucinations, and } \\
\text { automatic behavior }\end{array}$ & $\begin{array}{l}\text { Not FDA } \\
\text { Approved } \\
\text { for Orphan } \\
\text { Indication }\end{array}$ & NA \\
\hline Gamma hydroxybutyrate & & Biocraft Laboratories, Inc. & $12 / 3 / 1987$ & $\begin{array}{l}\text { Treatment of narcolepsy } \\
\text { and the auxiliary } \\
\text { symptoms of cataplexy, } \\
\text { sleep paralysis, } \\
\text { hypnagogic } \\
\text { hallucinations, and } \\
\text { automatic behavior }\end{array}$ & $\begin{array}{l}\text { Not FDA } \\
\text { Approved } \\
\text { for Orphan } \\
\text { Indication }\end{array}$ & NA \\
\hline Modafinil & Provigil $^{1}$ & Cephalon, Inc. & $3 / 15 / 1993$ & $\begin{array}{l}\text { Treatment of excessive } \\
\text { daytime sleepiness in } \\
\text { narcolepsy }\end{array}$ & $12 / 24 / 1998$ & $12 / 24 / 2005$ \\
\hline Oxybate & Xyrem $^{1}$ & Jazz Pharmaceuticals & $11 / 7 / 1994$ & Treatment of narcolepsy & $11 / 18 / 2005$ & $11 / 18 / 2012$ \\
\hline BF2.649 (Pitolisant) & & Bioprojet Pharma & $5 / 17 / 2010$ & Treatment of narcolepsy & $\begin{array}{l}\text { Not FDA } \\
\text { Approved } \\
\text { for Orphan } \\
\text { Indication }\end{array}$ & NA \\
\hline $\begin{array}{l}\text { Optically pure } \\
\text { phenylalanine derivative }\end{array}$ & & $\begin{array}{l}\text { Jazz Pharmaceuticals } \\
\text { International III Limited }\end{array}$ & $8 / 20 / 2012$ & Treatment of narcolepsy & $\begin{array}{l}\text { Not FDA } \\
\text { Approved } \\
\text { for Orphan } \\
\text { Indication }\end{array}$ & NA \\
\hline
\end{tabular}

Prog Neurobiol. Author manuscript; available in PMC 2018 May 01. 